THE IMPACT OF MINIMUM AGE OF EMPLOYMENT REGULATION ON CHILD LABOR AND SCHOOLING: EVIDENCE FROM UNICEF MICS COUNTRIES

\author{
Eric V. Edmonds \\ Maheshwor Shrestha \\ Working Paper 18623 \\ http://www.nber.org/papers/w18623
NATIONAL BUREAU OF ECONOMIC RESEARCH
1050 Massachusetts Avenue \\ Cambridge, MA 02138 \\ December 2012
}

Funding for this project provided by Dartmouth College. Edmonds and Shrestha have both served as compensated consultants for international and government agencies involved in promoting minimum age of employment regulation during the period of writing this paper although their consulting did not directly relate to minimum age of employment regulation. The views expressed herein are those of the authors and do not necessarily reflect the views of the National Bureau of Economic Research.

NBER working papers are circulated for discussion and comment purposes. They have not been peerreviewed or been subject to the review by the NBER Board of Directors that accompanies official NBER publications.

(C) 2012 by Eric V. Edmonds and Maheshwor Shrestha. All rights reserved. Short sections of text, not to exceed two paragraphs, may be quoted without explicit permission provided that full credit, including (C) notice, is given to the source. 
The Impact of Minimum Age of Employment Regulation on Child Labor and Schooling: Evidence from UNICEF MICS Countries

Eric V. Edmonds and Maheshwor Shrestha

NBER Working Paper No. 18623

December 2012

JEL No. J08,J22,J24,J80

\begin{abstract}
$\underline{\text { ABSTRACT }}$
Promoting minimum age of employment regulation has been a centerpiece in child labor policy for the last 15 years. If enforced, minimum age regulation would change the age profile of paid child employment. Using micro-data from 59 mostly low-income countries, we observe that age can explain less than 1 percent of the variation in child participation in paid employment. In contrast, child-invariant household attributes account for 63 percent of the variation in participation in paid employment. While age may explain little of the variation in paid employment, minimum age of employment regulation could simultaneously impact time allocation. We do not observe evidence consistent with enforcement of minimum age regulation in any country examined, although light work regulation appears to have been enforced in one country.
\end{abstract}

Eric V. Edmonds

Department of Economics

Dartmouth College

6106 Rockefeller Hall

Hanover, NH 03755

and NBER

Eric.V.Edmonds@Dartmouth.edu

Maheshwor Shrestha

50 Memorial Drive

E52-391

Cambridge, MA 02142

mahesh68@mit.edu 


\section{The Impact of Minimum Age of Employment Regulation on Child Labor and Schooling: Evidence from UNICEF MICS Countries *}

\author{
Eric V. Edmonds \\ Dartmouth College, IZA, and NBER
}

Maheshwor Shrestha

MIT

December 2012

Promoting minimum age of employment regulation has been a centerpiece in child labor policy for the last 15 years. If enforced, minimum age regulation would change the age profile of paid child employment. Using micro-data from 59 mostly low-income countries, we observe that age can explain less than 1 percent of the variation in child participation in paid employment. In contrast, child-invariant household attributes account for 63 percent of the variation in participation in paid employment. While age may explain little of the variation in paid employment, minimum age of employment regulation could simultaneously impact time allocation. We do not observe evidence consistent with enforcement of minimum age regulation in any country examined, although light work regulation appears to have been enforced in one country.

Labor laws and regulation are the primary instruments used by many countries to combat child labor. The last 15 years has seen an enormous surge in these laws as international pressure has encouraged low income countries to sign international conventions related to the prohibition of child labor and to pass labor laws consistent with the principals of those conventions. Most countries now have laws in place that prohibit the economic activity of children below age 12 and regulate employment through age 17.

This paper considers the impact of laws that restrict the minimum age of employment on child labor and schooling. Such laws are principally directed at paid employment outside of the family. When enforced, they alter the age distribution and location of child employment. An upper bound on the importance of these laws in influence the prevalence of child labor would

\footnotetext{
"We are grateful to Doug Miller, Doug Staiger, and seminar participants at Harvard and the University of Connecticut for extremely helpful comments and to Zakariah Lakel, Meagan Morrow, Yang Wei Neo, Dana Niu, Mary Peng, Greg O'Sullivan, Niral Shah, Connie Shang, and Amy Zhang for research assistance. Edmonds and Shrestha have both served as compensated consultants for international and government agencies involved in promoting minimum age of employment regulation during the period of writing this paper although their consulting did not relate to minimum age of employment regulation directly. Correspondence to Edmonds: eedmonds@dartmouth.edu.
} 
attribute all of the age variation in work outside of the household to these laws. Of course, there are many reasons other than regulation that would lead time allocation to vary with age. Even so, using data from 59 countries included in rounds 2 and 3 of UNICEF's Multiple Indicator Cluster Survey, we observe that age accounts for little of the variation in paid employment outside of the home, schooling, or idleness. ${ }^{1}$ For example, age explains less than 0.5 percent of the variation in paid employment in the 29 African countries examined herein. The largest share of the variation in paid employment explained by age in Africa is 1.6 percent in Madagascar, where compulsory schooling and minimum age of employment regulations relax at the same age. In contrast, household characteristics such as income and parental background account for 67 percent of the variation in paid employment in our African data and 63 percent across all countries. These findings are consistent with the literature from high income countries that document an impact of minimum age of employment regulation and compulsory schooling laws on education but find the impact of these law changes to be modest compared to the secular trends (Moehling 1999, Lleras-Muney 2001, Goldin and Katz 2003).

Age may account for little of the variation in paid employment, but there is still scope for minimum age of employment regulation to influence time allocation. To examine this, we look for changes in time allocation at the minimum age of employment in each of the 59 countries separately and pooled. Our econometric approach is to compare the observed prevalence of paid employment at the minimum age of employment to what would be predicted based on an age trend estimated on the regulated (younger) ages. Our estimates of the impact of minimum age regulation are, in effect, estimates of the impact on paid employment of extending current minimum age regulations by one additional year, holding all prices fixed. Of course, this design does not inform the counterfactual of what employment would be in the absence of minimum age laws altogether.

In the pooled and weighted data from all 59 countries representing 158 million children, we find that paid employment increases by a statistically insignificant 0.7 percentage points, or 11 percent, at the minimum age of employment. When we look at each country separately as well as at all the different measures of time allocation available in our data, we are plagued by

\footnotetext{
${ }^{1}$ Idleness is defined as not attending school while not working or participating in household based activities, including chores. All analysis of variance is based on a model regressing paid employment, household fixed effects, age effects, and gender for households with more than 1 child 8-14 present. Thus, all discussion of the explanatory power of age is based on the partial R2 attributable to age in the model.
} 
the multiple hypothesis problem and type I errors. We rely on economic theory to assess whether statistically significant changes stem from minimum age regulation. In the presence of competitive labor markets and working capital within the household, we show that binding minimum age of employment regulations shift child work to the family farm or business but have no effect on schooling. Our argument is based on three assumptions. First, child and adult labor are perfect substitutes subject to a productivity shifter ("the substitution axiom" in Basu and Van 1998). Second, the child's household can freely substitute adult and child labor between productive tasks inside the household, i.e. "non-saturation." Third, adult labor can move freely between the household and the labor market, i.e. "competitive adult labor markets".

According to this theory, the data will be consistent with binding minimum age of employment regulation when we observe increases in paid employment, decreases in work inside the household, and no change in schooling or idleness at the minimum age of employment. In the data, we observe increases in paid employment at the minimum age only in 4 of the 59 countries. We do not observe a significant or substantive decline in work inside the family at the minimum age in any of the countries. Hence, we do not observe evidence consistent with binding minimum age of employment regulation in a single country. The data are consistent with increases in household based activities when paid employment increases in general. Some countries have labor laws that allow light work before the minimum age of employment, and there is one country, Trinidad and Tobago, where the data are consistent with binding light work regulations.

Compulsory schooling regulation, which co-exists with minimum age regulation in many countries, presents both an econometric and interpretive problem in our results. When both regulations relax at the same time, we will not be able to attribute the changes in child time allocation to one particular regulation. On the other hand, if compulsory schooling law relaxes at a younger age than the minimum age of employment, then it creates a distortion in the age profile of child time allocation. This is problematic as we use age trends in child time allocation to estimate the counterfactual allocation at the minimum age of employment. We find evidence consistent with binding compulsory schooling regulations in one country, Burundi, where the law may interfere with our ability to infer whether minimum age regulations bind.

There are 17 countries in our data where the minimum age of employment is the same as the age at which schooling is no longer compulsory. In 4 of these countries we observe increases in paid employment at the minimum age but also observe increases in household based 
employment (inconsistent with binding minimum age of employment regulation). It is possible that these findings are driven by a combination of minimum age of employment regulation and compulsory schooling laws (although the change in schooling is not significant in any of the four). In fact, we find that the changes in paid employment are 9 times larger in magnitude in the pooled data in the selected group of countries where minimum age of employment and compulsory schooling regulations coincide compared to countries where schooling is not compulsory at the minimum age of employment. Hence, while overall, we find little empirical evidence to suggest an impact of minimum age of employment regulation, as enforced, on child labor, there may be some benefit to coordinating employment and schooling regulation. That said, given the importance of household-level, child-invariant characteristics in child labor, it is not obvious why age-based regulation, as currently implemented and enforced, has its current place at the center of anti-child labor policy.

In the next section of the paper, we present an overview of minimum age of employment regulation in our data. Section II considers how binding minimum age of employment regulation influences time allocation. Section III describes our empirical approach to measure the impact of minimum age regulation and the data we use. Section IV presents our findings. Section V concludes.

\section{Background on Minimum Age of Employment Regulation}

Minimum age of employment regulations have existed in many high income countries since the late nineteenth century, and a series of international, industry specific minimum age of employment conventions were passed in the 1920s and 30s. The minimum age regulations studied herein have been influenced by two more recent international conventions.

ILO Convention 138 on the Minimum Age for Admission to Employment was passed on June 26, 1973 and has been ratified by 161 countries at the time of writing. A majority of ratifying countries have done so subsequent to 1996 . While there is considerable nuance in C138, three broad ideas in $\mathrm{C} 138$ are especially important in our discussion. ${ }^{2}$ First, $\mathrm{C} 138$ emphasizes that countries should raise the minimum age of admission to employment to no less than 15 . Countries that are "insufficiently developed" may specify a transitional minimum age of employment of 14. Second, it distinguishes between employment and light work, defining

\footnotetext{
${ }^{2} \mathrm{C} 138$ can be read at http://www.ilo.org/ilolex/cgi-lex/convde.pl?C138.
} 
neither. Light work is codified on a national basis, but in principal it is work that does not conflict with school attendance and is not harmful to child health. Light work may be permissible from age 13. Third, it explicitly excludes "family and small-scale holdings producing for local consumption and not regularly employing hired workers" (article 5 section 3 ) from the provisions of the convention.

ILO Convention 182 on the Prohibition and Immediate Action for the Elimination of the Worst Forms of Child Labor on was passed on June 17, 1999 and has been ratified by 174 countries at the time of writing. ${ }^{3} \mathrm{C} 182$ defines a child as a person under 18 and proposes restrictions on certain categories of employment until age 18. It differentiates between unconditional worst forms of child labor from which children should be prohibited regardless of circumstance (includes all forms of modern slavery, prostitution and pornography, illicit activities and drug trade, and armed conflict) and hazardous child labor that national laws must define.

This paper examines the impact of minimum age of employment laws in all 59 countries with publicly available time allocation data from the second and third rounds of UNICEF's Multiple Indicator Cluster Surveys (MICS). ${ }^{4}$ Data collection instructions and survey questions are nearly uniform across each MICS country allowing for cross-country comparisons. Round 2 of MICS occurred in 2000/01. Round 3 occurred 05/06. In the public use data, there are 28 African countries, 14 from Europe and Central Asia, 7 from East Asia and the Pacific, 6 from Latin American and the Caribbean, 3 from Middle East and North Africa, and 1 from South Asia. Nineteen countries have data in both MICS 2 and 3. The remaining 40 countries only have surveys in 1 of the 2 rounds.

In reviewing the minimum age of employment regulation in these MICS2 and MICS3 countries, their legislation generally looked like a combination of these principles from the two conventions. Most countries have some form of light work allowable at some age under 14, a general easing of restrictions on most forms of employment around 14 of 15 , and continued regulation on certain types of work until age 18 . We define the minimum age of employment as the youngest age at which it is legal to pay a child to work full time outside the home (during the

\footnotetext{
${ }^{3} \mathrm{C} 182$ is available from http://www.ilo.org/ilolex/cgi-lex/convde.pl?C182.

${ }^{4}$ The data are available from http://www.childinfo.org/. A few countries in the publicly available data have been excluded from our study, because they did not execute the child labor module.
} 
day, limited hours). We define the light work age as the youngest age at which a child may work for limited hours during the day in traditional (a common word) or family based activities.

Table 1 summarizes the regulation for light work and non-hazardous work for the countries considered in this study. When countries appear in both MICS2 and MICS3, they are listed once if minimum age regulations did not change substantively between rounds, and they are listed twice if their regulations changed. We report the minimum age of employment regulations in place at the time of the survey. Of the countries surveyed in both MICS2 and MICS3, only Gambia and Trinidad and Tobago have changed the basic minimum age of employment for non-hazardous work.

Fourteen is the modal minimum age of employment. Only Somalia does not appear to have any non-hazardous work regulation in place at the time of MICS3. Nineteen countries distinguish between light work and non-hazardous work, so the two ages are the same for a majority of the countries. Appendix 1 contains full country-by-country detail on how minimum ages were coded with detailed information for each country. Many countries contain exceptions from regulations for apprentices and work done in school, and we have coded the minimum ages in the table excluding apprenticeship regulation and allowances of work done in school.

An important issue that will arise in assessing the impact of the minimum age of employment regulation is whether the laws co-move with compulsory schooling regulation or natural school transition points. C138 stipulates that compulsory schooling laws should define the lower bound on minimum age of employment regulation if such laws require schooling beyond age 14. The last column of Table 1 contains the age at which schooling is no longer compulsory (or NA if schooling is not compulsory). Compulsory schooling regulations are sometimes based on grade completion, in which case we have translated that grade to an age using the rates of school completion reported by UNESCO (see the appendix). These imputed compulsory schooling ages are marked with an asterisk. Four countries do not have any compulsory schooling regulation. Sixteen of the 59 countries have aligned their compulsory schooling laws with their minimum age of employment laws. The next section considers how these minimum age of employment regulations and compulsory schooling laws impact time allocation. 


\section{Theory - The Impact of Binding Constraints on Employment Outside the Home}

C138 explicitly excludes work inside the family from minimum age of employment regulation. Many countries have regulations that cover work inside the home, but even when it is law, few countries (high or low income) discuss enforcement of labor regulation inside the family. Hence, we treat enforced minimum age of employment regulation as affecting the availability of employment outside of the household. We begin with an unconstrained (separable) farm household model as a benchmark. We add binding constraints on employment outside of the home in section B. A challenge in our empirical work below is disentangling the effects of minimum age of employment regulation from compulsory schooling laws. We consider how the two-child time allocation related laws differ in their effects in section C.

\section{A. Unconstrained Model}

We begin with a standard separable farm household model (e.g. Benjamin 1992) and add children and child labor. ${ }^{5}$ We adopt two modeling simplifications standard in the child labor literature (e.g. Basu and Van 1998). A family consists of one child and one adult. Adults and children are perfect substitutes in production subject to a productivity shifter. A child is equivalent to $a$ adults, where $a<1$. This is known as the substitution axiom. We begin with the unrestricted case of perfectly competitive labor markets where adults and children can freely sell their labor in the open labor market. Adult labor receives a wage $w$. Children then receive the wage $a w$.

Preferences are defined over the family's standard of living $s$, the child's education $e$, and the adult's and the child's leisure consumption, $\left\{l^{A}, l^{C}\right\}$ respectively, with the utility representation:

$$
U\left(s, e, l^{A}, l^{C}\right)
$$

Returns to education are understood to be part of the agent's utility from education. Education costs $p$ per unit. Total expenditures on education and the standard of living (price=1) come from net income from the family business and labor income:

$$
s+p e=F\left(L_{H}^{O}+L_{H}^{A}+a L_{H}^{C}\right)-w L_{H}^{O}+w L_{M}^{A}+a w L_{M}^{C}
$$

\footnotetext{
${ }^{5}$ Most working children do so inside their household. In our data, children are 9 times more likely to work in the family farm or business than in paid employment. We think it is reasonable to suppose that the typical household in our data has some sort of farm or home enterprise in which children may participate.
} 
where $\left\{L_{H}^{O}, L_{H}^{A}, L_{H}^{C}\right\}$ respectively are the use of outside adult equivalent, adult, and child labor in the family business. F(-) is the household's production function (expressed in the same units as $s$ ) and exhibits a positive, diminishing marginal product. For economy, we have suppressed other inputs in the production function. Adult and child employment in the labor market are defined as $\left\{L_{M}^{A}, L_{M}^{C}\right\}$. Without constraints on the allocation of child time, the child and adult time endowments are:

$$
L_{M}^{C}+L_{H}^{C}+l^{C}=E^{C}-e
$$

and

$$
L_{M}^{A}+L_{H}^{A}+l^{A}=E^{A} .
$$

Substituting (3) and (4) into (2), we have the full income constraint of the unrestricted model:

$$
s+w l^{A}+a w l^{C}+(p+a w) e=\Pi(w)+w E^{A}+a w E^{C}
$$

with

$$
\Pi(w)=F\left(L_{H}^{O}+L_{H}^{A}+a L_{H}^{C}\right)-w L_{H}^{O}-w L_{H}^{A}-a w L_{H}^{C} .
$$

The family allocates child time between types of employment so that the value of the child's marginal product in the home enterprise is equal to its price in the local labor market. Child leisure consumption and thus schooling is chosen so that the marginal rate of substitution between leisure and standard of living depends on the child's wage (aw):

$$
\frac{\partial u / \partial l^{C}}{\partial u / \partial s}=a w
$$

and the allocation of child time between leisure and schooling depends on the relative cost of schooling, which is:

$$
\frac{\partial u / \partial l^{C}}{\partial u / \partial e}=\frac{a w}{p+a w}
$$

Household demand functions for education and leisure then depend on child wages, the price of schooling and endowment incomes:

$$
k=D^{k}\left(p+a w, a w, \Pi^{*}(w)+w E^{A}+a w E^{C}\right), k \in\left\{e, l^{c}\right\} .
$$

where $\Pi *(w)=\max _{L_{H}^{O}, L_{H}^{A}, L_{H}^{C}} F\left(L_{H}^{O}+L_{H}^{A}+a L_{H}^{C}\right)-w L_{H}^{O}-w L_{H}^{A}-a w L_{H}^{C}$. 


\section{B. Binding Minimum Age of Employment}

We assume minimum age of employment laws regulate child employment outside of the household. Consider a country with binding minimum age of employment laws that reduce child employment outside the household. Binding minimum age regulation does not affect the total amount the child works or the child's leisure consumption and schooling under the assumption of non-saturation. That is, so long as families have productive opportunities for labor inside the household, binding minimum age regulations change the location of work but not the amount of work.

To see that binding minimum age regulation induces substitution between activities, suppose that the binding constraint on work outside of the household adds the restriction of $L_{M}^{C}=0$ (3). This has no effect on the opportunity cost of child leisure in the household so long as there is some adult (hired in or own) labor in the family enterprise. ${ }^{6}$ The key reason why minimum age restrictions do not impact schooling or work probabilities (only type of work) is that households are free to buy and sell other forms of labor. Faced with additional child labor in the family business, the household reduces its use of hired in and adult labor until the value of adult equivalent labor's marginal product equals the market wage. The value of adult equivalent labor in the family business will still be equal to the market wage. Hence, the value of the child's marginal product of labor is still $a w$. This produces the same marginal rate of substitution between leisure and standard of living as in equation (7).

It is possible that constraining all child labor to the family business reduces productivity in the family business to below the market wage and no adults would participate. We call this the "saturation" case. It is unclear how schooling and leisure consumption should change when binding constraints on paid employment induce saturation. Child productivity in the family enterprise is below what it was in the unconstrained case $\left(a F^{\prime}<a w\right)$. Household income declines. The opportunity cost of time in leisure is the agent's value of the child's productivity in the farm $(\partial u / \partial s) a F^{\prime}$, and whether it is above or below the opportunity cost of time in leisure in the unconstrained case depends on the curvature in preferences for $s$. However, we should see a

\footnotetext{
${ }^{6}$ If there is no adult labor market and no child labor market, then there is no labor market in which to regulate the child's participation. Hence, the premise of minimum age regulation on employment outside of the child's home is that there is some functioning labor market present.
} 
rise in household-based economic activity and specialization of adult employment towards work outside the home with saturation.

We are skeptical about the relevance of saturation for our analysis. What keeps the household from starting multiple businesses if the marginal product of labor in one is below market? Banerjee and Duflo (2007) document the prevalence of multiple enterprises within nonfarm households, and the diversity of activities within farm households is broadly understood. We interpret this lack of specialization as being consistent with our hypothesis that even poor households can create multiple enterprises rather than face saturation in within-household labor supply.

\section{Binding Compulsory Schooling Laws}

Binding compulsory schooling laws may be de facto or de jure. De facto compulsory schooling laws occur when strong norms exist within a society requiring students to attend school through a certain level (completing primary for example). De jure compulsory schooling laws are legislation that require students to complete a certain level of school or continue in school through a certain age.

Binding compulsory schooling laws work differently than minimum age of employment laws. Minimum age of employment regulation restricts one type of job, inducing substitution to other types of work. Binding compulsory schooling laws put a lower bound on time in education and hence induce a decline in time to be allocated among other activities.

To model this binding constraint, we fix $e$ at some level $k$. The assumption that $\mathrm{k}$ is binding implies that education increases. Absent binding constraints on employment outside the home, this binding compulsory schooling law reduces endowment income by $(p+a w) * k$. The coerced additional expenditure on schooling is $(p+a w) *\left(k-e^{*}\right)$ where $\mathrm{e}^{*}$ is the solution to the unconstrained problem from section A. The reduction in endowment income should reduce leisure and induce a substitution towards more work. It is possible that the decline in endowment time is sufficiently large such that there is less time available to work: $L_{M}^{C^{*}}+L_{H}^{C^{*}}>E^{C}-k$ where $L_{t}^{C^{*}}$ is the optimal time devoted to labor type $t \in\{M, H\}$ in the unconstrained problem of Section A. In this case, work also declines with compulsory schooling. Because of the substitutability of different types of labor (child, adult, outside), there is no clear prediction about the incidence of this decline in work across different locations. 
In sum, binding constraints on the minimum age of employment decrease paid employment outside the home. They have no effect on schooling or labor force participation rates except under saturation. Binding compulsory schooling laws increase education yet have an ambiguous effect on work. They reduce income that can be consumed as living standards by forcing school expenditures and decreasing the time available for work. The reduced income increases demand for children to work, but they may bind such that the desired amount of work absent the constraint is not feasible under the compulsory schooling law.

\section{Empirical Approach}

\section{A. Design}

We assume that absent regulation, age trends in time allocation tend to be smooth. ${ }^{7}$ Minimum age regulations relax at certain ages. Hence, a natural empirical design is to test for breaks in age trends in time allocation at the ages where such regulations are relaxed. Perfectly enforced laws imply no paid employment outside of the home until laws are relaxed and some age trend in participation after employment is permitted. Perfect enforcement does not appear to exist, and we focus our test on the weaker case of whether there appears to be measurable changes in time allocation when minimum age of employment regulation is relaxed.

Our empirical approach is to fit a polynomial to model the age trends when restrictions are in place. We use that polynomial to predict the level of various time allocation measures if the age trend had continued. We then compare this predicted level of the dependent variable under the constrained age trend to the actual level observed in the first year that the restriction is eased. This approach is different than a more standard two-sided design, because we do not observe time allocation above age 14 for most countries in the MICS data. Appendix 2 compares our one-sided results to a more standard two-sided design for countries where this is feasible.

Specifically, let $y_{i c}$ represent the outcome of interest for child $i$ in country $c$. Define the cut age as the age where a minimum age of employment law relaxes. Below the cut age, the parametric assumption on the relationship between $y_{i c}$ and age $A_{i}$ under the constraint is simply:

$$
y_{i c}=\beta_{0}^{c}+\pi_{c}\left(A_{i}\right)+\varepsilon_{i c}
$$

\footnotetext{
${ }^{7}$ This assumption may be inaccurate owing to school transition points or compulsory schooling laws, a subject we will return to later.
} 
where $\pi_{c}\left(A_{i}\right)$ is a polynomial in age. Age is transformed as a deviation from the cut age so that the interpretation of the constant is the estimate of the value of outcome $y$ at the cut age absent the easing of the restriction on minimum age of employment. (10) is only estimated on the sample below the cut age, and the estimate of $\beta_{0}^{c}$ is compared with the sample estimate of $y$ at the cut age, $\bar{y}_{a=c u t}$. That is, the change in outcome $y$ associated with the easing of restrictions on employment is:

(11) $\bar{y}_{a=c u t}^{c}-\beta_{0}^{c} \equiv D_{c u t}^{c}$.

Estimates of $D_{c u t}^{c}$ and its standard error can be obtained collapsing the data to countryage cells and regressing outcome $y$ on a polynomial in age (transformed so that age 0 is the cut age) and an indicator for the cut age using weighted least squares where the weight is the country population in that age cell. $D_{c u t}^{c}$ is the coefficient on the cut age indicator. A similar empirical approach (albeit two-sided) is used by Oreopoulos (2006).

There is, of course, the issue of what order polynomial to fit to the pre-cut age trends in (10). Black et al (2007) emphasize that parametric RD approaches such as the one employed here are sensitive to the choice of specification. We opt for a data driven approach for the choice of the functional form of the polynomial using the Akaike Information Criterion (AIC) employed in Black et al (2007) and discussed in Lee and Lemiuex (2009). Specifically for each country $c$ and each outcome variable $y$ separately we pick the order of the polynomial to minimize: $A I C_{y}^{c}=$ $N^{c} \ln \left({\sigma^{2}}_{y}^{c}\right)+2(p+1)$. Here, ${\sigma^{2}}_{y}^{c}$ is the mean squared error of the regression of outcome $y$ on a polynomial of order $p$ for country $c$ estimated on the country-level age-cell data from below the cut age. $N^{c}$ is the number of observations in the weighted dataset. Given that we only observe ages in years, and we work on the age-cell level, our approach is intrinsically parametric.

One substantive issue in this approach is that we are estimating the impact of extending regulation by one additional year under the assumption that there is a smooth trend in the age pattern of time allocation before regulation is relaxed. Transition points in schooling naturally complicate this assumption. As a robustness check, we have estimated the impact of relaxing minimum age of employment regulations using only data from after the age primary school is usually completed. This restriction to the data limits the number of countries we can consider, but in those countries, we found in our basic results that age explains little variation in time 
allocation and that there is no statistically significant evidence consistent with binding minimum age of employment (although estimates are extremely imprecise when the data is restricted). The smooth age trends assumption is also complicated by other regulations. For example, if compulsory schooling relaxes before the minimum age and compulsory schooling regulation is binding, then the assumption of smooth age trends in estimating the impact of easing minimum age regulation would be incorrect. Likewise, if minimum age regulations bind and relax before compulsory schooling regulations are relaxed, then the assumption of smooth age trends in estimating the impact of easing compulsory schooling would be incorrect. We discuss the salience of these potential econometric problems caused by off-setting regulations in specific country contexts below.

\section{B. MICS Data}

One important advantage of the MICS data for this type of work is that the time allocation module is nearly uniform across countries and between rounds. Thus, while the laws that we are evaluating differ from country to country, the basic measures of time allocation do not. Of course, even though the original questionnaires were largely identical, local understanding of the questions can differ.

The standard MICS questionnaire used in almost all countries contains 7 questions in the child labor module. The reference period is defined as "the last week" for all questions.

Questions are directed towards the mother or caretaker of all children age 5 through 14 although several countries extend the age range to 17 . We choose not to use the data for children 5-7 in our analysis. Participation in paid employment is rare in children below 8 , and heterogeneity in school starting ages creates conceptual difficulties with the younger children. Pooled together, the data represent 158 million children 8-14.

The questionnaire measures two types of non-household employment. We define paid employment as a positive answer to the question of whether the child did any kind of work for someone who is not a member of the surveyed household for pay. While "work" is not defined, the questionnaire stipulates that pay may be for cash or in kind. Unpaid, non-household employment is defined as working in any kind of work over the past week for someone who is not a member of the household without pay. The questionnaire does not allow the respondent to work in both paid and unpaid non-household employment. It asks for total hours in the last week 
in the two types of non-household employment, and it explicitly instructs respondents to combine hours across all non-household jobs.

The questionnaire collects information about household based activities as well. It includes questions about participation and hours in unpaid household services in the last week. It lists "household chores such as shopping, collecting firewood, cleaning, fetching water, or caring for children" as examples of these unpaid household services. The questionnaire also asks about participation and hours in the last week in "other family work," giving work in "the farm or in a business or selling goods in the street" as examples. We label this category "household based economic activity."

Several aggregates will be considered in this discussion. Unpaid economic activity includes household based economic activity and unpaid, non-household employment. Economic activity combines unpaid economic activity with paid employment. Work combines economic activity with unpaid household services. Household based economic activity and services combines household based economic activity with unpaid household services.

Schooling data is also collected in a consistent manner across countries in each round, but the questionnaire changes slightly but substantively between round 2 and round 3 . Both rounds ask whether the child attends school during a reference year and both collect information on number of days attended in the last week. Unlike the time allocation questions where the last week is poorly defined, the school attendance question asks explicitly references "last (day of the week)." This should be how the enumerators implement "last week" in the child labor module as well, but the questionnaire for schooling is more explicit in this regard. There are two other important differences between rounds. First, the age range for school attendance data changes. Schooling attendance is collected for all children age 5-17 in MICS2 and 5-24 in MICS3. Second, MICS 3 is more specific about the reference school year for the attendance question. Round 2 asks about the current school year. Round 3 explicitly identifies the reference year. This could be substantive during interim periods when it is unclear whether the current year would reference the year about to start or the year recently completed (enumerators should have made this clear). Idle children are children that neither work (in economic activity or unpaid household services) nor attend school. We suspect measurement error is an important component of idle status. 
Table 2 contains time allocation summary statistics for the data used in this study. Column 1 pools all the data available in the MICS data. Column 2 contains summary statistics for the pooled MICS2 data. Column 3 contains summary statistics for the pooled MICS3 data. Column 4 bifurcates the pooled MICS rounds into Sub-Saharan Africa and other geographic regions.

The data represent 156 million children, 72 million of whom are in Sub-Saharan Africa (SSA). Nearly 3 percent of children work in paid employment. Three percent of children work in paid employment. Twenty-six percent are engaged in unpaid economic activity. Twenty-eight percent are economically active. Seventy-five percent are engaged in unpaid household services. Seventy-eight percent are in household based activities (combining unpaid household services with household based unpaid economic activity). Eighty percent are engaged in some kind of work. Eighty-two percent attend school, and 4 percent are idle, neither working nor attending school. All work measures are lower and schooling is higher between MICS2 and MICS3. Working children are more prevalent in the SSA countries with unpaid economic activity standing out as a substantive difference. The prevalence of unpaid economic activity is more than double in SSA compared to non-SSA countries.

Summary statistics for time allocation by country for children 8-14 are in Tables $2 \mathrm{~A}$ and 2B. Table 2A contains the SSA countries and Table 2B is the non-SSA countries. In Africa, the measured prevalence of paid employment varies from 0.5 percent of children 8-14 in Djibouti to 16.6 percent in Togo in 2000. The next highest prevalence of paid employment in our African data is from Cameroon in 2000 and Togo in 2006 with 6.7 percent of children 8-14 in paid employment. No attempt was made to have the recall periods for paid employment to be comparable across MICS rounds, so the Togo number differences could owe to the timing of the surveys. Outside of Africa, the greatest prevalence of paid employment in the data is in the Dominican Republic in 2000 where 5 percent of children 8-14 are in paid employment. Figure 1 pools the data from each country (combining MICS data when applicable) and plots participation rates by country.

Participation in economic activity and unpaid household services is more widespread than just paid employment. In Africa, 5 countries have economic activity rates above 70 percent for children 8-14, all observed in 2000: Central African Republic, Chad, Niger, Sierra Leone, and Togo. Outside of Africa, Laos and Albania in 2000 have the highest prevalence of paid 
employment at approximately 40 percent. Participation rates in unpaid household services are above 90 percent in many African countries, with a median participation rate of 86 percent. For non-African countries, participation in unpaid household services is less pervasive. The median participation rate is 73 percent.

School attendance rates and idle status vary substantially across countries. In the African countries, attendance ranges from a low of 43 percent in Niger to a high of 93 percent in Equatorial Guinea. In the non-African countries, many countries report school attendance rates above 98 percent. The median prevalence of idle children in the African countries is 3 percent and 1 percent in non-African countries. Idle status is most frequently observed in Gambia (13 percent), Albania (12 percent), Djibouti (11 percent), and Comoros (10 percent).

Most countries only collect data on economic activities through age 14 and schooling through 17. The last two columns of Tables $2 \mathrm{~A} \& 2 \mathrm{~B}$ indicate the highest age for time allocation and schooling questions respectively although the prevalence rates in Table 2 are restricted to ages 8-14 regardless of whether data is available for older ages. When data on economic activities are only available through 14 , we are only able to use the one-sided design to estimate the impact of relaxing the restriction minimum age of employment (equation 11). Appendix 2 contrasts the one-sided design with a two-sided design in the countries where it is feasible to implement a two-sided empirical design: Gambia, Equatorial Guinea, Kenya, Lesotho, Mongolia, Nigeria, Philippines, Sudan, Swaziland, Togo, Trinidad \& Tobago, Venezuela, and DR Congo.

\section{Main Findings}

\section{A. Analysis of Variance}

Enforced minimum age and compulsory school laws change the age distribution of activities. We begin with the question: how important is age in time allocation? Time allocation varies with age for reasons other than regulation. Physical, mental, and emotional capacities for different types of work vary with human development. While there is ample scope for age to be an important determinant of time allocation even when minimum age regulations are completely unenforced, age appears to have a minor, often negligible, influence on time allocation. On average, age can account for 0.7 percent of the variation paid employment. The lack of explanatory power for age contrasts sharply with other influences that vary at the household, not child level. In African 
MICS countries, age accounts for 0.5 percent of the variation in participation in paid employment (1.1 percent in non-African MICS countries). In contrast, household-level characteristics can account for 67 percent of the variation in participation in paid employment in the African-MICS countries (58 percent in non-African).

To examine the importance of age-specific attributes, we begin by examining how much of the variation in participation in paid employment can be attributed to age. Figure 2 is a histogram of the fraction of the variation in paid employment that can be explained by age for each of the countries in our data. This is the $\mathrm{R} 2$ of a regression of paid employment on a vector of age dummies without controlling for household attributes run separately for each country. The average R2 in the data in Figure 2 is 0.7 percent.

The low explanatory power of age contrasts with the ability of household characteristics to account for variation in paid employment. To compare the explanatory power of age with other child and household attributes, we regress outcomes (we choose paid employment, school attendance, and idle) on dummy variables for age, gender, and household. We then compute what fraction of the total variation in the outcome can be explained by each component of the model as well as the model as a whole. This decomposition exercise is obviously only identified for households with more than 1 child present of school age. We limit our sample accordingly.

Table 3 is this analysis of variance for the pooled data. All individuals are weighted by their inverse sampling probability. The analysis of variance in the pooled data is thus representative of 158 million children 8-14. Each cell contains the fraction of the total sum of squares that can be attributed to the row variable for all countries pooled (column 1), all African MICS countries (column 2), and all Non-African MICS countries (column 3). The first four rows present our findings for paid employment, the next four contain school attendance, and the bottom four examine idle status. Age can explain 0.71 percent of the variation in paid employment in all countries combined, 0.48 percent in Africa, and 1.09 percent in other countries. Household characteristics account for 63.29 percent of the variation in paid employment in all countries, 67.77 percent in Africa. 
Table $3 \mathrm{~A}$ contains the analysis of variance results for Africa. ${ }^{8}$ Table $3 \mathrm{~B}$ is non-Africa. A country is on the row, and the columns correspond to the rows from Table 3 . The first four columns look at paid employment as the outcome. The "model" column reports the fraction of the total sum of squares the model can explain (the R2). Each column is the fraction of the total sum of squares explained by the column variables in the model. This is computed by calculating how the explained sum of squares changes when the column's vector of controls is omitted. 0.48 means that age dummies can explain 48 hundredths of 1 percent of the variation in paid employment in Africa when we condition on gender and household fixed effects.

Figure 3 presents the partial R2s for age and household (child invariant) characteristics from Model 1 in Tables 3A and 3B. Figure 3A is a histogram of the partial R2s for age. It is a histogram of the results from the "Age" column of the "paid employment model" of Tables $3 \mathrm{~A}$ and B. The partial R2s are close to the unconditional R2 in Figure 2 although they are often smaller in magnitude. Age differences are most substantive in Syria, Vietnam, and Bangladesh. Age can never explain more than 2.16 percent of the variation in participation in paid employment. In Africa, Madagascar has the most substantive age differences. In general, age has more explanatory power outside of Africa although there is considerable overlap in the distributions.

Age explains more of the variation in paid employment than schooling. ${ }^{9}$ The African countries drive this observation, because age explains more than double the variation in schooling compared to paid employment in the non-African MICS countries. In fact, within Africa, Nigeria with 19.6 million children aged 8-14 and 68 percent school enrollment is especially important to this result as age explains less than four hundredths of a percent of the variation in schooling for these age ranges. Age accounts for more than 7 times the variation in paid employment in Nigeria compared to schooling. Excluding Nigeria from the analysis, we would find that age explains more of the variation in schooling than paid employment in Africa, like the non-African countries.

\footnotetext{
${ }^{8}$ We believe the unique household identifiers in the Comoros and Cote d'Ivoire data from MICS2 are incorrect, because they are associated with implausible household sizes. We choose to leave them into the table, because we will use their data in our later analysis (which does not depend on having the correct household identifier).

${ }^{9}$ Schooling data is generally available through age 17 . We limit the data to age 14 to match the age range of the paid employment data. The explanatory power of age for the variation in schooling increases dramatically at older ages.
} 
As with paid employment and schooling, age explains little of the variation in idle status. Overall, age can account for half a percent of the variation in idle status. Idle status is more prevalent in African than non-African countries, and age can account for a greater share of the variation in idle status in African MICS countries compared to the non-African countries. DR Congo especially stands out with age accounting for 9 percent of the variation in idle status for its 7.6 million children 8-14.

We focus on age, because binding minimum age of employment regulation impacts the distribution of activities across ages. It is useful to compare the explanatory power of age to gender and household attributes. In African countries, gender accounts for less than a tenth of a percent of the variation in paid employment. Lesotho stands out with gender accounting for 0.68 percent of the variation in paid employment. Gender appears more important outside of Africa and for schooling compared to paid employment. Overall, gender accounts for little of the variation paid employment.

Figure $3 \mathrm{~B}$ is constructed identically to Figure $3 \mathrm{~A}$ except the figure is a plot of the partial R2 for the household fixed effects. The contrast between Figure 3A (partial R2 for age) and Figure 3B (partial R2 for household fixed effects) is striking. Household attributes can account for 63 percent of the variation in the prevalence of paid employment, 70 percent of the variation in school enrollment, and 62 percent of the variation idle status. We do not specify household attributes. The importance of child-invariant household attributes may be driven by low family income, parental characteristics and attitudes, or community level attributes such as the prevalence of certain types of employment or schools. Outside of Comoros and Cote d'Ivoire where we believe the household identifiers are incorrect (the far left tail of figure 3B), household attributes account for a majority of the variation in paid employment in 50 of the 57 countries.

\section{B. The Impact of Light Work Restrictions}

The fact that the variation in paid employment with age is small does not have any implication for whether minimum age regulations influence time allocation. For example, suppose paid employment was flat with respect to age, but the relaxation of constraints lead to a small, onetime jump in the prevalence of paid employment. Age would still explain little of the total variation in paid employment even though there was an effect of regulation.

In this section, we report estimates of (11) for each activity category at the age at which light work is permitted (or light work regulation is no longer binding). The next section contains 
estimates for minimum age of employment regulation, and the final section focuses on compulsory schooling regulation. Obviously, our findings in each section are limited to countries that relax regulation within the age ranges covered in the data. This constraint means that different countries will be included in the results for each section of the paper. Unlike the previous section, where we only used data for children age 8-14, in this section, we use data between ages 8 and the cutoff for the regulation in estimating (11) when the older data is present and relevant.

Table 4 contains results aggregating all countries together and separating out the African countries. For paid employment, the "base" amount is the projected prevalence of paid employment if the time trend in paid employment under regulated ages was extended to the year where the regulation is not longer in place. The "change" is the difference between the actual incidence of paid employment at the age the law relaxes compared to the base level. Thus the "base" level of paid employment is the counterfactual of what paid employment would be at the age where regulation is relaxed absent the relaxation of the regulation on the minimum age of employment. Dividing the change by the base gives the percentage change in paid employment associated with the relaxation of the regulation. All other columns of the table report the "change" column for the dependent variable listed as the column header. We omit the base level for economy for all other outcomes.

We focus on the light work results in this section. When light work is allowed, minimum age regulations are still binding. However, light work regulation would prevent any child employment. Hence, the age at which light work is permitted is the youngest age for which we might see paid employment if the regulations were binding and enforced. We expect the easing of the prohibition on light work to have the same comparative statics as discussed for the relaxation of minimum age of employment regulation earlier in the paper. We should see an increase in paid employment and a decline in household based activity without changes in school attendance.

Our findings for the pooled data are in Table 4. There is no evidence of a change in participation in paid employment with the easing of light work regulation in the pooled data or in the African countries. While the changes in paid employment are especially small, we do not observe t-statistics greater in magnitude than 1 for any of the time allocation measures in Table 4 
in Africa. In the combined data, the only t-statistic greater than 1 is in magnitude is for school attendance, but the estimated percentage change is still less than 10 percent and not significant.

The lack of an impact of easing light work regulation in the aggregate data is clear in

Figure 4. For Figure 4, we have transformed every child's age to a measure that is years since the relaxation of light work regulation in the country (for countries with light work regulation only). Hence -1 implies 1 year before the youngest age that light work regulation is no longer binding, and 0 is the first age a child may work in light work. It is clear that the incidence of paid employment when light work is allowed does not deviate from the trend when restrictions are in place.

Table 5 contains results by outcome and country. The outcome is given by the column heading and each row contains results from different countries. With so many regressions, we will observe many statistically significant changes, so it is important that we focus our discussion on both the significance of changes and whether the patterns in those changes accord to what theory predicts. To see this clearly, we have plotted changes in paid employment and household based work together in Figure 5. Figure 5 contains coefficients and confidence intervals for the change in paid employment at the age of light work from the "change" column of Table 5. In general, countries are identified by their country code (see Table 1), but when multiple MICS are available for the country we have added a 2 or 3 to the country code to make it clear whether the results come from MICS2 or MICS3 for the country. In addition to the change in paid employment confidence intervals and point estimate (diamond), Figure 5 contains the estimated change in household based activity and marks that with a circle. A solid circle indicates that we reject the null of no change in household based activity with 95 percent confidence. A hollow circle indicates 0 is within the 95 percent confidence interval for the parameter.

We observe increases in paid employment with the easing of light work restrictions in 8 countries. We can reject the null that these changes are 0 at a p-value of 0.10 in Mauritania and 0.05 in Trinidad and Tobago. In Mauritania, we observe an increase in household based activities with at the age of easement of regulation that is similar in magnitude to the increase in paid employment we find. Hence, we do not find evidence consistent with binding light work regulation in Mauritania.

Interestingly and nicely illustrating the importance of examining whether we observe changes that match the prediction of theory, in one round of MICS for Trinidad and Tobago, we 
observe a decline in paid employment with the easing of regulation. We observe an increase in the other. Focusing on the 2006 data where we observe the increase in paid employment, we also observe a decline in household based activities and no change in schooling. Hence, the pattern observed in 2006 in Trinidad and Tobago is consistent with binding light work regulation. Between 2000 and 2006, Trinidad increased its regulation so the light work age in 2006 is the minimum age of employment in 2000. This evidence from Trinidad and Tobago, which may reflect the impact of the easing of light work regulation or lagged minimum age of employment regulation, is the only evidence of enforced employment regulation in this study. It is worth noting that compulsory schooling was lifted before light work was allowed in Trinidad and Tobago, so this is one country where our econometric assumption of smooth age trends before light work is permitted may be problematic. However, there is no evidence in Trinidad and Tobago of binding compulsory schooling regulation in the discussion below.

\section{The Impact of Minimum Age (Non-Hazardous Restrictions)}

Minimum age regulations are more prevalent and more restrictive than light work regulation. Hence, we expect a larger impact of their relaxation if they are binding. One rarely hears accounts of the enforcement of light work regulation, but attention is more often brought to minimum age of employment regulation. In our discussion, we do not discuss the impact of removing the restrictions on hazardous work and worst forms of child labor that persist until older ages, because we do not have data on time allocation at older ages and generally those restrictions are on less prevalent work. The minimum age regulations are the relevant regulation for the most common types of paid employment in which children may work.

In the pooled data, there is little to suggest an impact of the relaxation of minimum age of employment restrictions. These estimates are in Table 4 above. Figure 6 presents the pooled findings for paid employment graphically. The construction of the figures is identical to Figure 4, so that 0 is the minimum age at which work is permitted outside of worst forms of child labor. Paid employment is higher than would be predicted by the trend from the ages when employment was restricted. The magnitudes are such that the easing of minimum age of employment regulation increases paid employment by slightly more than 10 percent, although this change is not statistically significant. In Africa (Table 4), we also observe an increase in work inside the household too. We observe a decrease outside of Africa, but both these changes in household based activity are not statistically significant or large in magnitude. 
By country and activity, findings are in Tables $6 \mathrm{~A}$ for Africa and $6 \mathrm{~B}$ for other parts of the world. Figure 7 mimics the format of Figure 5 and presents the changes in paid employment and household based activity graphically. We observe statistically significant increases in paid employment with the relaxation of minimum age regulation in one African country, Nigeria. The magnitude of the estimated increase in paid employment is large in Nigeria, over 50 percent. Bolivia, Bangladesh, and Trinidad and Tobago are the two other countries in the world where we observe statistically significant increases in paid employment at the minimum age for employment.

With a large number of regressions, we expect to see statistical significance by happenstance. In fact, in Figure 7, we observe more statistically significant decreases in paid employment at minimum age of employment than increases. We cannot rely solely on tests of statistical significance in evaluating whether we are observing effects of easing labor regulation. Hence, we examine the countries where we observe significant increases in paid employment for evidence of shifts in work from inside to outside the household. In Nigeria, there is some decline in participation in household based activity, although the change is roughly a third of the magnitude of the increase in paid employment. We also observe large decreases in schooling in Nigeria at the minimum age of employment. In Table 1, it is noted that schooling is no longer compulsory at the minimum age of employment, and the patterns observed in Table 6A are more consistent with the effects of the relaxation of compulsory schooling laws.

In Bangladesh, the observed pattern of responses even more clearly follows the compulsory schooling law predictions although compulsory schooling laws are believed to relax a year before minimum age regulation. Paid employment increases by 1 percentage point ( 25 percent) at the minimum age of employment; the prevalence of any work increases by 3 percentage points; and school attendance declines by 9 percentage points. We observe this pattern that appears consistent with relaxed schooling laws, although in the next section we find no change in schooling at the ages where compulsory schooling is de jure relaxed. This may be a case where de facto schooling norms and de jure schooling regulations differ.

In Bolivia, we observe changes in time allocation that suggest that the statistically significant finding of an increase in paid employment may be spurious. We observe a statistically insignificant increase in household based activity that is similar in magnitude to the increase in 
paid employment. Hence, we do not observe the pattern of changes in time allocation suggested by the theory.

For Trinidad and Tobago, we observe increases in paid employment and increases in household based activities that, together, are nearly double the statistically significant decrease in schooling we observe. If, in fact, light work regulations bound in Trinidad and Tobago, the assumption of smooth age trends under binding minimum age regulation would not be correct. Overall, these Trinidad and Tobago findings for minimum age regulation are difficult to interpret. Like Bangladesh, they are consistent with relaxing compulsory schooling laws. Like Bangladesh, we find no evidence of binding compulsory schooling laws below, so we could be capturing de facto schooling transition points. We have an additional problem here that our light work findings imply substantive concerns about our econometric approach to estimating the impact of relaxing minimum age regulation.

While these are the statistically significant findings, there are many changes in paid employment that are not statistically significant. We observe the general pattern suggested by binding minimum age regulation: increases in paid employment matched by declines in work in the household. To assess this, we plot the estimated changes in paid employment at the minimum age of employment against the estimated changes in household based activity in Figure 8 . The figure includes the linear regression line (solid, bold) and the 45-degree line (light, dashed). While binding minimum age regulation implies that changes in paid employment and household based activity should be negatively correlated, we observe that the association is positive in the data. In fact the quadrant of increasing paid employment and decreasing household based activity has the fewest observations of any of the combinations.

\section{The Impact of Compulsory Schooling Laws}

For the present study, compulsory schooling regulation may present an econometric problem that prevents us from estimating a counterfactual prevalence of paid employment or a confounder that makes it difficult to use theory to identify type I errors. In this section, we use the same empirical approach as the preceding sections to examine the impact of compulsory schooling laws.

We have schooling data for more countries than employment data. In most countries, schooling data is collected for older populations than employment data. Hence, we have estimates of the impact of compulsory schooling laws for a larger set of countries. For these 
additional countries, we cannot assess whether time allocation in activities other than schooling change. Hence, we are more vulnerable to type I errors.

In the pooled data (Table 4), we observe a decline in schooling when schooling is no longer compulsory. The decline in schooling is not matched by an increase in work, inside or outside of the home. The decline in schooling in the pooled data is concentrated in non-African countries. When we focus on Africa alone, the changes in schooling are neither substantive nor significant.

Tables 7A and B contain the individual country- and activity-level estimates of the impact of relaxing compulsory schooling regulation, estimated using (11). We find statistically significant declines in schooling in Burundi, Equatorial Guinea, Ghana, South Sudan, Albania, Azerbaijan, Georgia, Guyana, Iraq, Kyrgyzstan, Macedonia, Moldova, Mongolia, Montenegro, Tajikistan, and Vietnam. Theory predicts that relaxation of binding compulsory schooling restrictions lead to increases in work. Because of missing employment data, we cannot examine the data for this pattern in Ghana, Azerbaijan, Georgia, Guyana, Macedonia, Moldova, Montenegro, Tajikistan, and Vietnam. Among the other countries where we observe declines in schooling when schooling is no longer compulsory, Burundi and Kyrgyzstan are the two countries there are changes in time allocation consistent with theory. Work increases as schooling declines, although we do not find statistically significant or economically meaningful changes in paid employment in either country when schooling is no longer compulsory. Burundi is potentially the most important of these two for our analysis of the impact of minimum age of employment, because schooling is no longer compulsory at an age below the minimum age of employment, and this may bias our ability to estimate a counterfactual prevalence of child time in various activities.

There are 4 countries where we observed increases in paid employment at the minimum age. We identified these as potential type I errors, because we did not see a corresponding decline in household based activity. In fact, we observed a statistically significant increase in unpaid activities as well. All 4 countries have compulsory schooling regulations that relax at the minimum age of employment. Hence, it is possible that we are capturing the effect of compulsory schooling laws on paid employment. However, we do not observe declines in schooling in any of the four countries. 
Nonetheless, we are hesitant to rule out the hypothesis that regulations are most effective when they are coordinated and that we are capturing some effect of coordinated regulation on time allocation. Even though these changes in time allocation do not conform to our prediction for binding minimum age regulation or compulsory schooling separately, the observed changes in time allocation may follow from the combination (although the lack of a change in schooling is not consistent with binding compulsory schooling regulation).

To explore this further, we consider how the impact of the minimum age of employment differs with whether compulsory schooling laws relax at the same age. Our findings in the pooled data are in Table 8. In the first row, we consider the impact of relaxing the minimum age of employment when compulsory schooling laws are not binding. We find no significant changes in time allocation for that group. In the second row, we find that relaxing the minimum age restriction at the same age as compulsory schooling is associated with an increase in paid employment. There is also a decline is school attendance which is large in magnitude, but imprecisely estimated such that we cannot reject the null of no change in school attendance at the age where both regulations relax.

Taken together, the evidence in this section suggests that the minimum age of employment is most apt to be associated with increases in paid employment when the laws are coordinated with compulsory schooling laws. We cannot separate whether this observation owes to selection in who has coordinated laws or an impact of both laws changing at the same time. Given that we do not generally observe statistically significant declines in school in these countries with coordinated laws, we suspect that selection is more important. Nonetheless, it is important to keep these cases in mind in contrast to all other countries where we do not find evidence of binding minimum age of employment regulation.

\section{Conclusion}

Minimum age of employment regulation is a centerpiece in anti-child labor policy, and considerable political attention has been invested in promoting these laws around the world. Minimum age regulations are designed to deter child involvement in paid employment as well as specific types of jobs, and work to change the distribution of job types by age.

In this study, we examine data from 59 countries included in the 2000 and 2005 UNICEF MICS project. We first consider how much of the variation in child engagement can be explained 
by age: less than one percent across the countries studied here. This observation does not inform us whether minimum age regulations influence time allocation. However, the finding that less than one percent of the variation in paid employment among children can be explained by age implies that age based regulation will have limited importance in explaining time allocation. In contrast, child invariant household characteristics account for 63 percent of the variation in child participation in paid employment.

Not only is little of the variation in paid employment associated with age, but we also do not find evidence consistent with binding minimum age of employment regulation for any country. Binding minimum age of employment regulation shifts child labor from outside to inside the household without changing schooling. We do not see evidence consistent with this labor substitution in any country at the minimum age of employment. In fact, there is generally a positive association between changes in paid employment and work inside the household in the data. There are 4 countries where compulsory schooling laws relax at the same as the minimum age of employment and where we find evidence that could be driven by a combination of the two laws. Some countries allow light work at ages below the minimum age of employment, and in 1 one country (Trinidad and Tobago), we observe changes in time allocation that are consistent with changes in time allocation from light work regulation.

Taken together, the evidence in this paper does not suggest an influence of minimum age of employment regulation on child time allocation that is commensurate with the level of policy attention to promoting the regulation. Hence, political economy concerns about the impact of such regulations on constituencies for child labor reform are probably not of first order importance (Deopke and Zilibotti 2005). This raises the question of whether a case can be made for promoting the regulation nonetheless. First, it is important to recall that our findings are only answering the question of what would happen if minimum age of employment regulation were extended an additional year. Hence, we miss any effects of regulations that are gradual. It could be that these regulations signal to uncertain families that they cannot consider work for the child at younger ages. Relaxing the regulation has no immediate effect, but it sets the reference point for families that would otherwise be much earlier. Our design does not capture gradual effects of the regulation. It is useful to recall how little of the variation in paid employment is associated with age. 
Second, our design does not capture general equilibrium effects of the regulation on the structure of employment or prices, including wages, in the overall economy. For example, if minimum age regulation raised wages (as in the Basu and Van 1998 framework), then it would eliminate motives for work compared to the counterfactual of no regulation at all. The regulation would then reduce the incidence of child labor overall, and we might not observe any discreet change in time allocation at the minimum age because the law reduces the supply of child labor. Our design cannot capture any effect of the law beyond the age where the laws are relaxed. Edmonds has argued elsewhere (Edmonds 2008) that such types of general equilibrium responses to child labor regulation are unlikely, but we cannot rule them out with our design.

Third, it may be the case that these laws provide benefits that have nothing to do with changing the time allocation of children at the minimum age. Perhaps they help establish norms over very long time horizons. Perhaps they provide tools for the legal system to go after gross violators. Perhaps they provide organizing principles for other government anti-child labor laws. It is clear from the evidence herein, that minimum age regulations, as currently implemented, do not generally alter child engagement in paid employment at the minimum age itself compared to a counterfactual where the minimum age was set one year later and that child invariant, household characteristics exert a much larger influence on child time allocation in general and child engagement in paid employment in particular.

\section{References}

Banerjee, A.V. And Duflo, E. (2007). “The Economic Lives of the Poor” The Journal of ECONOMIC PERSPECTIVES. 21(1):141-167

Basu, KaUshiK, AND Pham H. VAN. 1998. "The ECONOMics of Child Labor." American ECONOMIC REVIEW 88 (3): 412-427.

Black, Dan, Jose Galdo, and Jeffrey Smith, 2007, "Evaluating the Bias of the REgRESSION DiscontinUity DESIGN Using EXPERIMENTAL DATA," UNIVERSITY OF MiCHIGAN WORKING PAPER.

Dayioglu, M., 2005, "Patterns of Change In Child Labour and Schooling in Turkey: The Impact of COMPulsory Schooling," OXFord Development Studies 33(2), 195 210.

Deopke, M. and Zilibotti, F., 2005, “The Macroeconomics of Child Labor Regulation,” AMERICAN ECONOMIC REVIEW 95(5), 1492-1524.

Edmonds, E. 2008. Child Labor, In T P Shultz ANd J Strauss, (Eds.) HaNdBooK OF DeVElOPMENT ECONOMICS, VOL. 4, CH. 57, 3608-3709.

Goldin, C., and Katz, L., 2003. "Mass Secondary Schooling and the State: The Role of State Compulsion in the High School Movement,” NBER Working PaPer 10075 
Lee, D. And Lemieux, T., 2009, “Regression Discontinuity Design in Economics,” NBER WORKING PAPER 14723.

Lleras-Muney, A., 2001. "Were Compulsory AtTendanCe AND Child Labor LaWs EFFeCTIVE? AN ANALYSIS FROM 1915 TO 1939,” NBER WORKING PAPER 8563.

MANACORDA, M., 2003. "Child LABOR AND THE LABOR SuPPly OF OTHER HOUSEHOld Members: Evidence from 1920 AmericA,” Center for EConomic Performance, LONDON SCHOOL OF ECONOMICS AND POLITICAL SCIENCE, 1-64.

Moehling, C., 1999. "State Child Labor Laws and the Decline of Child Labor," EXPLORATIONS IN ECONOMIC HISTORY 36, 72-106

Oreopoulos, Phillip, 2006, "Estimating Average and Local Average Treatment EFFECTS OF EdUCATION WhEN COMPUlSORY SCHOOLING LAWS REALly MATTER,” AMERICAN ECONOMIC REVIEW 96(1), 152-175.

\section{Appendix One: Review of African Laws on Minimum Age of Employment and Compulsory Schooling}

This appendix provides detail and rational for the coding of minimum age of employment and compulsory schooling laws for the African countries in MICS2 and MICS3. We describe the laws in place at the time of the survey. For countries that fall into both MICS2 and MICS3, we provide detail on changes in law were appropriate. We focus on the describing the actual laws in place (de jure) rather than the behavioral norms that may be appropriate for the country (de facto laws).

We take advantage of the strong global efforts to promote minimum age of employment laws in assembling this appendix. One way advocates, governments, and international organizations hope to affect changes in laws is to raise awareness about the actual laws in place. This provides a natural source of information for us. We will reference the same sources throughout all country descriptions. Hence, we reference them as follows:

- RTE: Right to Education Project. RTE is an effort by ActionAid International to provide detailed description of education laws and child rights laws for every in the world. http://www.right-to-education.org/node/272.

- DOL: United States Department of Labor: Findings on the Worst Forms of Child Labor (From 2001 or 2007). The Trade and Development Act of 2000 required USDOL to provide an annual report on each country eligible for tariff reductions on the Generalized System of Preferences (GSP) concerning whether they are making progress towards the elimination of the worst forms of child labor. These annual reports contain information on the minimum age of employment regulations as well as schooling detail. We use information from the year of the survey, http://www.dol.gov/ilab/programs/ocft/tda.htm

- DOS: U.S. Department of State Country Report on Human Rights Practices. The Foreign Assistance Act of 1961 requires the U.S Department of State to report to the U.S. Congress about the status of each country's compliance with internationally recognized rights, which State interprets as those governed by the Universal Declaration of Human Rights. We use information from the year of the survey, http://www.state.gov/g/drl/rls/hrrpt/ 
- Infodev: Survey of ICT and Education in Africa: Country Reports. infoDev is a World Bank project that contains detail on education laws and practices by country. Country reports are available at http://www.infodev.org/en/Publication.354.html

- UNESCO: UNESCO: Beyond 20/20 WDS. This UNESCO database contains information on education by country and is the source of all of the ages at which primary school is completed. http://stats.uis.unesco.org/unesco/ReportFolders/ReportFolders.aspx

Our primary purpose here is to describe the laws in place at the time of the survey. One concern about measuring the impact of minimum age of employment laws is that there may be other changes, such as the end of primary school, that complicate our econometric approach. Within each country there is variation in when kids start primary school and how long they take to complete. We report the "scheduled progression" age in which children complete primary. Scheduled progression is computed by taking the legislated school starting age and adding the number of grades in primary to that. UNESCO reports the age the student finishes primary if they were to follow this scheduled progression, which of course many do not.

\section{AFRICA}

Angola: The minimum age of employment is set at 14 (RTE, DOL). However, children ages 14-16 require written authorization from a father, guardian, or legal representative (RTE). Children under 16 are not allowed to work in factories, and children under 18 are not allowed to work at night or in "dangerous conditions" (DOL). Schooling is compulsory for 8 years starting at age 6, implying that schooling is compulsory through age 13 (DOL). Primary school is 4 years, implying that children with uninterrupted progression will end primary school at age 9 and will have completed primary school at age 10 (UNESCO). Angola signed C138 and C182 in 2001.

Burkina Faso: The Labor Code sets 15 as the minimum age of employment (DOL). Children under age 18 are restricted from certain businesses and may not work at night. People under age 20 may not perform work that could harm their reproductive abilities. Schooling is compulsory through age 15 (RTE, UNESCO). At the time of the survey, primary school was 6 years starting at age 6 , implying that children with uninterrupted progression would end primary school at age 11 and would have completed primary school at age 12 (UNESCO). Burkina Faso signed C138 in 1999 and C182 in 2001.

Burundi: The Labor Code of 1993 sets 16 as the minimum age of employment (RTE, DOL). Starting at age 12, children may engage in "light work" or apprenticeships so long as they do not jeopardize the child's health, development, or schooling. Children 12-15 may work at most 6 hours per day and may not work at night (DOL). Schooling is compulsory for 6 years starting at age 7 , or through primary school, implying that schooling is compulsory through age 12 (RTE, UNESCO). Burundi signed C138 in 2000 and C182 in 2002. Laws did not change between MICS2 and MICS3.

Cameroon: The Labor Code and the Ministerial Order on Labor sets 14 as the minimum age of employment (DOL). Until age 18, there are restrictions on the type of labor permitted: children may not lift heavy weights, work in "dangerous or unhealthy tasks," or work in tasks that could harm their "morality." Work is also limited to 8 hours per day and must occur during the day (DOS). The Constitution stipulates that education is compulsory through age 14 (DOL, DOS). Primary school is 6 years in Cameroon, implying that children with uninterrupted progression will end primary school at age 11 and will have completed primary school at age 12 
(UNESCO). Cameroon signed C138 in 2001 and C182 in 2002. Relevant laws did not change between MICS2 and MICS3.

Central African Republic: Article 125 of the Labor Code sets 14 as the minimum age of employment (RTE, DOL). However, children may perform light work in traditional agricultural activities or domestic work at age 12 (DOL). Children under 18 may not perform "hazardous work" or work at night (RTE, DOL). Education is compulsory through age 15 (UNESCO). Primary school is 6 years starting at age 6 , implying that children with uninterrupted progression will end primary school at age 11 and will have completed primary school at age 12 . CAR signed C138 and C182 in 2000. Relevant laws did not change between MICS2 and MICS3.

Chad: The Labor Code sets 14 as the minimum age of employment (RTE, DOL). However, children may perform "light and non-hazardous work" at age 12. Jobs deemed hazardous by the government are prohibited until age 18. Schooling is compulsory for 6 years starting at age 6, or through primary school, implying that schooling is compulsory through age 11 (UNESCO). Chad signed C138 in 2005 and C182 in 2000.

Comoros: The Labor Code sets 15 as the minimum age of employment (RTE, DOL). Under the law, children are prohibited from "hazardous activities" (RTE). Schooling is compulsory through age 13 (UNESCO). Primary school is 6 years starting at age 6 , implying that children with uninterrupted progression will end primary school at age 11 and will have completed primary school at age 12. Comoros signed C138 and C182 in 2004.

Cote d'Ivoire: The Labor Code of 1995 sets 14 as the minimum age of employment and the minimum age of apprenticeship (RTE, DOL). Children under age 18 may not work at night or more than 12 consecutive hours, and children under 16 require parent or legal guardian permission (DOL). There is no compulsory schooling in Cote d'Ivoire (RTE, DOS). Primary school is 6 years starting at age 6 , implying that children with uninterrupted progression will end primary school at age 11 and will have completed primary school at age 12 (UNESCO). Cote d'Ivoire signed C138 and C182 in 2003. Relevant laws did not change between MICS2 and MICS3.

Democratic Republic of Congo: At the time of the survey, the Labor Law set 14 as the minimum age of employment (RTE, DOL). However, children ages 14-15 were only allowed to perform "light, healthy work" (DOL). Children under 18 required the consent of a parent or guardian and were not allowed to work at night, children under 16 were allowed to work at most 4 hours per day, and children 16-17 were allowed to work at most 8 hours per day (RTE). Schooling is compulsory for 8 years starting at age 6 , implying that schooling is compulsory through age 13 (UNESCO). Sources contradict, but this seems to be the modal age reported. Primary school is 6 years starting at age 6 , implying that children with uninterrupted progression will end primary school at age 11 and will have completed primary school at age 12 (UNESCO). DR Congo signed C138 and C182 in 2001.

Equatorial Guinea: The minimum age of employment is set at 14 (RTE). We found other characterizations of the relevant labor law, but this codification seemed to have the most support. At age 13, children may work in "light" jobs that do not affect their "health, growth, or school attendance;" and at age 12, children may work in agriculture or craft making. Children under 16 are restricted from work that might harm their "health, safety or morals." Schooling is compulsory through primary school, which is 5 years starting at age 7, implying that children with uninterrupted progression will end primary school at age 11 and will have completed primary school at age 12 (UNESCO). Equatorial Guinea signed C138 in 1985 and C182 in 2001. 
Gambia: The labor code in effect for 2001 set 18 as the minimum age of employment (DOL). In 2005, the Children's Act reduced the minimum age of employment to 16 years (DOL). However, children ages 16-17 are only permitted to perform "light work" and are prohibited from working at night or in "hazardous" jobs. Apprenticeships are allowed at age 12. Primary school is compulsory for 5 years starting at age 7 (UNESCO). Several sources report that primary school is compulsory through age 8 , but 12 seems to be the modal age reported and is consistent with the legal school entry age of 7 (e.g. UNESCO). ${ }^{10}$ Gambia signed C138 in 2000 and $\mathrm{C} 182$ in 2001.

Ghana: Ghanaian law sets 15 as the minimum age for employment and 13 as the minimum age for light work (RTE, DOL). Light work is defined as that which is not harmful to health, development, or schooling. Children under 18 may not work at night or in "hazardous" activities (DOL). Under a 1987 law, schooling is compulsory for 9 years starting at age 6, implying that schooling is compulsory through age 14 (RTE). Primary school is 6 years, implying that children with uninterrupted progression will end primary school at age 11 and will have completed primary school at age 12 (UNESCO). Ghana has not signed C138 and signed C182 in 2000.

Guinea Bissau: The General Labor Law of 1986 sets 14 as the minimum age of employment for factor work and 18 as the minimum age for "heavy or dangerous labor" (DOL). Schooling is compulsory through age 12 (RTE, Infodev, UNESCO). Primary school is 6 years starting at age 7, implying that children with uninterrupted progression will end primary school at age 12 and will have completed primary school at age 13 (UNESCO). Guinea Bissau signed C138 in 2009 and C182 in 2008. Relevant laws did not change between MICS2 and MICS3.

Kenya: The minimum age of employment is set at 16 (RTE). However, children as young as 13 may engage in light work (undefined). The Employment Act of 1976 prohibits children under 16 from industrial undertakings (RTE, DOL). Schooling is compulsory for 8 years starting at age 6, implying that schooling is compulsory through age 13 (RTE, UNESCO). Primary school is 6 years, implying that children with uninterrupted progression will end primary school at age 11 and will have completed primary school at age 12 (UNESCO). Kenya signed C138 in 1979 and C182 in 2001.

Lesotho: The Labor Code of 1992 sets 15 the minimum age of employment for industrial work or private undertakings involving family (DOL). However, at age 13, children may work in "light work" if it is done in a technical school approved by the Department of Education. Children under 16 may work at most 8 hours per day and may not work at night. Children under 18 may not perform "hazardous" work. Schooling is not compulsory in Lesotho (RTE, DOS, UNESCO). Primary school is 7 years starting at age 6, implying that children with uninterrupted progression will end primary school at age 12 and will have completed primary school at age 13 (UNESCO). Lesotho signed C182 and C138 in 2001.

Madagascar: The Labor Code sets 15 as the minimum age of employment (DOL, DOS). Children under 18 may not perform night work or work that could endanger their "health, safety, or morals." Schooling is compulsory through age 14 (DOL, UNESCO). Primary school is 5 years starting at age 6 , implying that children with uninterrupted progression will end primary school at age 10 and will have completed primary school at age 11 (UNESCO). Madagascar signed C138 in 2000 and C182 in 2001.

\footnotetext{
${ }^{10}$ A number of reports (DOS, DOL) list age 8 at the end of compulsory school. This used to be the start of compulsory schooling in the 1980s. Hence, we are confident that this is inaccurate.
} 
Malawi: The Employment Act of 2000 sets 14 as the minimum age of employment (RTE, DOL). Exceptions are made for certain types of work in training institutions or homes (DOL). Children under 18 may not be employed in work that could harm their "health, safety, development, education, or morals." Education is not compulsory in Malawi (RTE, DOL). Primary school is 6 years starting at age 6, implying that children with uninterrupted progression will end primary school at age 11 and will have completed primary school at age 12 (UNESCO). Malawi signed C182 and C138 in 1999.

Mauritania: The Labor Code of 2004 sets 14 as the minimum age of employment unless the child has not completed the 9 years of compulsory education (DOL). At age 12, family-based light work is permitted provided it is approved by the Minister of Labor, is not more than 2 hours per day, and is not on Fridays. Children under 16 are prohibited from night work and children under 18 are prohibited from work that "is likely to harm their safety, health, or morals." At the time of the survey, schooling was compulsory for 9 years starting at age 6, implying that schooling was compulsory through age 14 (RTE, DOL, UNESCO). Primary school is 6 years, implying that children with uninterrupted progression will end primary school at age 11 and will have completed primary school at age 12 (UNESCO). Mauritania signed C138 and C182 in 2001.

Niger: The 1996 Labor Code sets 14 as the minimum age of employment (RTE, DOL). However, children under 14 may work with special authorization (DOL). Children under 18 may not work more than 4.5 hours per day, at night, or in industrial jobs. Schooling is compulsory for 6 years starting at age 7 , or through primary school, implying that schooling is compulsory through age 12 (DOS, DOL, UNESCO). Niger signed C138 in 1978 and C182 in 2000.

Nigeria: The Nigerian Labor Act of 1990 sets 15 as the minimum age of employment (DOL). It excludes family-based light work (RTE, DOL). Children under 16 may not work at night, more than 8 hours per day, or in "dangerous or immoral" employment. Schooling is compulsory for 9 years starting at age 6, implying that schooling is compulsory through age 14 (Infodev, UNESCO). Primary school is 6 years, implying that children with uninterrupted progression will end primary school at age 11 and will have completed primary school at age 12 (UNESCO). Nigeria signed C138 and C182 in 2002.

Rwanda: At the time of the survey, the Labor Code prohibited the employment of anyone under age 18 without parental permission (RTE, DOS). Apprenticeships were allowed at age 14 provided the child had completed primary school (DOS). Children under 18 were prohibited from working at night. The temporary employment of children under 14 could be authorized in exceptional circumstances (RTE). We code 18 as the minimum age of employment, although it is not clear that this is consistent with how we have interpreted other laws. Schooling is compulsory through primary school, which is 6 years starting at age 7, implying that schooling is compulsory through age 12 (RTE, DOL, UNESCO). Rwanda signed C138 in 1981 and C182 in 2000.

Sao Tome: The minimum age of employment is set at 14 (RTE, DOS). However, children under 18 may work at most 7 hours per day and 45 hours per week and may not perform "dangerous" jobs or heavy manual labor (DOS). At the time of the survey, schooling was compulsory through primary school, which was 6 years starting at age 7, implying that schooling was compulsory through age 12 (RTE, UNESCO). C138 and C182 were both signed in 2005.

Senegal: The minimum age of employment for all forms of work is 18 expect for apprenticeships, which are allowable at age 16 (DOL, DOS). Secular schooling is compulsory through age 16 after a 2004 law (RTE). Primary school is 6 years starting at age 7, implying that 
children with uninterrupted progression will end primary school at age 12 and will have completed primary school at age 13 (UNESCO). Senegal signed C138 in 1999 and C182 in 2000.

Sierra Leone: The Employers and Employed Act of 1960 is the main regulation governing child labor at the time of writing and for the period of both MICS surveys (RTE). At age 12, children may enter into "light" labor in a family endeavor (DOS). At age 15, they may work away from home so long as it is during the day, above ground, and in a "non-hazardous" occupation (RTE, DOL). Schooling is compulsory through primary school, which is 6 years starting at age 6, implying that schooling is compulsory through age 11 (DOS, UNESCO). Sierra Leone has not signed $\mathrm{C} 138$ or $\mathrm{C} 182$ at the time of writing. Relevant laws did not change between MICS2 and MICS3.

Somalia: Somalia has been without a functioning government since 1991 (DOL). In 1998, schooling was compulsory through age 13 (DOL, UNESCO). Primary school is 6 years starting at age 6 , implying that children with uninterrupted progression will end primary school at age 11 and will have completed primary school at age 12 (UNESCO). Somalia has not signed C138 or C182.

Sudan (North and South): The Labor Act of 1997 defines a young person as a person under age 16 (RTE). Young people are not permitted to work in jobs that are hazardous or harmful, at night, or for more than 7 consecutive hours. Children under 18 are not allowed to work outside of apprenticeships, training sessions, and family enterprises. We were unable to identify any age restrictions regarding light work that conforms to the restrictions above. Effective in 2000, schooling is compulsory for 8 years beginning at age 6 , implying that schooling is compulsory though age 13 (RTE, DOS, UNESCO). Primary school is 6 years starting at age 6, implying that children with uninterrupted progression will end primary school at age 11 and will have completed primary school at age 12 (UNESCO). Sudan signed C138 in 2002 and $\mathrm{C} 182$ in 2003.

Swaziland: The Employment Act of 1980 sets 15 as the minimum age of employment in non-hazardous industrial work (DOL). Children under 15 may be hired in enterprises that employ only family members and may not work at night or for more than 6 hours per day. Children under 18 may not perform "underground, dangerous or unhealthy work" (RTE). Schooling is not compulsory in Swaziland (RTE, DOL, UNESCO). Primary school is 7 years starting at age 6, implying that children with uninterrupted progression will end primary school at age 12 and will have completed primary school at age 13 (UNESCO). Swaziland signed C138 and $\mathrm{C} 182$ in 2002.

Togo: At the time of MICS2, the minimum age of employment was regulated by a 1958 law that set 14 as the minimum age of employment (RTE, DOL). Even apprenticeships were prohibited below age 14, and certain industrial and technical jobs were restricted until age 18 (DOL). During the fielding of MICS3, a new labor code raised the minimum employment age in any enterprise to 15 . However, MICS3 fieldwork was largely completed, so we treat the 1958 law as the relevant minimum age of employment regulation (DOL). A 1995 education reform made schooling compulsory through age 15 (DOS, RTE). Primary school is 6 years starting at age 6, implying that children with uninterrupted progression will end primary school at age 11 and will have completed primary school at age 12 (UNESCO). Togo signed C138 in 1984 and C182 in 2000. Laws regarding the minimum age of employment changed between MICS2 and MICS3.

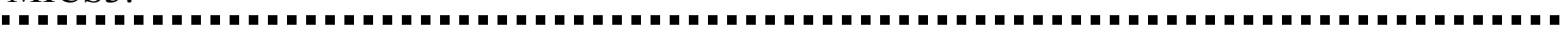


Zambia: The Employment of Young Persons and Children Act sets 14 as the minimum age of employment (RTE, DOL). However, children under 14 are permitted to work in enterprises where only family members are employed (RTE). Schooling is not compulsory in Zambia (RTE, DOL). Primary school is 7 years starting at age 7, implying that children with uninterrupted progression will end primary school at age 13 and will have completed primary school at age 14 (UNESCO). Togo signed C138 in 1976 and C182 in 2001.

\section{EUROPE AND CENTRAL ASIA}

Albania: The Labor Code sets 16 as the minimum age of employment (RTE, DOL). Children ages 14-18 may perform "light work," as defined by the Council of Ministers, during school vacations. Children under 18 may work at most 6 hours per day and may not work at night (DOL). Schooling is compulsory for 8 years starting at age 6, implying that schooling is compulsory through age 13 (RTE, UNESCO). Primary school is 4 years, implying that children with uninterrupted progression will end primary school at age 9 and will have completed primary school at age 10 (UNESCO). Albania signed C138 in 1998 and C182 in 2001. Relevant laws did not change between MICS2 and MICS3.

Azerbaijan: The minimum age of employment is set at 16 (DOS). However, children ages 14-15 may enter employment if they have the consent of their parents. Children ages 14-16 are limited to working at most 24 hours per week. Schooling is compulsory through age 16 (DOS, UNESCO). Primary school is 4 years starting at age 6, implying that children with uninterrupted progression will end primary school at age 9 and will have completed primary school at age 10 (UNESCO). Azerbaijan signed C138 in 1992 and C182 in 2004.

Belarus: The Labor Code sets 16 as the minimum age of employment (RTE, DOS). However, children as young as 14 may enter employment if they have the written consent of a parent or legal guardian. Children under 18 may not work overtime or on weekends and may not perform work that jeopardizes their health or education (DOS). Schooling is compulsory for 9 years starting at age 6, implying that schooling is compulsory through age 14 (DOS, UNESCO). Primary school is 4 years, implying that children with uninterrupted progression will end primary school at age 9 and will have completed primary school at age 10 (UNESCO). Belarus signed C138 in 1979 and C182 in 2000.

Bosnia and Herzegovina: The Labor Law sets 15 as the minimum age of employment (RTE, DOL). Children under 18 may not work in "hazardous" occupations. Schooling is compulsory through age 14 (DOL, UNESCO). Primary school is 4 years starting at age 6, implying that children with uninterrupted progression will end primary school at age 9 and will have completed primary school at age 10 (UNESCO). Bosnia and Herzegovina signed C138 in 1993 and C182 in 2001. Relevant laws did not change between MICS2 and MICS3.

Georgia: The Labor Code of 2006 sets 16 as the minimum age of employment (RTE, DOL). However, children as young as 14 may enter employment if they have parental consent, so long as the work does not jeopardize the child's health or schooling (DOL). Children ages 1617 may work at most 36 hours per week, children ages 14-15 may work at most 24 hours per week, and children under 18 may not work in "heavy, harmful, or dangerous work" (DOL). Schooling is compulsory for 9 years starting at age 6 , implying that schooling is compulsory through age 14 (UNESCO). Primary school is 4 years, implying that children with uninterrupted progression will end primary school at age 9 and will have completed primary school at age 10 . Georgia signed C138 in 2000 and C182 in 2002. 
Kazakhstan: The Labor Act sets 16 as the minimum age of employment (RTE, DOL). However, children may work with parental consent at age 15 if they have completed their compulsory education. Children at age 14 may perform "light work," so long as the work does not jeopardize health or schooling (DOL). Children ages 14-15 may work at most 24 hours per week, children 16-17 may work at most 36 hours per week, and children under 18 may not work in "dangerous" conditions, overtime, or at night. Schooling is compulsory for 11 years starting at age 7, implying that schooling is compulsory through age 17 (UNESCO). Primary school is 4 years, implying that children with uninterrupted progression will end primary school at age 10 and will have completed primary school at age 11. Kazakhstan signed C138 in 2001 and C182 in 2003.

Kyrgyzstan: The minimum age of employment is set at 16 (RTE, DOL). However, children as young as 14 may enter employment if they have written consent from a parent or legal representative (RTE). "Light work" is also permitted at age 14 (DOL). Children ages 14-15 may work at most 5 hours per day, children ages 16-17 may work at most 7 hours per day, and children under 18 are banned from certain industries such as oil and mining. Schooling is compulsory for 9 years starting at age 7, implying that schooling is compulsory through age 15 (RTE, UNESCO). Primary school is 4 years, implying that children with uninterrupted progression will end primary school at age 10 and will have completed primary school at age 11 (UNESCO). Kyrgyzstan signed C138 in 1992 and C182 in 2004.

Macedonia: The Constitution sets 15 as the minimum age of employment (RTE, DOL). Children under 18 may not work overtime, at night, or in jobs that are "detrimental to their health or morality" (DOL). Children under 15 may work as an apprentice or in official vocational programs. Schooling is compulsory for 8 years beginning at age 7, implying that schooling is compulsory through age 14 (RTE, DOL, UNESCO). Primary school is 4 years, implying that children with uninterrupted progression will end primary school at age 10 and will have completed primary school at age 11 (UNESCO). Macedonia signed C138 in 1991 and C182 in 2002.

Moldova: The Labor Code sets 16 as the minimum age of employment (RTE, DOL). However, the Law on Children's Rights allows children to work in "easy activities" for purposes of training at age 14 with parental consent, if the work does not interfere with school. Children under 18 are not allowed to perform hazardous work, such as work underground (DOL). Schooling is compulsory for 9 years starting at age 7 , implying that schooling is compulsory through age 15 (RTE, DOL, UNESCO). Primary school is 4 years, implying that children with uninterrupted progression will end primary school at age 10 and will have completed primary school at age 11 (UNESCO). Moldova signed C138 in 1999 and C182 in 2000.

Montenegro: The minimum age of employment is 15 (DOS, DOL). Children under 18 are not allowed to work overtime, at night, underground, or in jobs that "may have a harmful effect on or involve increased risk for their health and lives" (DOL). At the time of MICS3, schooling was compulsory for 8 years starting at age 7 , implying that schooling was compulsory through age 14 (DOS, UNESCO). Primary school was 4 years, implying that children with uninterrupted progression would end primary school at age 10 and would have completed primary school at age 11 (UNESCO). Montenegro signed C138 in 2006 and C182 in 2006.

Serbia: The Labor Law sets 15 as the minimum age of employment (RTE, DOL). Children under 18 require written consent from a parent or guardian; may not work overtime, at night, or under conditions that "jeopardize their health, morals and education;" and are limited to a maximum of 35 hours per week (DOL). Schooling is compulsory for 8 years starting at age 7, 
implying that schooling is compulsory through age 14 (RTE, UNESCO). Primary school is 4 years, implying that children with uninterrupted progression will end primary school at age 10 and will have completed primary school at age 11 (UNESCO). Serbia signed C138 in 2000 and C182 in 2003.

Tajikistan: The minimum age of employment is 16 (DOS). However, children as young as 7 may perform "family assistance,"- domestic and agricultural labor. Children under 18 may not work more than 6 hours per day and 36 hours per week. Schooling is compulsory through age 15 (DOS, UNESCO). Primary school is 4 years starting at age 7, implying that children with uninterrupted progression will end primary school at age 10 and will have completed primary school at age 11 (UNESCO). Tajikistan signed C138 in 1993 and C182 in 2005. Relevant laws did not change between MICS2 and MICS3.

Ukraine: The minimum age of employment is set at 16 (RTE, DOL). However, children with parental consent may work at 15 . At age 14, children may perform "light work" for purposes of training if the work does not jeopardize their health or schooling (RTE). At the time of MICS2, schooling was compulsory for 11 years starting at age 7, implying that schooling was compulsory through age 17 (UNESCO). Primary school was 3 years, implying that children with uninterrupted progression would end primary school at age 9 and would have completed primary school at age 10. At the time of MICS3, schooling was compulsory for 12 years starting at age 6 , implying that schooling was still compulsory through age 17. Primary school was 4 years, implying that children with uninterrupted progression would end primary school at age 9 and would still have completed primary school at age 10. Ukraine signed C138 in 1979 and C182 in 2000 .

Uzbekistan: The Labor Code sets 16 as the minimum age of employment (RTE, DOL). However, children at age 14 may perform "light work" in preparation for employment that does not jeopardize their schooling or health (RTE). Children under 18 have limited work hours and may not work in "unfavorable labor conditions" (DOL). At the time of MICS2, schooling was compulsory for 11 years starting at age 7 , implying that schooling was compulsory through age 17 (UNESCO). At the time of MICS3, schooling was compulsory for 12 years starting at age 7, implying that schooling was compulsory through age 18. At the time of both surveys, primary school was 4 years, implying that children with uninterrupted progression would end primary school at age 10 and would have completed primary school at age 11. Uzbekistan signed C138 in 2009 and $\mathrm{C} 182$ in 2008.

\section{EAST ASIA AND PACIFIC}

Indonesia: The minimum age of employment is set at 15 (RTE, DOL). Children under 18 may not perform "hazardous work." Schooling is compulsory for 9 years starting at age 7 , implying that schooling is compulsory through age 15 (RTE, UNESCO). Primary school is 6 years, implying that children with uninterrupted progression will end primary school at age 12 and will have completed primary school at age 13 (UNESCO). Indonesia signed C138 in 1999 and $\mathrm{C} 182$ in 2000.

Laos: The Labor Code sets 15 as the minimum age of employment (RTE, DOL). Children under 18 may not work for more than 6 hours per day or 36 hours per week and may not work in sectors involving "heavy work or health hazards" (RTE). Children under 15 may work for their families. Schooling is compulsory through primary school, which is 5 years starting at age 6, implying that children with uninterrupted progression will end primary school 
at age 10 and will have completed primary school at age 11 (RTE, UNESCO). Burundi signed C138 and C182 in 2005. Relevant laws did not change between MICS2 and MICS3.

Mongolia: The Labor Law sets 16 as the minimum age of employment (DOL). However, children may enter employment at age 14 if they have parental consent. Children ages 14-15 may work at most 30 hours per week, children 16-17 may work at most 36 hours per week, and children under 18 may not work overtime or in certain hazardous activities specified by the government (RTE, DOL). At the time of MICS2, schooling was compulsory for 8 years starting at age 8 , implying that schooling was compulsory through age 15 (DOL, UNESCO). At the time of MICS3, schooling was compulsory for 9 years starting at age 8, implying that schooling was compulsory through age 16 (UNESCO). At the time of both surveys, primary school was 4 years, implying that children with uninterrupted progression would end primary school at age 11 and would have completed primary school at age 12 (UNESCO). Mongolia signed C138 in 2002 and C182 in 2001. Relevant laws did not change between MICS2 and MICS3.

Myanmar: The Factories Act of 1951 sets 13 as the minimum age of employment (RTE). Children under 16 may work at most 4 hours per day and may not work at night or on Sunday. Children under 18 may not perform work that is harmful to their life, health, or "moral character." Schooling is compulsory through primary school, which is 5 years starting at age 5, implying children with uninterrupted progression will end primary school at age 9 and will have completed primary school at age 10 (UNESCO). Myanmar has not signed C138 or C182.

Philippines: The Labor Code of 1993 and Republic Act No. 7658 of 1993 set 15 as the minimum age of employment (RTE, DOL). However, children under 15 may work for their parents if it does not jeopardize their health, schooling, or "morals" (RTE). At age 14, children may enter into apprenticeships (DOL). Children under 18 are prohibited from "hazardous" work. Schooling is compulsory through primary school, which is 6 years starting at age 6 , implying that children with uninterrupted progression will end primary school at age 11 and will have completed primary school at age 12 (RTE, DOL). The Philippines signed C138 in 1998 and C182 in 2000.

Thailand: The Labor Protection Act of 1998 sets 15 as the minimum age of employment (RTE, DOL). However, children under 18 require written permission from the Director-General of Labor, may only work between 4 p.m. and 10 p.m., and may not be employed in hazardous work, such as metalworking (DOL). These provisions do not apply to the agricultural or informal sectors. Schooling is compulsory for 9 years starting at age 6, implying that schooling is compulsory through age 14 (UNESCO). Primary school is 6 years, implying that children with uninterrupted progression will end primary school at age 11 and will have completed primary school at age 12. Thailand signed C138 in 2004 and C182 in 2001.

Vanuatu: Under the Labor Code, children under age 14 may only be employed in light work of agricultural or domestic nature (RTE). At age 15, children may perform industrial work. Children under 18 are subject to restrictions involving working at night or in the shipping industry (DOL). Schooling is not compulsory in Vanuatu (RTE). Primary school is 6 years starting at age 6, implying that children with uninterrupted progression will end primary school at age 11 and will have completed primary school at age 12 (UNESCO). Vanuatu has not signed C138 but signed C182 in 2006.

Vietnam: The Labor Code of 1994 sets 15 as the minimum age of employment (RTE). Children under 18 may work at most 7 hours per day and 42 hours per week and may not undertake hazardous work as specified by the Labor Law (DOL). Schooling is compulsory through the age of 14 (RTE, DOL, UNESCO). Primary school is 5 years starting at age 6, 
implying that children with uninterrupted progression will end primary school at age 10 and will have completed primary school at age 11 (UNESCO). Vietnam signed C138 in 2003 and C182 in 2000. Relevant laws did not change between MICS2 and MICS3.

\section{MIDDLE EAST AND NORTH AFRICA}

Djibouti: Article 5 of the Labor Code of 2000 sets 16 as the minimum age for employment (RTE, DOL). Children ages 16-17 may not work as domestic servants or in hotels or bars (DOL). Schooling is compulsory for 9 years starting at age 6 , implying that schooling is compulsory through age 14 (RTE, UNESCO). Primary school is 6 years, implying that children with uninterrupted progression will end primary school at age 11 and will have completed primary school at age 12 (UNESCO). Djibouti signed C138 and C182 in 2005.

Iraq: The Labor Act of 1987 sets 15 as the minimum age of employment (RTE, DOL). Children under 18 are subject to laws limiting work hours and type of occupation. Schooling is compulsory through primary school, which is 6 years beginning at age 6 , implying that children with uninterrupted progression will end primary school at age 11 and will have completed primary school at age 12 (UNESCO). Iraq signed C138 in 1985 and C182 in 2001. Relevant laws did not change between MICS2 and MICS3.

Syria: The private sector minimum age of employment is set at 15 for most nonagricultural labor (DOS). Children under 18 may not work at night, on weekends, or on "heavy work." Those who are not technically paid a salary do not fall under the law. Schooling is compulsory for 9 years beginning at age 6, implying that schooling is compulsory through age 14 (UNESCO). Primary school is 6 years, implying that children with uninterrupted progression will end primary school at age 11 and will have completed primary school at age 12 . Syria signed C138 in 2001 and C182 in 2003.

Yemen: The minimum age of employment is set at 15 for the private sector and 18 for the public sector (DOL). Children ages 12-14 may work by special permit. Children under 18 may not work in "hazardous or socially damaging working conditions." Schooling is compulsory through age 14 (DOL, UNESCO). Primary school is 6 years starting at age 6 , implying that children with uninterrupted progression will end primary school at age 11 and will have completed primary school at age 12 (UNESCO). Yemen signed C138 and C182 in 2000.

\section{SOUTH ASIA}

Bangladesh: The minimum age of employment varies by sector (RTE, DOL). Children may work in shops and workshops at age 12; factories at age 14; mines, railways, ports, and tea gardens at age 15; and brothels at age 16. The law does not apply to informal sectors such as agriculture and domestic work. Schooling is compulsory through age 10 (RTE, DOL, UNESCO). Primary school is 5 years starting at age 6 , implying that children with uninterrupted progression will end primary school at age 10 and will have completed primary school at age 11 (UNESCO). Bangladesh has not signed C138 and signed C182 in 2001.

\section{LATIN AMERICA AND CARIBBEAN}


Belize: The Labor Act sets 14 as the minimum age of employment (RTE). However, at age 12, children may perform "light work" after school hours (DOL). Schooling is compulsory through age 14 (RTE, DOL). Primary school is 6 years beginning at age 5, implying that children with uninterrupted progression will end primary school at age 10 and will have completed primary school at age 11 (UNESCO). Belize signed C138 and C182 in 2000.

Bolivia: The Child and Adolescent Code sets 14 as the minimum age of employment (RTE, DOL). The General Labor Law specifies that children under 14 may work as apprentices. At the time of MICS2, schooling was compulsory for 8 years starting at age 6 , implying that schooling was compulsory through age 13 (DOL, UNESCO). Primary school is 6 years, implying that children with uninterrupted progression will end primary school at age 11 and will have completed primary school at age 12 (UNESCO). Bolivia signed C138 in 1997 and C182 in 2003.

Cuba: The minimum age of employment is set at 17 (RTE, DOL). However, children ages 15-16 may work to obtain training or fill labor shortages (DOL). At 14, children may enter into apprenticeships (RTE). Teenagers may not work more than 7 hrs per day or 40 hours per week and are forbidden from certain hazardous occupations (DOL). Schooling is compulsory for 9 years starting at age 6, implying that schooling was compulsory through age 14 (UNESCO). Primary school is 6 years, implying that children with uninterrupted progression will end primary school at age 11 and will have completed primary school at age 12. Cuba signed C138 in 1975 and has not signed C182.

Dominican Republic: The Labor Code sets 14 as the minimum age of employment (RTE, DOL). Children under age 16 may not work more than 6 hours per day, may not work at night, and are restricted from certain types of work (DOL). Schooling is compulsory for 8 years starting at age 6, implying that schooling is compulsory through age 13 (RTE). Primary school is 6 years, implying that children with uninterrupted progression will end primary school at age 11 and will have completed primary school at age 12 (UNESCO). The Dominican Republic signed C138 in 1999 and C182 in 2000.

Guyana: The Employment of Young Persons and Children Act of 1999 sets 15 as the minimum age of employment (DOL). Children under age 18 may not perform work that could jeopardize their "health, safety or morals." Schooling is compulsory through age 14 (RTE, UNESCO). Primary school is 6 years starting at age 6, implying that children with uninterrupted progression will end primary school at age 11 and will have completed primary school at age 12 (UNESCO). Guyana signed C138 in 1998 and C182 in 2001. Relevant laws did not change between MICS2 and MICS3.

Jamaica: The Juveniles Act of 1951 sets 12 as the minimum age of employment (RTE, DOL). However, children under 12 may work in family domestic, agricultural, or horticultural work (DOL). Children under 15 may not be employed on a ship or in industrial work (RTE, DOL). Children under 16 may not be employed in night work or "hazardous" work (RTE). Schooling is compulsory through age 11 (DOL, UNESCO). Primary school is 6 years starting at age 6 , implying that children with uninterrupted progression will end primary school at age 11 and will have completed primary school at age 12 (UNESCO). Jamaica signed C138 and C182 in 2003. Relevant laws did not change between MICS2 and MICS3.

Suriname: The Labor Act sets 14 as the minimum age of employment (DOL). At age 12, children may enter into employment if it is "specifically designed for children, does not require much physical or mental exertion, and is not dangerous." We code 12 in the light work category, although it is not clear that this is consistent with how we have interpreted other laws. Schooling 
is compulsory through age 11 (RTE, DOL, UNESCO). Primary school is 6 years beginning at age 6, implying that children with uninterrupted progression will end primary school at age 11 and will have completed primary school at age 12 (UNESCO). Suriname has not signed C138 and signed C182 in 2006. Relevant laws did not change between MICS2 and MICS3.

Trinidad and Tobago: At the time of MICS 2, the minimum age of employment was set at 12 , but children under 14 could not work unless only members of the same family were employed (RTE, DOL). We code 14 as the minimum age of employment and 12 in the light work category, although it is not clear that this is consistent with how we have interpreted other laws. Children under 18 could not work at night, with the exception of children over 16 in sugar factories. In 2006, the minimum age of employment was set at 16 for private and public industries (DOL). However, children ages 14-15 could work if only members of the same family were employed or if the work was approved as vocational or technical training by the Ministry of Education. At the time of the surveys, schooling was compulsory through age 11 (RTE, UNESCO). Primary school was 7 years starting at age 5, implying that children with uninterrupted progression would end primary school at age 11 and would have completed primary school at age 12 (UNESCO). Trinidad and Tobago signed C138 in 2004 and C182 in 2003.

\section{Appendix Two: Comparison of One-Sided and Two-Sided Discontinuity Estimates}

For most countries, child labor related data is only collected in our data up to the minimum age of employment. Hence, in general, we cannot exploit age trends in time allocation after the age minimum age of employment laws are relaxed. Thus, we rely on the one-sided design in equation (10) and (11).

However, there are a few countries where we have information on child labor related time allocation for several years past the minimum age of employment. Those countries are Gambia, Equatorial Guinea, Kenya, Lesotho, Mongolia, Nigeria, Philippines, Sudan, Swaziland, Togo, Trinidad \& Tobago, Venezuela, and DR Congo. In this appendix, we contrast the findings from the one-sided design in the text with a more common two-sided design.

For the two-sided design, we modify (10) to allow age trends above and below the minimum age of employment.

$$
y_{i c}=\beta_{0}^{c}+\Delta_{c u t}^{c} * 1\left(A_{i} \geq A_{c u t}^{c}\right)+\pi_{c}^{0}\left(A_{i} ; A_{i}<A_{c u t}^{c}\right)+\pi_{c}^{1}\left(A_{i} ; A_{i} \geq A_{c u t}^{c}\right)+\varepsilon_{i c}
$$

$1\left(A_{i} \geq A_{\text {cut }}^{c}\right)$ is an indicator function that is 1 if age $i$ is at or above the age of relaxation of the minimum age regulation. $\pi_{c}^{0}\left(A_{i} ; A_{i}<A_{c u t}^{c}\right)$ is a polynomial in age for ages below the minimum age. $\pi_{c}^{1}\left(A_{i} ; A_{i} \geq A_{c u t}^{c}\right)$ is a polynomial in age for ages at and above the minimum age. With age defined relative to the minimum age as in (10), is the counterfactual of what $y_{i c}$ would be if minimum age laws were extended an additional year. $\Delta_{c u t}^{c}$ is the change in $y_{i c}$ at the minimum age of employment. The difference between estimated in equation (12) and $D_{c u t}^{c}$ computed from equation (11) is that in equation (12) is smoothed using the polynomial estimated on ages where the minimum age regulation is relaxed. As with the one-sided RD design in (11), we estimate (12) on the age-cell data. We also follow the same AIC approach as the one-sided design to choose the order of the polynomials used to estimate both sides of the age trends in (12). 
Appendix Table 1 contains the results of estimating equation (12) and equation (10) for the five countries with light work regulation and paid employment data for ages that allow us to estimate (12). Column two of the table clarifies whether the two-sided estimate of equation (12) is used, marked " 2 ". The one-sided estimates of equation (10) in the appendix table are marked with a "1" and are reproductions of our findings in Table 5. Differences in estimates of the impact of permitting light work on paid employment between the two approaches are minor. In general, most differences are less than half a percentage point and never statistically significant. Differences between estimation approaches can be larger in other time allocation measures, but they do not change the flavor our results. In general, the data are not consistent with effects of light age regulation on time allocation except in Trinidad \& Tobago, regardless of the two empirical approaches used.

Appendix Table 2 mimics Appendix Table 1, but for estimates of the impact of permitting non-hazardous work. The results using the one-sided approach of equation (10) are identical to table 6A and 6B. As we saw with light work, the two different approaches have negligible effects on our estimates of the impact of allowing non-hazardous work on the prevalence of paid employment. Where the one-sided approach in the text suggested an impact on paid employment, the two-sided estimates do not differ more than one tenth of a percentage point (Nigeria, Swaziland, Trinidad \& Tobago). We see larger differences between estimation approaches in estimates of the impact of allowing non-hazardous work for other outcomes, but none are statistically significant. None of the differences in estimates alter our conclusion that there does not appear to be evidence in any country consistent with an impact of relaxing minimum age regulation on child time allocation. 
Figure 1: The Prevalence of Paid Employment for Children 8 - 14 in the Week Before Survey by Country

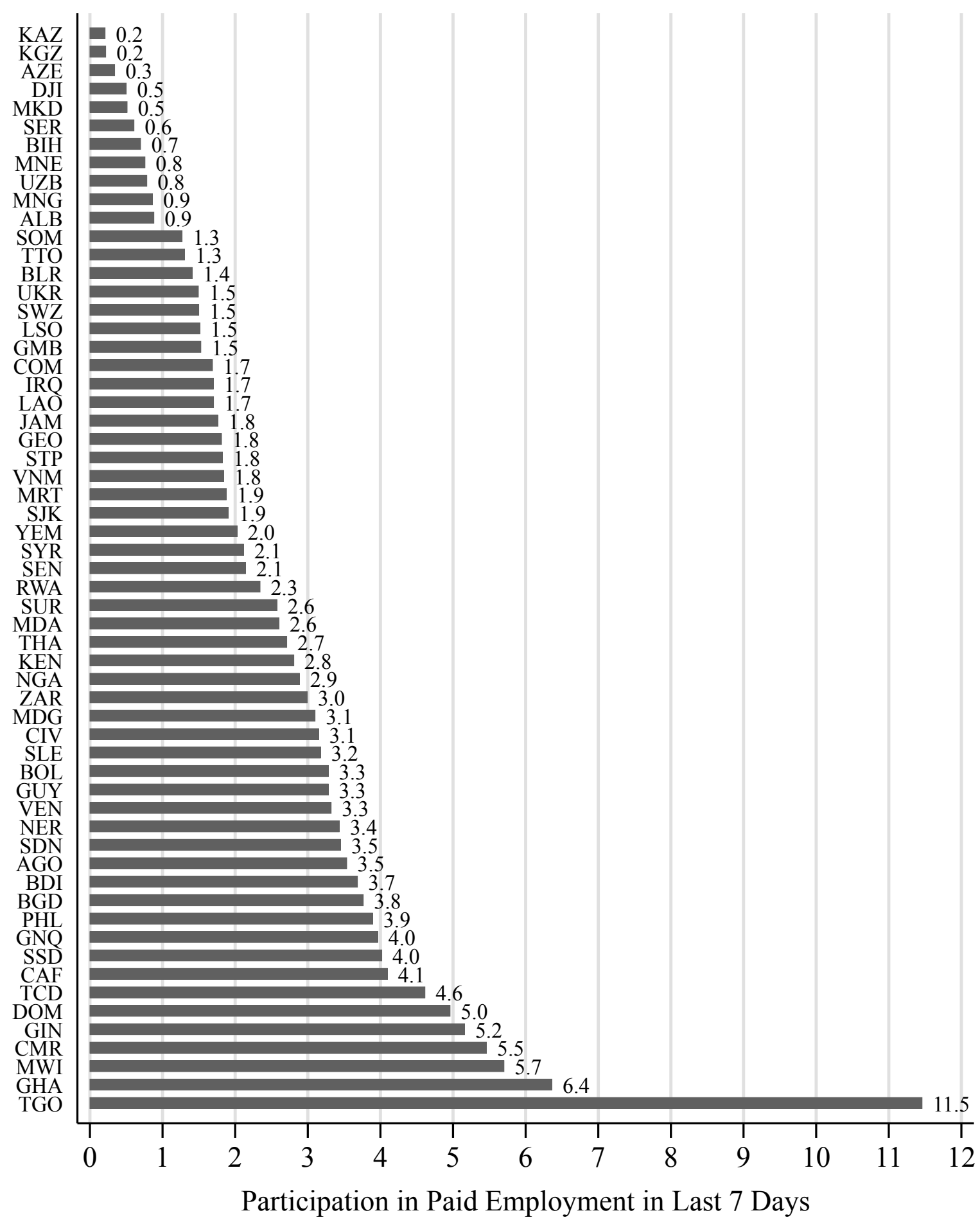


Figure 2: Fraction of Variation in Paid Employment Explained by Age

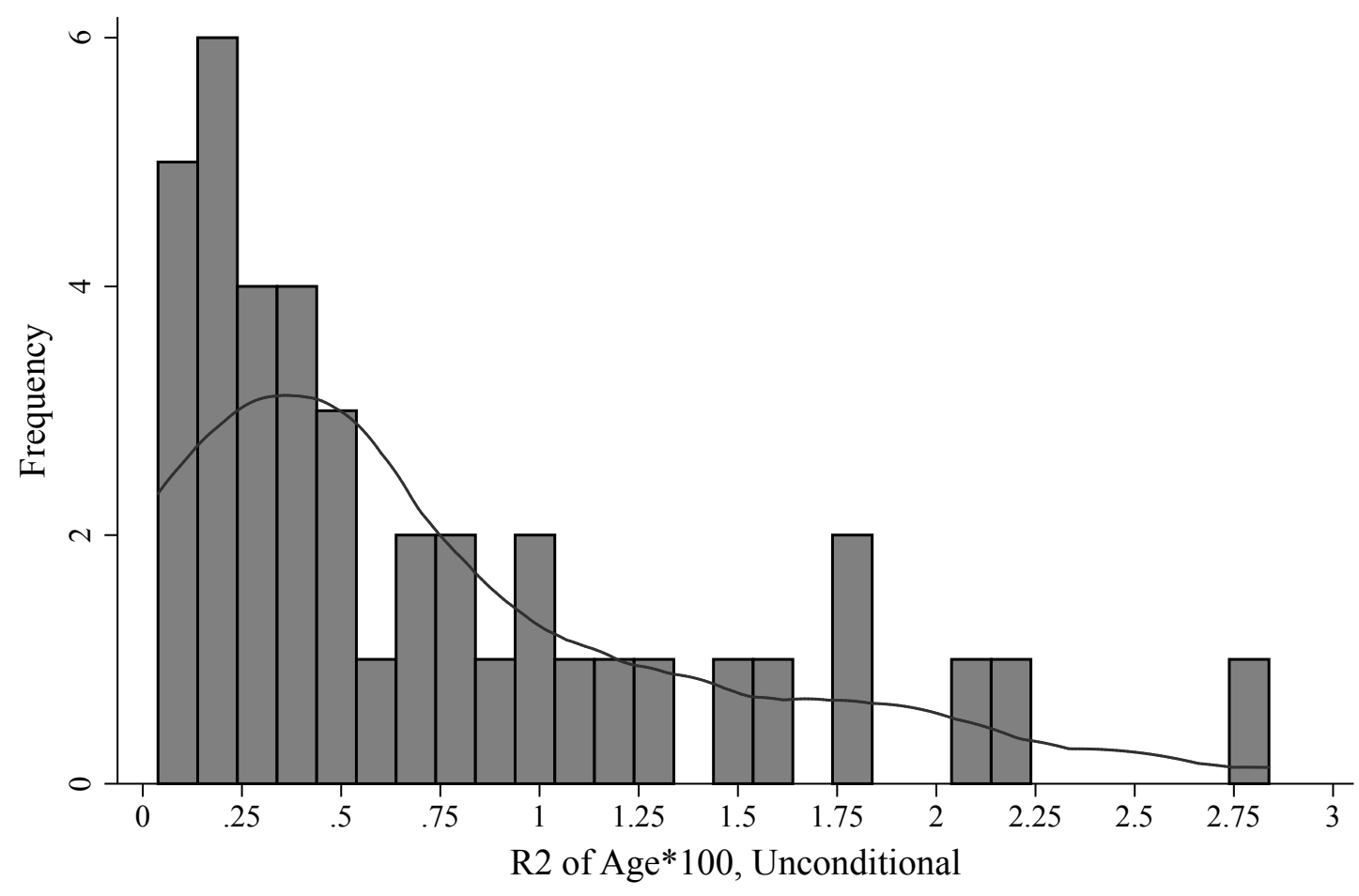

Histogram of R2 from regression of paid employment in last 7 days on age separately by country for all MICS countries with paid employment data listed in table 1. Limited to ages 8-14. Bin width is 0.1 (one tenth of one percent). Data range from 0.04 to 2.78 with a mean of 0.73 . An R2 of 1 in the picture means that 1 percent of the variation in paid employment can be explained by age. 
Figure 3: Fraction of Variation in Paid Employment Explained by Age and Household Characteristics

A. Age

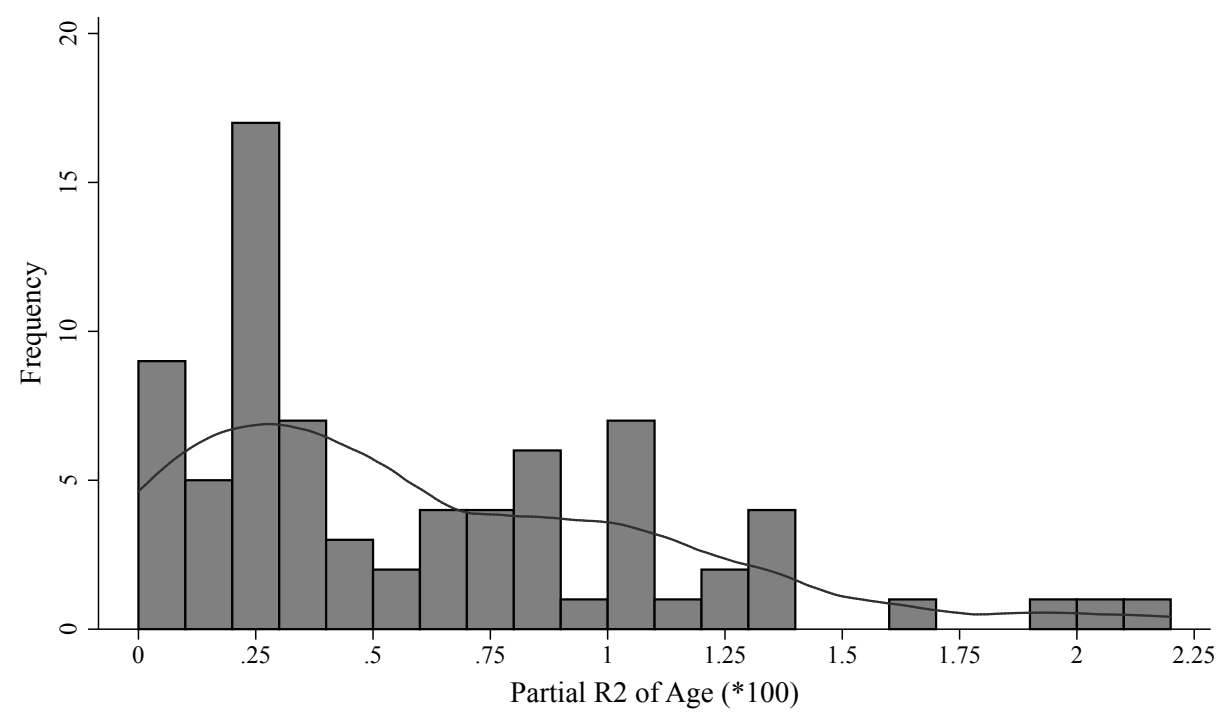

\section{B. Household Attributes}

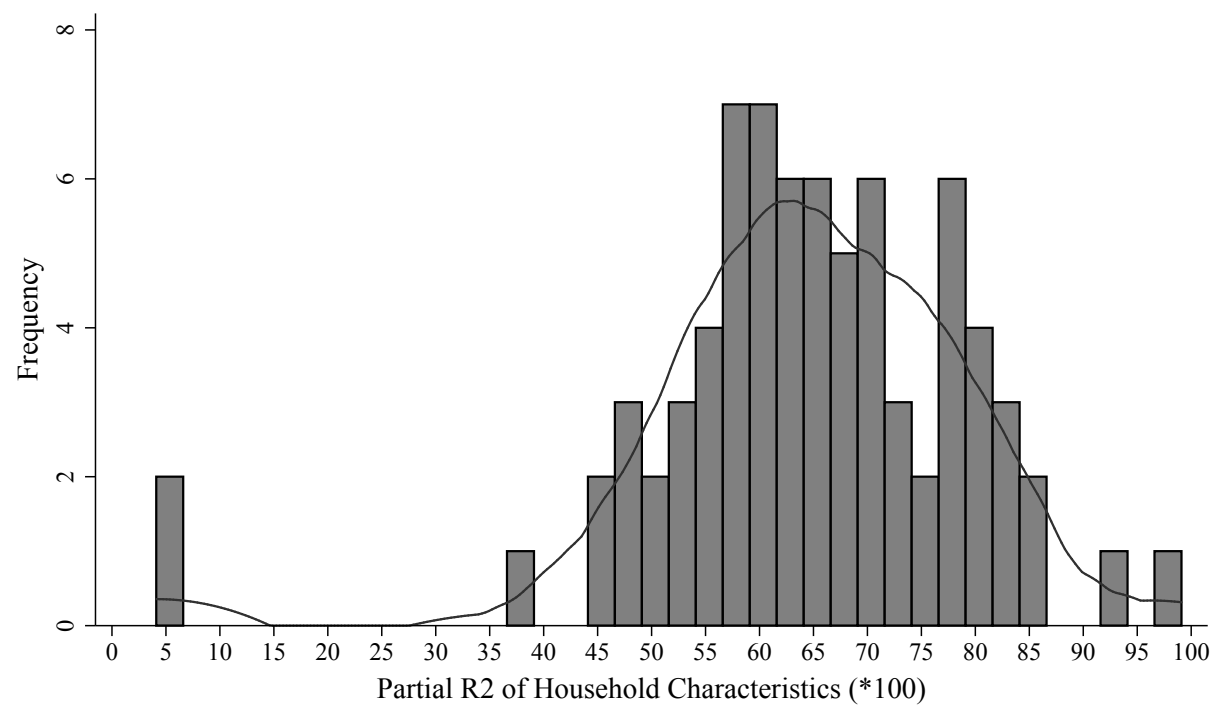

Histograms of percent of variation in paid employment for children 8-14 explained by age (panel A) and household fixed effects (panel B) in a regression of paid employment on age effects, gender, and household fixed effects. Bin width is 0.1 (one tenth of one percent) in panel A and 2.5 in panel B. A partial R2 of 1 is one percent. 
Figure 4: Change in Paid Employment with Relaxation of Light Work Restrictions

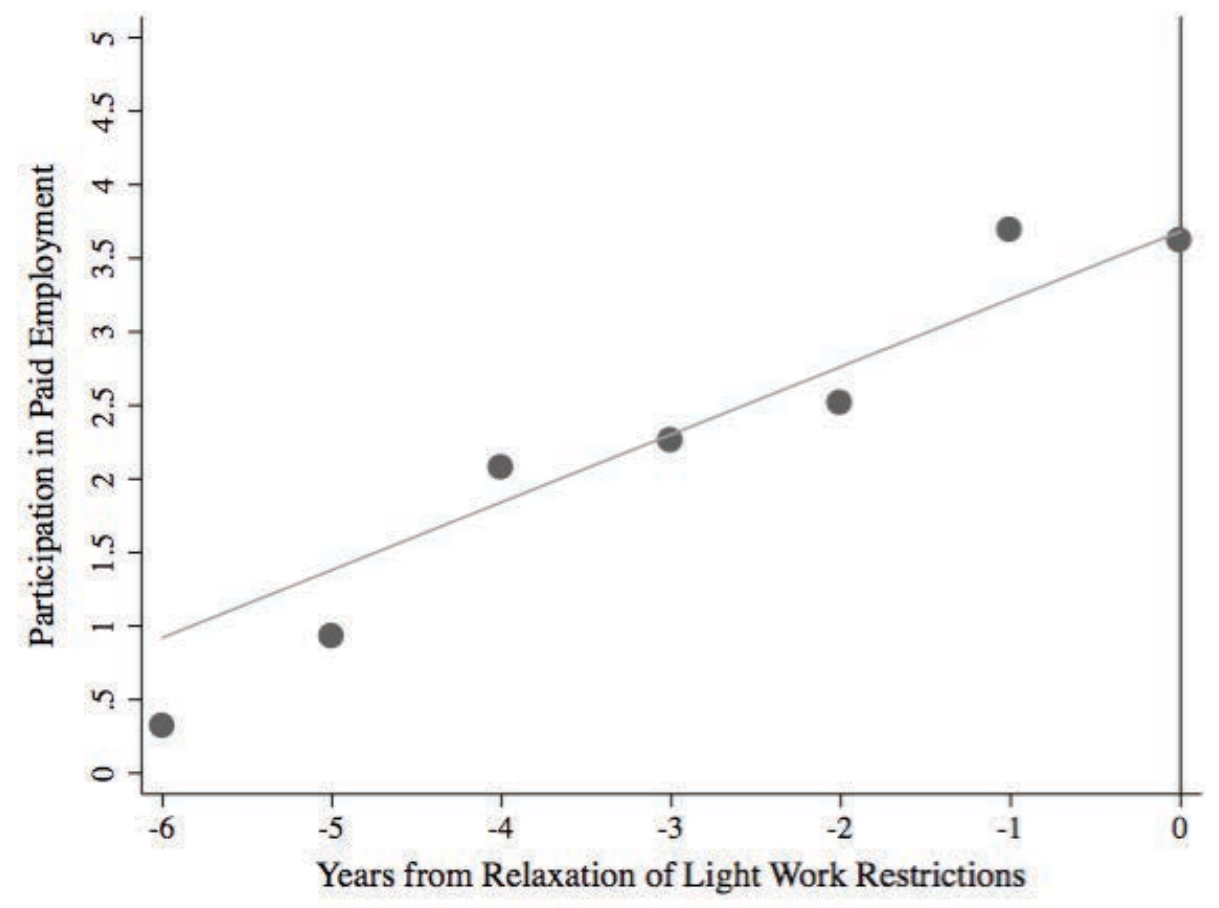


Figure 5: Change in Paid Employment and Household Based Employment at Minimum Age for Light Work by Country

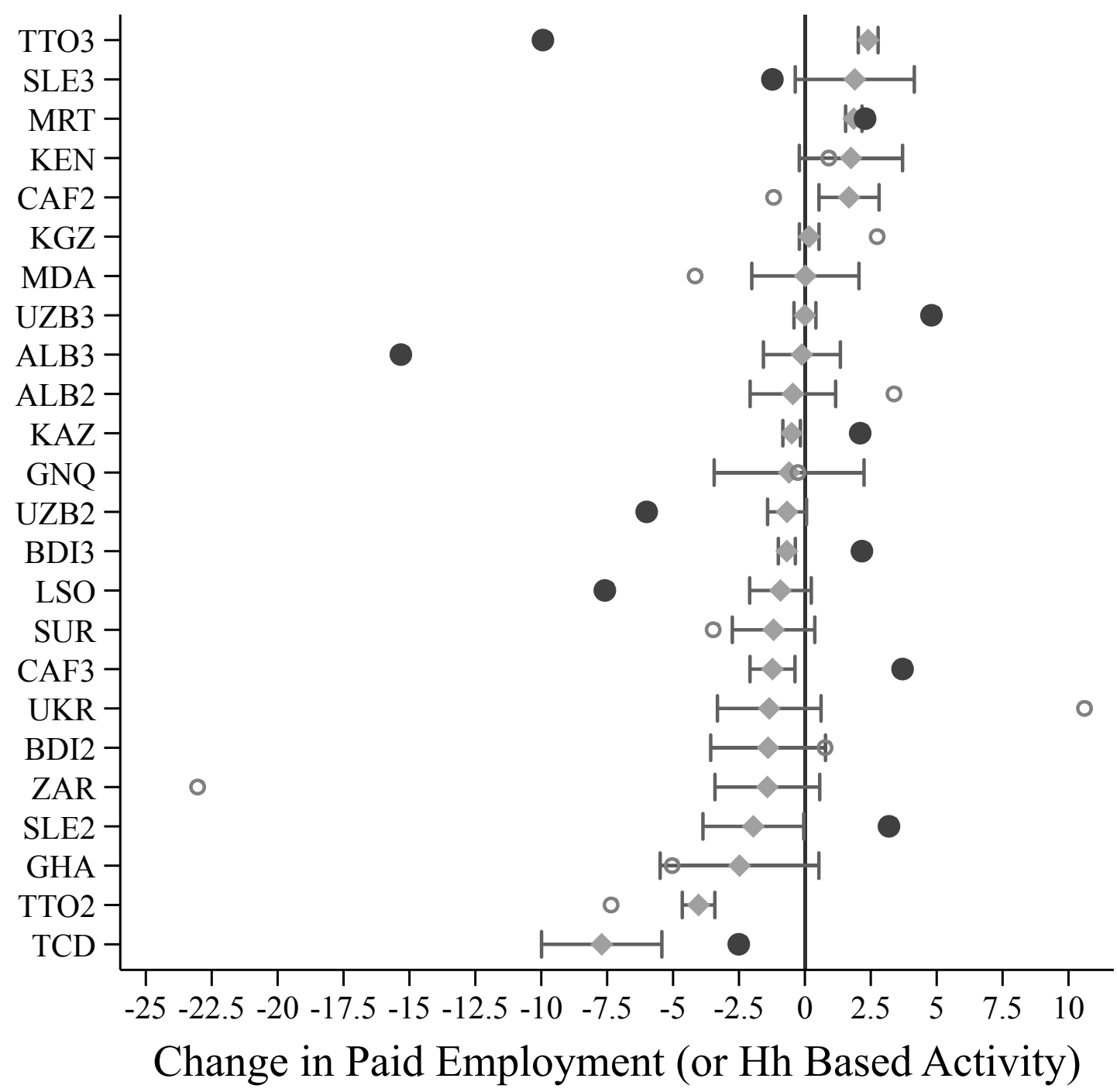

Change in paid employment at age light work is allowed (diamonds with 95 percent confidence intervals pictures) and change in household based activity at age light work is allowed (circles / filled $=$ reject null of no change with 95 percent confidence). 
Figure 6: Change in Paid Employment with Relaxation of Minimum Age for NonHazardous Work Restrictions

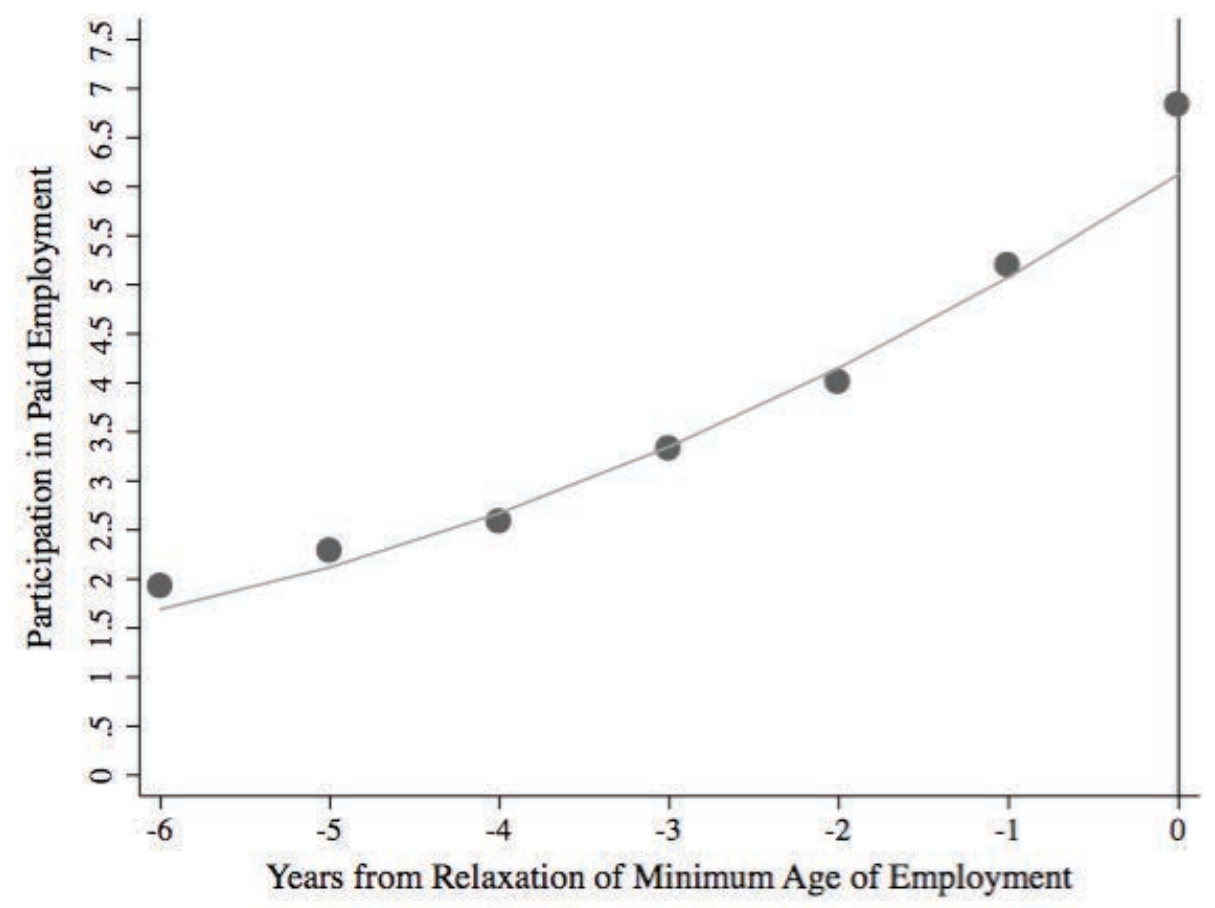


Figure 7: Change in Paid Employment and Household Based Activity at Minimum Age of Employment by Country

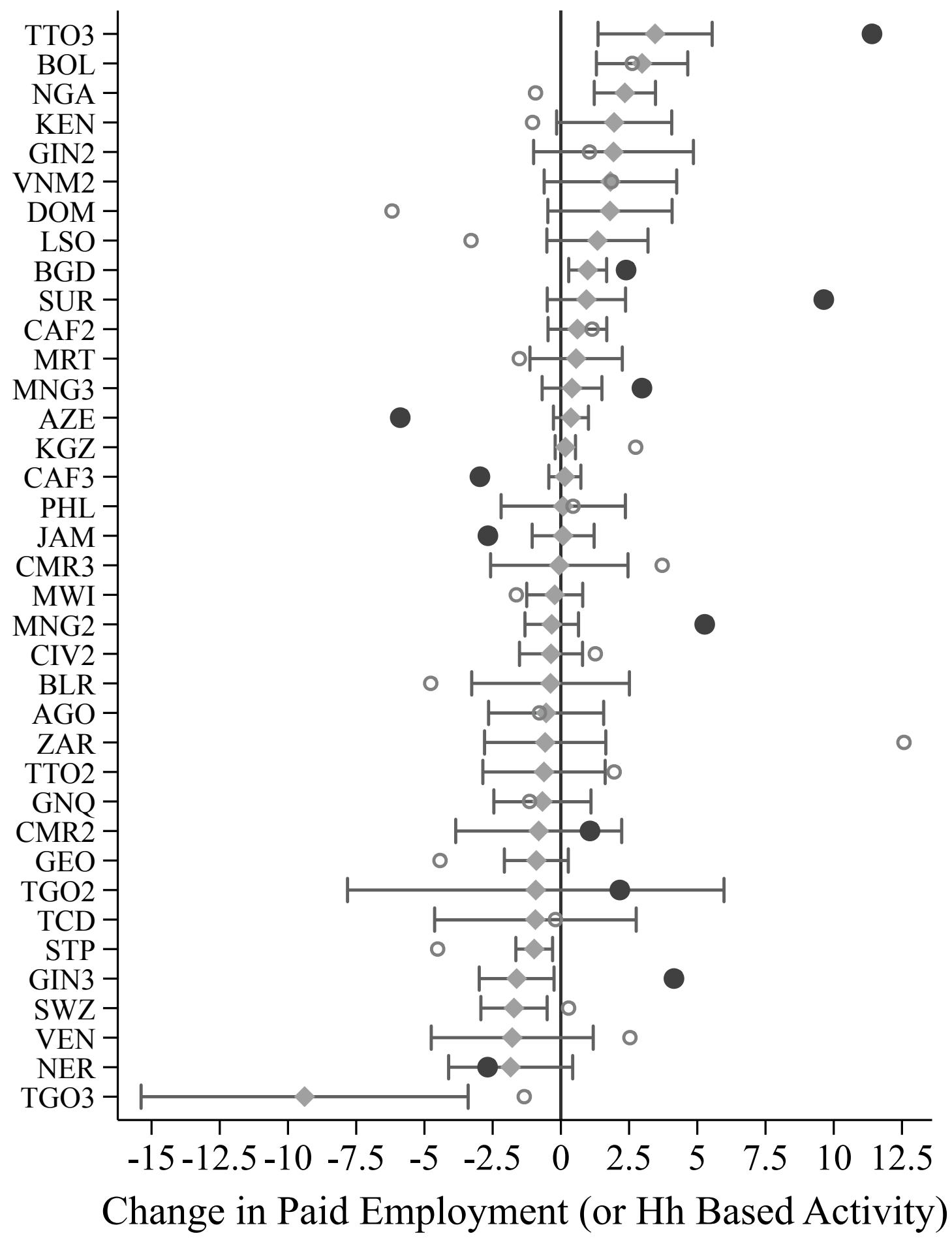

Change in paid employment at minimum age of employment (diamonds with 95 percent confidence intervals pictures) and change in household based activity at minimum age of employment (circles / filled $=$ reject null of no change at 95 percent). 
Figure 8: Relationship between Changes in Household Based Work and Paid Employment

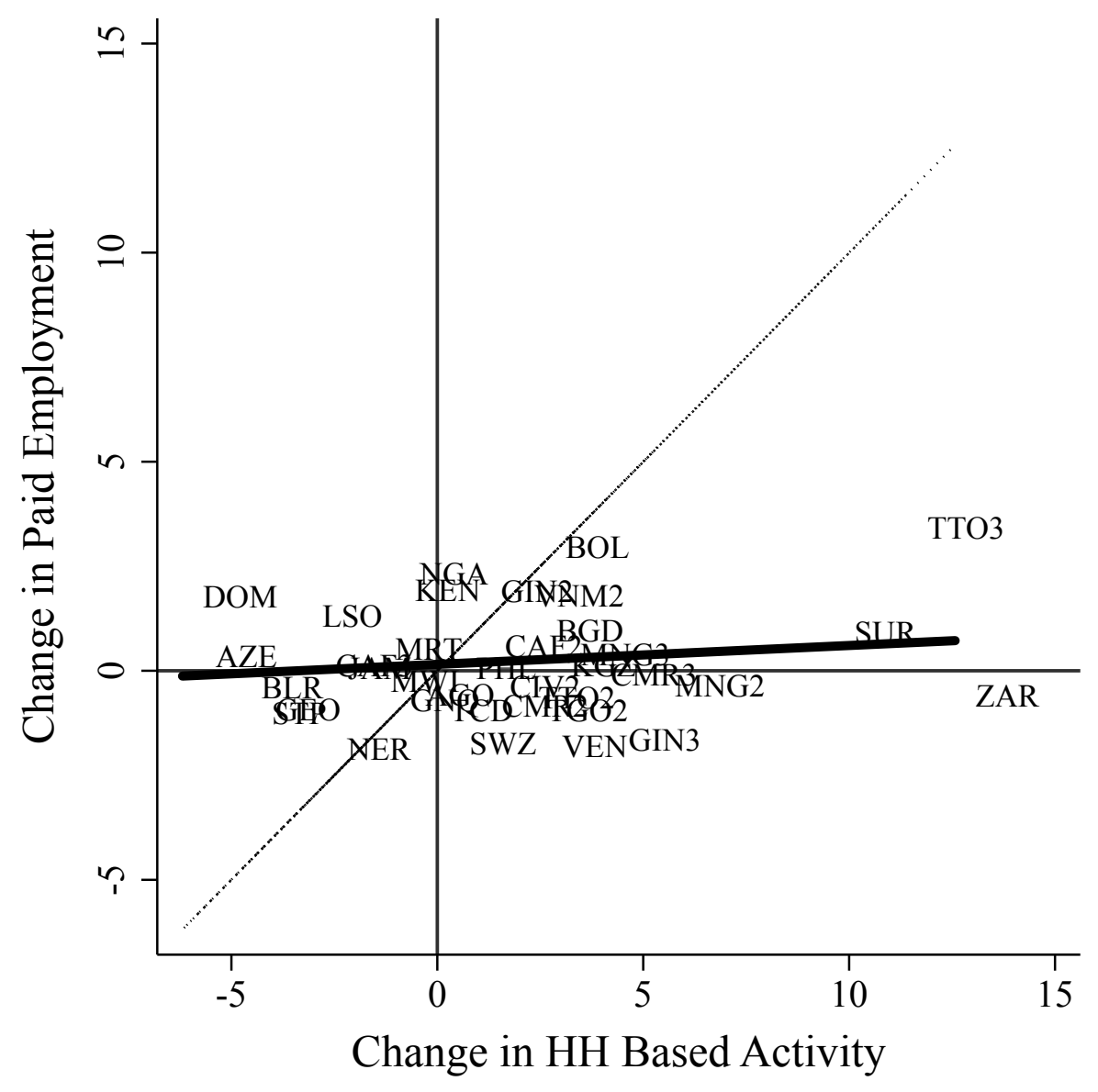

Figure plots estimated change (from trend) in household based work participation at the minimum age of employment for non-hazardous work against the estimated change in paid employment participation at the same age. "Household Based Work" combines work in the family farm or business with work in unpaid household services. Fitted regression line also pictured. One outlier in change in paid employment omitted. All countries. 
Figure 9: Change in Paid Employment with Relaxation of Min. Age for Non-Hazardous Work Restrictions by Association with Compulsory Schooling Regulation

A. Regulation Relaxes when Schooling is Not Compulsory

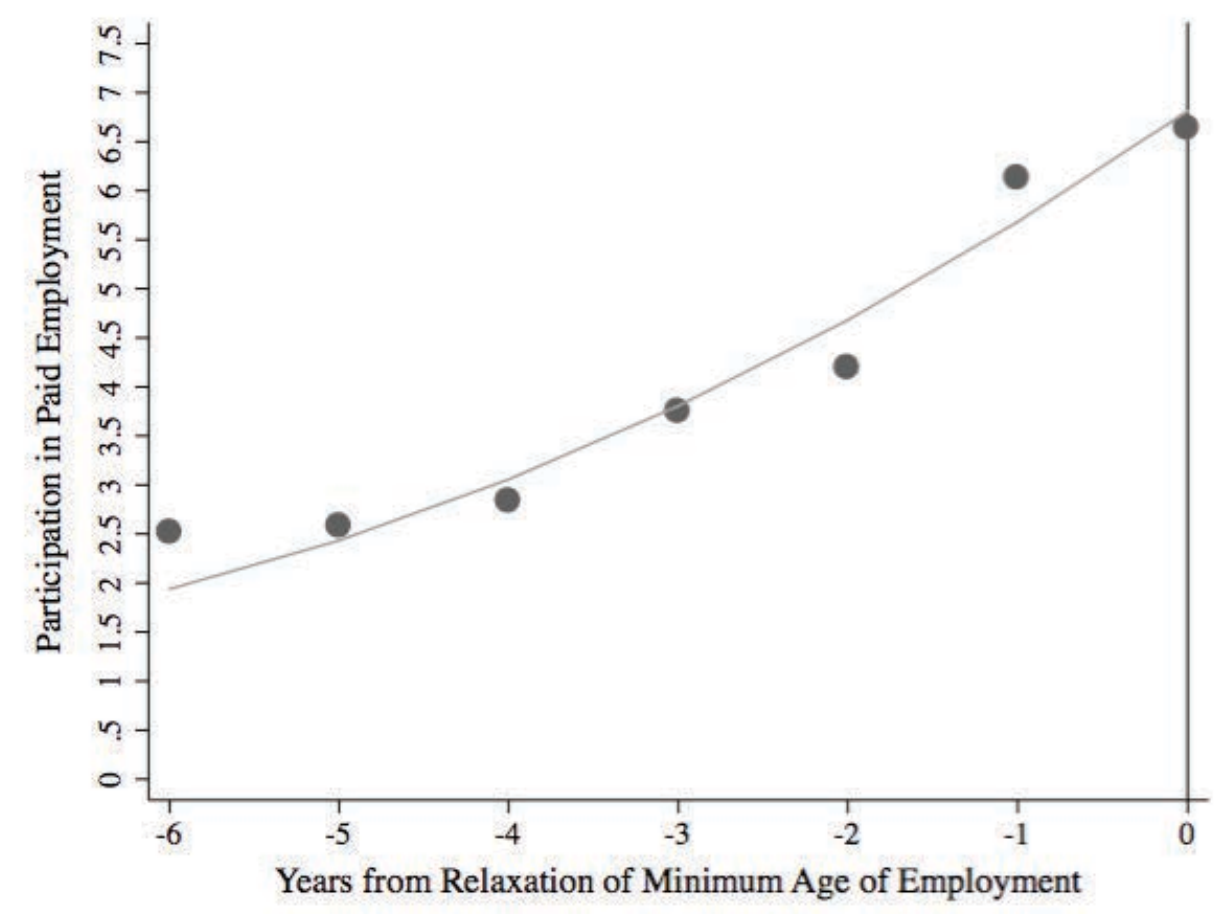

B. Regulation Relaxes at Same Time as Compulsory Schooling

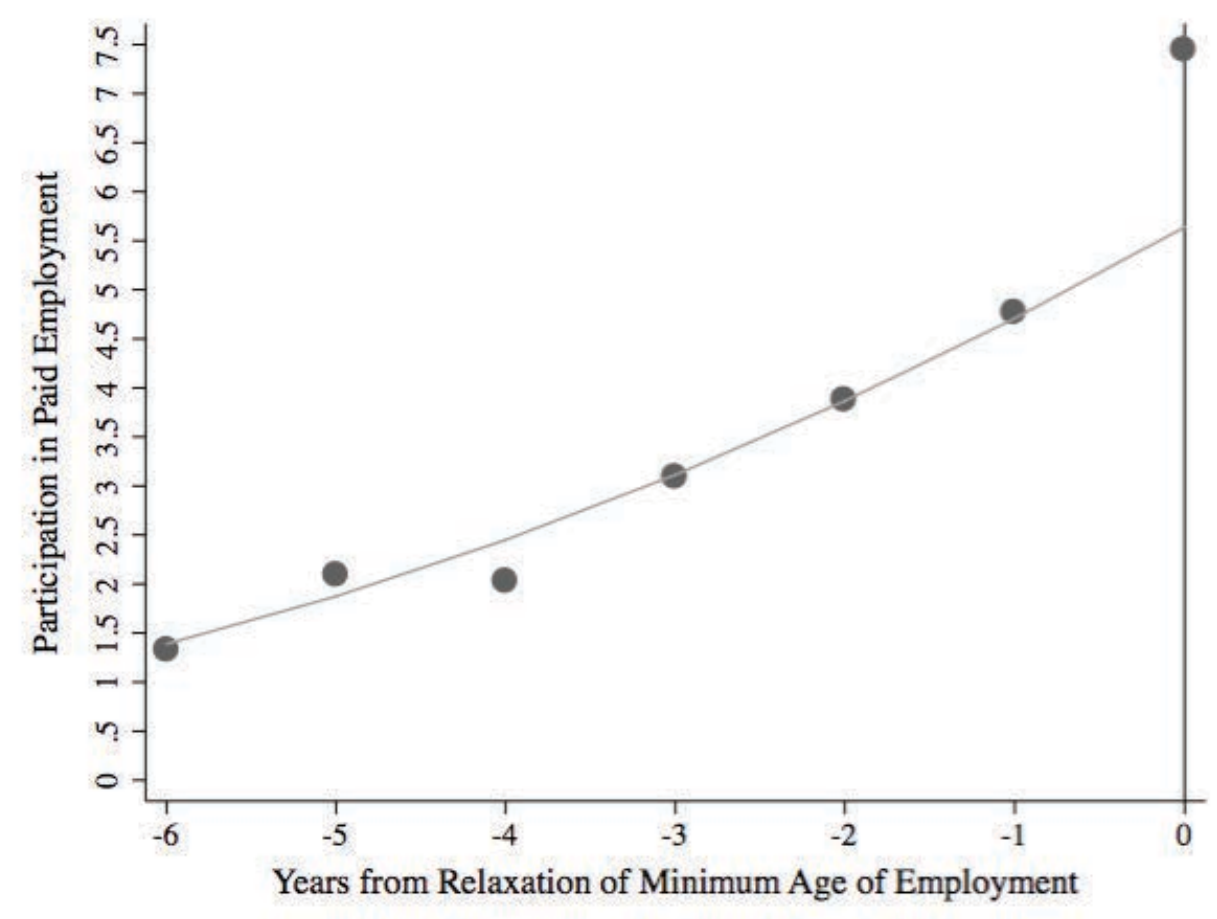




\begin{tabular}{|c|c|c|c|c|c|}
\hline \multirow[b]{2}{*}{ Country } & \multirow[b]{2}{*}{$\begin{array}{l}\text { Country } \\
\text { Code }\end{array}$} & \multirow[b]{2}{*}{$\begin{array}{l}\text { MICS } \\
\text { Round }\end{array}$} & \multicolumn{2}{|c|}{$\begin{array}{c}\text { M1n Age for } \\
\text { Employment in: }\end{array}$} & \multirow{2}{*}{$\begin{array}{l}\text { Age at which } \\
\text { schooling is no } \\
\text { longer } \\
\text { compulsory }\end{array}$} \\
\hline & & & $\begin{array}{l}\text { Non-Haz } \\
\text { Work }\end{array}$ & $\begin{array}{l}\text { Light } \\
\text { Work }\end{array}$ & \\
\hline \multicolumn{6}{|l|}{ Africa } \\
\hline Angola & $\mathrm{AGO}$ & 2 & 14 & NA & $14^{*}$ \\
\hline Burundi & BDI & $2 \& 3$ & 16 & 12 & $13^{*}$ \\
\hline Cameroon & CMR & $2 \& 3$ & 14 & NA & 15 \\
\hline Central African Republic & CAF & $2 \& 3$ & 14 & 12 & 16 \\
\hline Chad & $\mathrm{TCD}$ & 2 & 14 & 12 & $12 *$ \\
\hline Comoros & $\mathrm{COM}$ & 2 & 15 & NA & 14 \\
\hline Cote d'Ivoire & CIV & $2 \& 3$ & 14 & NA & NA \\
\hline Democratic Republic of Congo & ZAR & 2 & 16 & 14 & $14^{*}$ \\
\hline Djibouti & DJI & 3 & 16 & NA & $15^{*}$ \\
\hline Equatorial Guinea & GNQ & 2 & 14 & 12 & 14 \\
\hline Gambia & GMB2 & 2 & 18 & NA & 13 \\
\hline Gambia & GMB3 & 3 & 18 & 16 & 13 \\
\hline Ghana & GHA & 3 & 15 & 13 & $15^{*}$ \\
\hline Guinea Bissau & GIN & $2 \& 3$ & 14 & NA & 13 \\
\hline Kenya & KEN & 2 & 16 & 13 & $14^{*}$ \\
\hline Lesotho & LSO & 2 & 15 & 13 & NA \\
\hline Madagascar & MDG & 2 & 15 & NA & 15 \\
\hline Malawi & MWI & 3 & 14 & NA & NA \\
\hline Mauritania & MRT & 3 & 14 & 12 & $15^{*}$ \\
\hline Niger & NER & 2 & 14 & NA & $13^{*}$ \\
\hline Nigeria & NGA & 3 & 15 & NA & $15^{*}$ \\
\hline Rwanda & RWA & 2 & 18 & NA & $13^{*}$ \\
\hline Sao Tome and Principe & STP & 2 & 14 & NA & $13^{*}$ \\
\hline Senegal & SEN & 2 & 16 & NA & 17 \\
\hline Sierra Leone & SLE & $2 \& 3$ & 15 & 12 & $12 *$ \\
\hline Somalia & SOM & 3 & NA & NA & 14 \\
\hline Sudan (North) & SDN & 2 & 18 & NA & $14^{*}$ \\
\hline Sudan (South) & SSD & 2 & 18 & NA & $14^{*}$ \\
\hline Swaziland & SWZ & 2 & 15 & NA & NA \\
\hline Togo & TGO & 2 & 14 & NA & 16 \\
\hline \multicolumn{6}{|l|}{ Europe and Central Asia } \\
\hline Albania & ALB & $2 \& 3$ & 16 & 14 & $14 *$ \\
\hline Azerbaijan & AZE & 2 & 14 & NA & 17 \\
\hline Belarus & BLR & 3 & 14 & NA & $15^{*}$ \\
\hline Bosnia and Herzegovina & $\mathrm{BIH}$ & $2 \& 3$ & 15 & NA & 15 \\
\hline Georgia & GEO & 3 & 14 & NA & $15^{*}$ \\
\hline Kazakhstan & $\mathrm{KAZ}$ & 3 & 15 & 14 & $18^{*}$ \\
\hline Kyrgyzstan & KGZ & 3 & 14 & 14 & $16^{*}$ \\
\hline Macedonia & MKD & 3 & 15 & NA & $15^{*}$ \\
\hline Moldova & MDA & 2 & 16 & 14 & $16^{*}$ \\
\hline Montenegro & MNE & 3 & 15 & NA & $15^{*}$ \\
\hline Serbia & SER & 3 & 15 & NA & $15^{*}$ \\
\hline
\end{tabular}


Table 1: Minimum Age of Employment \& Compulsory Schooling Laws by Country

\begin{tabular}{|c|c|c|c|c|c|}
\hline \multirow[b]{2}{*}{ Country } & \multirow[b]{2}{*}{$\begin{array}{l}\text { Country } \\
\text { Code }\end{array}$} & \multirow[b]{2}{*}{$\begin{array}{l}\text { MICS } \\
\text { Round }\end{array}$} & \multicolumn{2}{|c|}{$\begin{array}{c}\text { Min Age for } \\
\text { Employment in: }\end{array}$} & \multirow{2}{*}{$\begin{array}{c}\text { Age at which } \\
\text { schooling is no } \\
\text { longer } \\
\text { compulsory }\end{array}$} \\
\hline & & & $\begin{array}{l}\text { Non-Haz } \\
\text { Work }\end{array}$ & $\begin{array}{l}\text { Light } \\
\text { Work }\end{array}$ & \\
\hline Tajikistan & SJK & $2 \& 3$ & 16 & 7 & 16 \\
\hline Ukraine & UKR & 3 & 15 & 14 & $18^{*}$ \\
\hline Uzbekistan & UZB2 & 2 & 16 & 14 & $18^{*}$ \\
\hline Uzbekistan & UZB3 & 3 & 16 & 14 & $19^{*}$ \\
\hline \multicolumn{6}{|l|}{ East Asia and the Pacific } \\
\hline Laos & $\mathrm{LAO}$ & $2 \& 3$ & 15 & NA & $11 *$ \\
\hline Mongolia & MNG2 & 2 & 14 & NA & $16^{*}$ \\
\hline Mongolia & MNG3 & 3 & 14 & NA & $17^{*}$ \\
\hline Philippines & PHL & 2 & 15 & NA & $12 *$ \\
\hline Thailand & THA & 3 & 15 & NA & $15^{*}$ \\
\hline Vietnam & VNM & $2 \& 3$ & 15 & NA & 15 \\
\hline \multicolumn{6}{|c|}{ Middle East and North Africa } \\
\hline Iraq & IRQ & $2 \& 3$ & 15 & NA & $12 *$ \\
\hline Syria & SYR & 3 & 15 & NA & $15^{*}$ \\
\hline Yemen & YEM & 3 & 15 & NA & 15 \\
\hline \multicolumn{6}{|l|}{ South Asia } \\
\hline Bangladesh & BGD & 3 & 12 & NA & 11 \\
\hline \multicolumn{6}{|c|}{ Latin America \& the Carribean } \\
\hline Bolivia & BOL & 2 & 14 & NA & $14^{*}$ \\
\hline Dominican Republic & DOM & 2 & 14 & NA & $14^{*}$ \\
\hline Guyana & GUY & $2 \& 3$ & 15 & NA & 15 \\
\hline Jamaica & JAM & $2 \& 3$ & 12 & NA & 12 \\
\hline Suriname & SUR & $2 \& 3$ & 14 & 12 & 12 \\
\hline Trinidad and Tobago & TTO2 & 2 & 14 & 12 & 12 \\
\hline Trinidad and Tobago & TTO3 & 3 & 16 & 14 & 12 \\
\hline Venezuela & VEN & 2 & 14 & NA & 17 \\
\hline
\end{tabular}

NA = No applicable law. The non-hazardous column is the minimum age of employment in the country, defined as the youngest age at which it is legal to pay a child to work full time outside the home (during the day, limited hours). The light work age is the youngest age at which a child may work for limited hours, during the day in traditional or family activities. Age at which child has completed compulsory schooling is the age at which the child is no longer required to go to school. When compulsory schooling is stipulated by grade, we impute the age based on the scheduled progression through grades. ${ }^{*}=$ restriction is based on grade completion (ages are imputed based on scheduled school progression). See Appendix 1 for country level detail. In general, information on minimum age of employment comes from USDOL Trade and Development Act reports. Age at the end of compulsory schooling information is from the Right to Education project. Note: All ages are when restrictions are no longer in place. Thus, if schooling is compulsory through age 12, age 13 is when the child has completed compulsory schooling. That is, if schooling is compulsory through age 12 , the column will read age 13 , the age at which schooling is no longer compulsory. 
Table 2: Participation in the Last 7 Days in Various Activities

Restricted to Ages 8-14

\begin{tabular}{|c|c|c|c|c|c|}
\hline & \multirow[b]{2}{*}{ Full Sample } & \multicolumn{2}{|c|}{ Survey Round } & \multicolumn{2}{|c|}{$\begin{array}{l}\text { Region } \\
\text { Sub-Saharan }\end{array}$} \\
\hline & & MICS2 & MICS3 & Africa & Rest of World \\
\hline Population in Millions & 156 & 72 & 84 & 72 & 85 \\
\hline Paid Employment & 2.95 & 3.08 & 2.85 & 3.60 & 2.42 \\
\hline Unpaid Economic Activity & 26.23 & 26.78 & 25.76 & 37.20 & 17.05 \\
\hline Economically Active & 27.98 & 28.61 & 27.45 & 38.82 & 18.91 \\
\hline Unpaid Househld Services & 74.91 & 76.78 & 73.35 & 78.60 & 71.84 \\
\hline Househld Based Activity & 78.38 & 80.23 & 76.84 & 82.06 & 75.31 \\
\hline Any Type of Work & 79.54 & 80.81 & 78.48 & 83.46 & 76.27 \\
\hline Attends School in Last Year & 81.49 & 80.83 & 82.05 & 71.66 & 89.69 \\
\hline No School nor Any Type of Work & 3.58 & 3.16 & 3.93 & 5.44 & 2.05 \\
\hline
\end{tabular}


Table 2A: Participation in the Last 7 Days in Various Activities by Country, Africa

Restricted to Ages 8-14

\begin{tabular}{|c|c|c|c|c|c|c|c|c|c|c|c|c|c|}
\hline Country & $\begin{array}{l}\text { MICS } \\
\text { Round }\end{array}$ & $\begin{array}{c}\text { Sample Size } \\
\text { (for } \\
\text { activities) }\end{array}$ & $\begin{array}{l}\text { Pop. in 000s } \\
\text { (for } \\
\text { activities) }\end{array}$ & $\begin{array}{c}\text { Paid } \\
\text { Employ. }\end{array}$ & $\begin{array}{l}\text { Unpaid } \\
\text { Econ. } \\
\text { Activity }\end{array}$ & $\begin{array}{l}\text { Econ. } \\
\text { Active }\end{array}$ & $\begin{array}{l}\text { Unpaid } \\
\text { Househld } \\
\text { Services }\end{array}$ & $\begin{array}{l}\text { Househld } \\
\text { Based } \\
\text { Activity }\end{array}$ & $\begin{array}{l}\text { Any Type } \\
\text { of Work }\end{array}$ & $\begin{array}{l}\text { Attends } \\
\text { School in } \\
\text { Last Year }\end{array}$ & $\begin{array}{c}\text { No School } \\
\text { nor Any } \\
\text { Type of } \\
\text { Work }\end{array}$ & $\begin{array}{l}\text { Max Age } \\
\text { for } \\
\text { Activities } \\
\text { Data }\end{array}$ & $\begin{array}{c}\text { Max Age } \\
\text { for } \\
\text { Schooling } \\
\text { Data }\end{array}$ \\
\hline Angola & 2 & 5,879 & $2,113,540$ & 3.5 & 29.9 & 31.9 & 87.6 & 88.4 & 88.8 & 78.6 & 3.4 & 14 & 17 \\
\hline Burundi & 2 & 4,434 & $1,021,441$ & 3.4 & 38.6 & 40.2 & 91.8 & 94.1 & 94.7 & 87.8 & 0.7 & 14 & 17 \\
\hline Burundi & 3 & 8,571 & $1,073,840$ & 3.9 & 9.1 & 12.4 & 92.9 & 93.3 & 93.8 & 74.7 & 1.7 & 14 & 17 \\
\hline Cameroon & 2 & 4,548 & $2,352,511$ & 6.7 & 62.7 & 65.4 & 86.7 & 90.9 & 91.6 & 82.7 & 1.3 & 14 & 17 \\
\hline Cameroon & 3 & 8,084 & $2,479,599$ & 4.3 & 37.8 & 40.3 & 91.1 & 93.0 & 93.5 & 84.8 & 1.4 & 14 & 17 \\
\hline Central African Republic & 2 & 20,837 & 532,845 & 4.3 & 68.7 & 70.1 & 91.1 & 93.7 & 94.8 & 53.3 & 1.9 & 14 & 17 \\
\hline Central African Republic & 3 & 9,160 & 553,614 & 3.9 & 58.4 & 59.3 & 85.3 & 89.1 & 90.9 & 65.4 & 3.2 & 14 & 17 \\
\hline Chad & 2 & 5,771 & $1,208,280$ & 4.6 & 73.1 & 73.6 & 87.8 & 93.9 & 94.3 & 59.5 & 1.8 & 14 & 17 \\
\hline Comoros & 2 & 4,742 & 75,075 & 1.7 & 42.5 & 43.2 & 68.1 & 74.7 & 74.4 & 59.6 & 10.4 & 14 & 17 \\
\hline Cote d'Ivoire & 2 & 10,965 & $2,396,356$ & 2.7 & 42.2 & 43.1 & 77.3 & 85.6 & 85.7 & 66.4 & 3.2 & 14 & 17 \\
\hline Cote d'Ivoire & 3 & 10,543 & $2,493,458$ & 3.6 & 46.7 & 47.9 & 62.7 & 72.8 & 73.7 & 64.2 & 6.3 & 14 & 17 \\
\hline DR Congo & 2 & 10,704 & $7,616,897$ & 3.0 & 26.9 & 28.5 & 74.8 & 77.0 & 77.8 & 65.7 & 8.4 & 17 & 17 \\
\hline Djibouti & 3 & 4,754 & 109,892 & 0.5 & 13.3 & 13.6 & 32.5 & 34.5 & 40.5 & 81.3 & 11.2 & 14 & 17 \\
\hline Equatorial Guinea & 2 & 3,943 & 76,294 & 4.0 & 37.9 & 40.2 & 91.6 & 92.9 & 92.8 & 92.9 & 0.8 & 17 & 17 \\
\hline Gambia & 3 & 9,003 & 222,774 & 1.2 & 46.4 & 46.7 & 74.9 & 78.0 & 78.4 & 74.4 & 5.0 & 14 & 17 \\
\hline Ghana & 3 & 5,052 & $2,941,884$ & 6.4 & 48.5 & 51.5 & 86.3 & 88.9 & 89.6 & 86.2 & 1.3 & 14 & 17 \\
\hline Guinea Bissau & 2 & 6,305 & 172,365 & 6.4 & 68.8 & 69.4 & 82.1 & 91.9 & 92.0 & 47.9 & 4.1 & 14 & 17 \\
\hline Guinea Bissau & 3 & 7,549 & 192,889 & 4.0 & 50.1 & 52.1 & 83.1 & 89.2 & 89.8 & 69.9 & 3.2 & 14 & 17 \\
\hline Kenya & 2 & 7,892 & $4,980,410$ & 2.8 & 1.2 & 3.6 & 74.2 & 74.5 & 75.1 & 91.4 & 2.4 & 17 & 17 \\
\hline Lesotho & 2 & 6,077 & 303,250 & 1.5 & 23.0 & 23.9 & 78.5 & 80.6 & 81.4 & 89.2 & 2.8 & 17 & 17 \\
\hline Madagascar & 2 & 5,506 & $2,245,225$ & 3.1 & 27.9 & 29.6 & 84.4 & 90.3 & 90.8 & 68.0 & 3.0 & 14 & 17 \\
\hline Malawi & 3 & 27,140 & $2,037,906$ & 5.7 & 40.8 & 43.6 & 88.6 & 90.3 & 90.8 & 89.5 & 2.0 & 14 & 17 \\
\hline Mauritania & 3 & 11,307 & 413,410 & 1.9 & 21.6 & 22.9 & 56.8 & 60.8 & 61.8 & 77.4 & 6.9 & 14 & 17 \\
\hline Niger & 2 & 4,765 & $1,619,285$ & 3.4 & 73.8 & 75.1 & 92.2 & 96.6 & 97.1 & 43.2 & 1.0 & 14 & 17 \\
\hline Nigeria & 3 & 25,042 & $19,600,000$ & 2.9 & 41.5 & 42.4 & 76.5 & 79.7 & 83.1 & 67.5 & 8.8 & 17 & 17 \\
\hline Rwanda & 2 & 4,161 & $1,232,019$ & 2.3 & 35.2 & 36.3 & 91.6 & 92.9 & 94.1 & 76.0 & 1.7 & 15 & 17 \\
\hline Sao Tome and Principe & 2 & 2,741 & 20,886 & 1.8 & 17.2 & 18.3 & 89.2 & 90.2 & 90.6 & 86.4 & 1.3 & 14 & 17 \\
\hline Senegal & 2 & 11,627 & $1,446,208$ & 2.1 & 36.2 & 37.8 & 89.5 & 94.0 & 94.5 & 55.7 & 2.0 & 14 & 17 \\
\hline Sierra Leone & 2 & 4,169 & 538,618 & 1.8 & 77.5 & 77.9 & 91.2 & 94.4 & 94.7 & 49.4 & 3.3 & 14 & 17 \\
\hline Sierra Leone & 3 & 7,991 & 709,831 & 4.1 & 63.1 & 63.8 & 89.4 & 94.4 & 95.1 & 75.2 & 1.4 & 14 & 17 \\
\hline Somalia & 3 & 6,434 & $1,165,278$ & 1.3 & 44.6 & 44.9 & 74.2 & 82.3 & 82.5 & 58.3 & 5.9 & 14 & 17 \\
\hline Sudan, Northern & 2 & 28,069 & $4,535,440$ & 3.5 & 19.4 & 21.0 & 60.9 & 65.3 & 65.9 & 70.2 & 9.1 & 17 & 17 \\
\hline Togo & 2 & 5,203 & 736,168 & 16.6 & 71.7 & 77.5 & 92.5 & 95.8 & 96.4 & 74.0 & 1.1 & 17 & 17 \\
\hline Togo & 3 & 6,683 & 784,670 & 6.7 & 41.3 & 45.1 & 85.7 & 89.4 & 90.4 & 80.3 & 2.3 & 14 & 17 \\
\hline
\end{tabular}


Table 2B: Participation in the Last 7 Days in Various Activities by Country, Non-Africa

Restricted to Ages 8-14

\begin{tabular}{|c|c|c|c|c|c|c|c|c|c|c|c|c|c|}
\hline Country & $\begin{array}{l}\text { MICS } \\
\text { Round }\end{array}$ & $\begin{array}{c}\text { Sample Size } \\
\text { (for } \\
\text { activities) }\end{array}$ & $\begin{array}{l}\text { Pop. in 000s } \\
\text { (for } \\
\text { activities) }\end{array}$ & $\begin{array}{c}\text { Paid } \\
\text { Employ. }\end{array}$ & $\begin{array}{l}\text { Unpaid } \\
\text { Econ. } \\
\text { Activity }\end{array}$ & $\begin{array}{l}\text { Econ. } \\
\text { Active }\end{array}$ & $\begin{array}{l}\text { Unpaid } \\
\text { Househld } \\
\text { Services }\end{array}$ & $\begin{array}{l}\text { Househld } \\
\text { Based } \\
\text { Activity }\end{array}$ & $\begin{array}{l}\text { Any Type } \\
\text { of Work }\end{array}$ & $\begin{array}{l}\text { Attends } \\
\text { School in } \\
\text { Last Year }\end{array}$ & $\begin{array}{l}\text { No School } \\
\text { nor Any } \\
\text { Type of } \\
\text { Work }\end{array}$ & $\begin{array}{l}\text { Max Age } \\
\text { for } \\
\text { Activities } \\
\text { Data }\end{array}$ & $\begin{array}{c}\text { Max Age } \\
\text { for } \\
\text { Schooling } \\
\text { Data }\end{array}$ \\
\hline Albania & 2 & 3,018 & 336,538 & 1.2 & 38.8 & 39.3 & 68.3 & 75.5 & 76.2 & 54.3 & 11.8 & 14 & 17 \\
\hline Albania & 3 & 2,726 & 307,224 & 0.6 & 23.2 & 23.5 & 54.3 & 60.9 & 61.4 & 96.8 & 0.9 & 14 & 18 \\
\hline Azerbaijan & 2 & 4,398 & 967,220 & 0.3 & 10.0 & 10.2 & 70.4 & 71.7 & 72.3 & 96.6 & 1.5 & 14 & 17 \\
\hline Bangladesh & 3 & 49,692 & $15,800,000$ & 3.8 & 14.8 & 18.0 & 67.9 & 73.7 & 76.3 & 81.8 & 2.7 & 14 & 18 \\
\hline Belarus & 3 & 1,684 & 512,552 & 1.4 & 11.5 & 12.6 & 80.2 & 81.3 & 81.6 & 99.7 & 0.3 & 14 & 18 \\
\hline Bolivia & 2 & 3,476 & $1,093,181$ & 3.3 & 26.4 & 29.0 & 87.5 & 90.1 & 91.0 & 95.5 & 0.0 & 14 & 17 \\
\hline Bosnia and Herzegovina & 2 & 3,782 & 262,062 & 1.0 & 20.8 & 21.2 & 66.4 & 69.8 & 70.1 & 98.8 & 0.7 & 14 & 18 \\
\hline Bosnia and Herzegovina & 3 & 1,806 & 228,314 & 0.3 & 10.6 & 10.7 & 68.8 & 69.4 & 69.7 & 99.2 & 0.5 & 13 & 18 \\
\hline Dominican Republic & 2 & 2,909 & $1,004,082$ & 5.0 & 9.3 & 13.8 & 69.1 & 71.5 & 74.1 & 96.1 & 0.9 & 14 & 17 \\
\hline Georgia & 3 & 4,347 & 293,456 & 1.8 & 31.8 & 33.2 & 75.9 & 77.7 & 80.1 & 98.8 & 0.5 & 14 & 18 \\
\hline Guyana & 2 & 3,207 & 86,386 & 2.6 & 29.5 & 31.4 & 81.6 & 82.9 & 83.8 & 96.4 & 0.3 & 14 & 17 \\
\hline Guyana & 3 & 4,121 & 98,018 & 3.9 & 22.7 & 25.8 & 78.5 & 79.7 & 80.0 & 96.0 & 1.0 & 14 & 18 \\
\hline Iraq & 2 & 19,380 & $3,251,205$ & 1.8 & 13.6 & 14.8 & 46.9 & 53.9 & 55.0 & 74.2 & 6.4 & 14 & 17 \\
\hline Iraq & 3 & 21,089 & $3,624,990$ & 1.6 & 14.6 & 15.7 & 52.6 & 54.8 & 56.1 & 79.4 & 6.2 & 14 & 18 \\
\hline Jamaica & 3 & 2,453 & 307,354 & 1.8 & 8.7 & 10.4 & 85.0 & 85.7 & 85.9 & 99.2 & 0.1 & 14 & 18 \\
\hline Kazakhstan & 3 & 6,947 & $1,257,362$ & 0.2 & 3.7 & 3.9 & 92.1 & 92.8 & 92.9 & 99.4 & 0.3 & 14 & 18 \\
\hline Kyrgyzstan & 3 & 3,776 & 549,445 & 0.2 & 5.3 & 5.5 & 76.8 & 77.1 & 77.6 & 97.7 & 0.6 & 14 & 18 \\
\hline Lao PDR & 2 & 7,636 & 760,832 & 1.9 & 39.9 & 40.7 & 83.6 & 85.2 & 85.6 & 76.5 & 4.2 & 14 & 17 \\
\hline Lao PDR & 3 & 6,705 & 801,700 & 1.5 & 19.0 & 20.1 & 74.5 & 75.5 & 75.8 & 80.5 & 5.5 & 14 & 18 \\
\hline Macedonia & 3 & 2,184 & 141,599 & 0.5 & 11.3 & 11.8 & 55.5 & 56.2 & 56.7 & 95.0 & 2.2 & 14 & 18 \\
\hline Moldova & 2 & 4,048 & 372,421 & 2.6 & 34.1 & 35.1 & 91.9 & 92.4 & 93.7 & 97.9 & 0.6 & 15 & 17 \\
\hline Mongolia & 2 & 4,636 & 318,715 & 1.0 & 22.0 & 22.6 & 95.2 & 95.5 & 95.9 & 86.4 & 0.9 & 17 & 18 \\
\hline Mongolia & 3 & 4,177 & 257,138 & 0.6 & 12.3 & 12.8 & 89.0 & 89.5 & 89.7 & 96.4 & 0.7 & 17 & 18 \\
\hline Montenegro & 3 & 1,011 & 41,595 & 0.8 & 15.3 & 15.6 & 62.0 & 62.2 & 62.4 & 97.9 & 0.9 & 14 & 18 \\
\hline Philippines & 2 & 6,028 & $9,720,255$ & 3.9 & 16.6 & 19.6 & 88.5 & 89.4 & 89.5 & 92.0 & 0.5 & 17 & 17 \\
\hline Serbia & 3 & 2,977 & 612,002 & 0.6 & 6.9 & 7.3 & 64.7 & 65.5 & 65.3 & 99.2 & 0.3 & 14 & 18 \\
\hline Suriname & 3 & 3,047 & 48,033 & 2.6 & 7.8 & 9.7 & 71.1 & 71.8 & 72.2 & 95.8 & 1.1 & 14 & 18 \\
\hline Syria & 3 & 20,463 & $2,410,695$ & 2.1 & 5.6 & 7.2 & 42.1 & 43.3 & 44.4 & 90.4 & 3.7 & 14 & 18 \\
\hline Tajikistan & 2 & 5,055 & 899,610 & 1.3 & 15.3 & 16.3 & 86.4 & 88.8 & 89.1 & 94.0 & 1.1 & 14 & 17 \\
\hline Tajikistan & 3 & 7,239 & 854,172 & 2.6 & 7.4 & 9.8 & 81.1 & 81.8 & 82.5 & 95.6 & 1.2 & 14 & 18 \\
\hline Thailand & 3 & 17,315 & $5,218,705$ & 2.7 & 13.9 & 16.1 & 83.5 & 84.4 & 84.8 & 98.2 & 0.4 & 14 & 18 \\
\hline Trinidad and Tobago & 2 & 2,163 & 124,307 & 1.5 & 3.0 & 4.2 & 63.1 & 64.0 & 63.5 & 98.2 & 0.4 & 14 & 17 \\
\hline Trinidad and Tobago & 3 & 2,007 & 97,494 & 1.1 & 2.1 & 3.2 & 67.0 & 67.3 & 67.5 & 98.8 & 0.6 & 17 & 18 \\
\hline Ukraine & 3 & 1,482 & $2,198,831$ & 1.5 & 17.7 & 18.3 & 86.1 & 87.3 & 87.9 & 99.7 & 0.1 & 14 & 18 \\
\hline Uzbekistan & 2 & 5,426 & $3,311,001$ & 1.3 & 18.2 & 19.4 & 90.7 & 92.7 & 92.7 & 96.0 & 0.5 & 15 & 17 \\
\hline Uzbekistan & 3 & 8,193 & $3,069,926$ & 0.2 & 5.2 & 5.4 & 79.7 & 80.6 & 80.7 & 99.7 & 0.0 & 14 & 18 \\
\hline Venezuela & 2 & 3,083 & $2,828,678$ & 3.3 & 6.9 & 10.1 & 70.7 & 71.6 & 73.2 & 95.0 & 1.6 & 17 & 17 \\
\hline Vietnam & 2 & 6,504 & $9,547,768$ & 1.9 & 31.1 & 32.1 & 64.4 & 71.6 & 72.0 & 90.9 & 1.7 & 15 & 17 \\
\hline Vietnam & 3 & 5,465 & $7,998,166$ & 1.8 & 21.7 & 23.1 & 66.8 & 71.0 & 71.8 & 94.2 & 1.3 & 14 & 18 \\
\hline Yemen & 3 & 5,173 & $2,991,682$ & 2.0 & 18.6 & 19.8 & 62.8 & 68.7 & 69.1 & 75.8 & 6.4 & 14 & 18 \\
\hline
\end{tabular}


Table 3: Analysis of Variance in Key Outcomes

Children 8-14, Pooled Results

\begin{tabular}{llccc}
\hline $\begin{array}{l}\text { Dependent } \\
\text { Variable }\end{array}$ & $\begin{array}{l}\text { Explanatory } \\
\text { Variable }\end{array}$ & All Countries & Africa & Non-Africa \\
\hline Paid Employment & & & \\
& Age & 0.71 & 0.48 & 1.09 \\
& Gender & 0.09 & 0.06 & 0.14 \\
& Household & 63.29 & 67.14 & 57.70 \\
Model & 64.22 & 67.77 & 59.17 \\
Attends School & & & \\
Age & 0.56 & 0.16 & 2.28 \\
Gender & 0.18 & 0.33 & 0.05 \\
Household & 70.36 & 72.77 & 61.06 \\
Model & 71.30 & 73.68 & 63.68 \\
Idle (No School nor Any Type of Work) & & \\
Age & 0.54 & 0.85 & 0.27 \\
Gender & 0.04 & 0.07 & 0.02 \\
Household & 62.16 & 66.48 & 51.20 \\
Model & 63.00 & 67.85 & 51.53 \\
\hline \hline
\end{tabular}

For each dependent variable, we regress the dependent variable on dummies for age, gender, and household. Each cell is the fraction of the total sum of squares in the dependent variable that can be explained by the row variable in the model (the partial sum of squares divided by the total sum of squares). The model row contains the explained sum of squares as a fraction of the total sum of squares. Pooled results are estimated by combining all survey data and weighting by the inverse sampling probability for each individual. Africa restricts the sample to countries listed in Table 2A. Non-Africa restricts sample to countries listed in Table $2 \mathrm{~B}$. 
Table 3A: Analysis of Variance in Paid Employment, Schooling, and Idle Status for Children 8-14, Africa

\begin{tabular}{|c|c|c|c|c|c|c|c|c|c|c|c|c|c|}
\hline \multirow[b]{3}{*}{ Country } & \multirow{3}{*}{$\begin{array}{l}\text { MICS } \\
\text { Round }\end{array}$} & \multicolumn{4}{|c|}{ "Model 1: Paid Employment } & \multirow{2}{*}{\multicolumn{4}{|c|}{ Model 2: Attends School }} & \multicolumn{4}{|c|}{ "Model 3: Idle } \\
\hline & & & & $\mathrm{Hh}$ & & & & & & & & $\mathrm{Hh}$ & \\
\hline & & Age & Gender & Effects & Model & Age & Gender & Effects & Model & Age & Gender & Effects & Model \\
\hline Angola & 2 & 0.73 & 0.04 & 69.29 & 70.03 & 0.43 & 0.13 & 71.69 & 72.39 & 0.74 & 0.04 & 51.06 & 51.94 \\
\hline Burundi & 2 & 0.99 & 0.01 & 62.66 & 63.91 & 2.08 & 0.14 & 64.14 & 68.17 & 0.49 & 0.02 & 59.61 & 60.28 \\
\hline Burundi & 3 & 1.13 & 0.00 & 65.86 & 67.33 & 1.60 & 0.17 & 58.04 & 59.90 & 0.26 & 0.02 & 54.58 & 54.81 \\
\hline Cameroon & 2 & 0.33 & 0.34 & 69.03 & 70.11 & 0.45 & 0.61 & 69.37 & 70.57 & 0.23 & 0.02 & 43.05 & 43.49 \\
\hline Cameroon & 3 & 0.39 & 0.11 & 74.69 & 75.61 & 0.41 & 0.65 & 68.60 & 69.99 & 0.95 & 0.03 & 46.19 & 47.45 \\
\hline Central African Republic & 2 & 0.31 & 0.10 & 71.38 & 71.92 & 0.37 & 1.19 & 67.66 & 69.76 & 0.46 & 0.05 & 46.59 & 47.12 \\
\hline Central African Republic & 3 & 0.24 & 0.04 & 79.18 & 79.51 & 0.35 & 1.36 & 66.31 & 68.48 & 0.11 & 0.03 & 64.70 & 65.49 \\
\hline Chad & 2 & 1.06 & 0.14 & 65.96 & 67.37 & 0.48 & 2.25 & 62.17 & 67.31 & 0.48 & 0.08 & 52.61 & 53.35 \\
\hline Comoros & 2 & 0.21 & 0.36 & 4.18 & 4.75 & 0.83 & 0.09 & 4.43 & 5.34 & 1.60 & 0.49 & 3.66 & 5.86 \\
\hline Cote d'Ivoire & 2 & 0.26 & 0.13 & 4.10 & 4.45 & 0.64 & 2.19 & 4.72 & 7.73 & 0.40 & 0.01 & 4.89 & 5.36 \\
\hline Cote d'Ivoire & 3 & 0.81 & 0.03 & 59.26 & 60.33 & 0.75 & 1.23 & 61.22 & 63.85 & 0.26 & 0.03 & 53.84 & 54.53 \\
\hline DR Congo & 2 & 1.04 & 0.06 & 58.63 & 60.05 & 1.08 & 0.92 & 68.98 & 71.24 & 9.08 & 1.75 & 41.22 & 55.34 \\
\hline Djibouti & 3 & 0.25 & 0.17 & 52.17 & 52.60 & 0.42 & 0.25 & 67.35 & 68.51 & 0.10 & 0.00 & 63.47 & 63.80 \\
\hline Equatorial Guinea & 2 & 0.63 & 0.64 & 61.01 & 62.12 & 0.74 & 0.02 & 56.21 & 57.25 & 0.45 & 0.11 & 48.41 & 49.02 \\
\hline Gambia & 2 & 0.08 & 0.07 & 38.08 & 38.25 & 0.56 & 0.60 & 63.46 & 65.53 & 0.37 & 0.14 & 48.06 & 48.74 \\
\hline Gambia & 3 & 0.21 & 0.06 & 60.75 & 61.17 & 0.25 & 0.05 & 61.76 & 62.57 & 1.43 & 0.18 & 46.99 & 49.14 \\
\hline Ghana & 3 & 0.29 & 0.00 & 82.43 & 83.07 & 0.19 & 0.01 & 72.49 & 72.82 & 0.77 & 0.00 & 45.92 & 47.15 \\
\hline Guinea Bissau & 2 & 0.48 & 0.01 & 58.03 & 58.39 & 0.98 & 0.77 & 60.45 & 63.24 & 0.67 & 0.14 & 42.09 & 43.21 \\
\hline Guinea Bissau & 3 & 0.28 & 0.02 & 82.02 & 82.62 & 1.10 & 0.04 & 64.26 & 66.52 & 0.65 & 0.01 & 54.11 & 54.99 \\
\hline Kenya & 2 & 0.85 & 0.08 & 61.38 & 62.37 & 0.17 & 0.03 & 69.03 & 69.22 & 0.30 & 0.09 & 60.10 & 60.54 \\
\hline Lesotho & 2 & 0.44 & 0.68 & 56.73 & 57.67 & 0.44 & 1.44 & 57.38 & 59.29 & 0.37 & 0.44 & 51.95 & 52.69 \\
\hline Madagascar & 2 & 1.62 & 0.08 & 61.09 & 63.11 & 1.49 & 0.02 & 72.93 & 75.42 & 1.38 & 0.41 & 49.62 & 51.44 \\
\hline Malawi & 3 & 0.68 & 0.00 & 71.60 & 72.26 & 0.34 & -0.02 & 62.76 & 63.23 & 1.02 & 0.07 & 50.71 & 52.00 \\
\hline Mauritania & 3 & 0.57 & 0.04 & 54.15 & 54.95 & 0.67 & 0.03 & 66.51 & 67.48 & 0.93 & 0.08 & 55.80 & 57.06 \\
\hline Niger & 2 & 0.22 & 0.04 & 70.92 & 71.46 & 0.41 & 1.52 & 68.48 & 71.97 & 0.41 & 0.05 & 47.79 & 48.24 \\
\hline Nigeria & 3 & 0.31 & 0.14 & 73.02 & 73.63 & 0.04 & 0.10 & 86.81 & 87.66 & 0.28 & 0.00 & 83.68 & 84.29 \\
\hline Rwanda & 2 & 1.27 & 0.00 & 62.01 & 63.26 & 2.94 & 0.06 & 56.02 & 59.44 & 0.77 & 0.00 & 45.24 & 45.98 \\
\hline Sao Tome and Principe & 2 & 0.77 & 0.15 & 61.86 & 63.10 & 3.52 & 0.11 & 59.89 & 65.37 & 0.47 & 0.06 & 54.44 & 55.19 \\
\hline Senegal & 2 & 0.38 & 0.01 & 54.80 & 55.28 & 1.11 & 0.56 & 63.83 & 66.50 & 0.22 & 0.05 & 45.57 & 45.94 \\
\hline Sierra Leone & 2 & 0.16 & 0.01 & 68.99 & 69.92 & 0.13 & 0.36 & 74.69 & 75.21 & 0.28 & 0.00 & 67.58 & 68.46 \\
\hline Sierra Leone & 3 & 0.02 & 0.01 & 93.96 & 94.03 & 0.61 & 0.11 & 64.75 & 66.14 & 0.24 & 0.02 & 59.29 & 59.81 \\
\hline Somalia & 3 & 0.45 & 0.00 & 54.02 & 54.90 & 0.37 & 1.78 & 70.64 & 74.17 & 1.69 & 0.00 & 57.34 & 59.20 \\
\hline Sudan, Northern & 2 & 1.10 & 0.28 & 61.66 & 63.36 & 0.34 & 0.08 & 80.46 & 81.91 & 1.52 & 0.05 & 66.55 & 69.18 \\
\hline Sudan, Southern & 2 & 0.67 & 0.10 & 63.94 & 66.13 & 0.67 & 0.28 & 74.54 & 75.73 & 1.28 & 0.01 & 59.78 & 61.95 \\
\hline
\end{tabular}


Table 3A: Analysis of Variance in Paid Employment, Schooling, and Idle Status for Children 8-14, Africa

\begin{tabular}{|c|c|c|c|c|c|c|c|c|c|c|c|c|c|}
\hline \multirow[b]{2}{*}{ Country } & \multirow[b]{2}{*}{$\begin{array}{l}\text { MICS } \\
\text { Round }\end{array}$} & \multicolumn{4}{|c|}{ Model 1: Paid Employment } & \multicolumn{4}{|c|}{$\begin{array}{c}\text { Model 2: Attends School } \\
\mathrm{Hh}\end{array}$} & \multicolumn{4}{|c|}{ Model 3: Idle } \\
\hline & & Age & Gender & $\begin{array}{c}\text { Hh } \\
\text { Effects }\end{array}$ & Model & Age & Gender & $\begin{array}{c}\text { Hh } \\
\text { Effects }\end{array}$ & Model & Age & Gender & $\begin{array}{c}\text { Hh } \\
\text { Effects }\end{array}$ & Model \\
\hline Swaziland & 2 & 0.37 & 0.02 & 51.37 & 51.75 & 0.35 & 0.10 & 61.17 & 61.58 & 0.35 & 0.03 & 52.78 & 53.17 \\
\hline Togo & 2 & 0.77 & 0.01 & 77.08 & 78.18 & 0.48 & 1.37 & 59.45 & 61.91 & 0.83 & 0.00 & 45.96 & 46.77 \\
\hline Togo & 3 & 0.26 & 0.04 & 76.64 & 77.69 & 0.55 & 0.75 & 63.37 & 65.36 & 0.46 & 0.04 & 55.39 & 55.98 \\
\hline
\end{tabular}

Each model is a regression of the dependent variable (listed as "model") on dummies for age, gender, and household. Each cell is the fraction of the total sum of squares in the dependent variable that can be explained by the column variables in the model (the partial sum of squares divided by the total sum of squares). The model column contains the explained sum of squares as a fraction of the total sum of squares. 
Table 3B: Analysis of Variance in Paid Employment, Schooling, and Idle Status for Children 8-14, Non-Africa

\begin{tabular}{|c|c|c|c|c|c|c|c|c|c|c|c|c|c|}
\hline \multirow[b]{2}{*}{ Country } & \multirow{2}{*}{$\begin{array}{l}\text { MICS } \\
\text { Round }\end{array}$} & \multicolumn{4}{|c|}{ Model 1: Paid Employment } & \multicolumn{4}{|c|}{$\begin{array}{c}\text { Model 2: Attends School } \\
\text { Hh }\end{array}$} & \multicolumn{4}{|c|}{$\begin{aligned} & \text { Model 3: } \text { Idle } \\
& \text { Hh }\end{aligned}$} \\
\hline & & Age & Gender & Effects & Model & Age & Gender & Effects & Model & Age & Gender & Effects & Model \\
\hline Albania & 2 & 0.23 & 0.01 & 78.61 & 78.87 & 0.03 & 0.00 & 97.05 & 97.34 & 1.82 & 0.12 & 72.68 & 76.47 \\
\hline Albania & 3 & 1.38 & 0.63 & 48.45 & 49.50 & 9.71 & 0.07 & 41.44 & 55.28 & 1.39 & 0.00 & 41.01 & 42.51 \\
\hline Azerbaijan & 2 & 0.03 & 0.00 & 79.38 & 79.51 & 0.59 & 0.12 & 61.95 & 62.73 & 0.50 & 0.00 & 51.82 & 52.52 \\
\hline Bangladesh & 3 & 1.91 & 0.61 & 54.16 & 57.28 & 6.17 & 0.50 & 54.39 & 62.35 & 0.19 & 0.54 & 48.58 & 49.65 \\
\hline Belarus & 3 & 1.07 & 0.27 & 79.54 & 80.55 & & & & & & & & \\
\hline Bosnia and Herzegovina & 2 & 0.15 & 0.15 & 74.67 & 75.34 & 0.63 & 0.02 & 62.04 & 63.08 & 0.52 & 0.02 & 57.87 & 58.69 \\
\hline Bosnia and Herzegovina & 3 & 0.25 & 0.01 & 61.18 & 61.33 & 0.19 & 0.52 & 59.84 & 60.36 & 0.17 & 0.60 & 52.16 & 52.88 \\
\hline Dominican Republic & 2 & 0.80 & 0.60 & 49.50 & 52.01 & 0.22 & 0.00 & 62.55 & 62.97 & 0.84 & 0.19 & 42.65 & 43.51 \\
\hline Georgia & 3 & 0.08 & 0.03 & 84.86 & 85.18 & 0.22 & 0.01 & 67.39 & 68.14 & 0.09 & 0.01 & 64.05 & 64.49 \\
\hline Guyana & 2 & 0.88 & 0.34 & 67.06 & 67.59 & 1.78 & 0.02 & 44.25 & 45.94 & 0.23 & 0.00 & 44.67 & 45.29 \\
\hline Guyana & 3 & 0.17 & 0.12 & 77.85 & 78.45 & 1.83 & 0.06 & 59.48 & 62.00 & 0.09 & 0.05 & 59.83 & 60.21 \\
\hline Iraq & 2 & 1.34 & 0.96 & 45.28 & 48.39 & 4.25 & 2.62 & 56.50 & 65.88 & 0.58 & 0.05 & 51.55 & 52.25 \\
\hline Iraq & 3 & 0.65 & 0.52 & 53.45 & 55.37 & 5.03 & 2.53 & 54.30 & 65.21 & 0.20 & 0.23 & 51.87 & 52.64 \\
\hline Jamaica & 3 & 0.27 & 0.24 & 73.03 & 74.09 & 0.91 & 0.01 & 43.52 & 44.78 & 0.56 & 0.05 & 39.79 & 40.11 \\
\hline Kazakhstan & 3 & 0.14 & 0.06 & 59.14 & 59.37 & 0.11 & 0.06 & 49.29 & 49.44 & 0.25 & 0.01 & 48.98 & 49.18 \\
\hline Kyrgyzstan & 3 & 0.14 & 0.02 & 69.64 & 69.75 & 0.91 & 0.22 & 75.53 & 76.43 & 0.74 & 0.00 & 40.50 & 41.28 \\
\hline Lao PDR & 2 & 0.53 & 0.00 & 68.69 & 69.13 & 1.37 & 0.87 & 62.83 & 65.65 & 3.23 & 0.00 & 48.23 & 52.52 \\
\hline Lao PDR & 3 & 0.84 & 0.03 & 58.63 & 59.67 & 2.57 & 0.80 & 57.85 & 62.56 & 3.10 & 0.01 & 48.13 & 51.56 \\
\hline Macedonia & 3 & 0.03 & 0.01 & 81.69 & 81.85 & 1.30 & 0.15 & 73.50 & 74.47 & 0.20 & 0.01 & 70.72 & 71.97 \\
\hline Moldova & 2 & 0.29 & 0.08 & 77.54 & 78.24 & 0.49 & 0.28 & 60.75 & 61.90 & 0.50 & 0.00 & 56.31 & 56.92 \\
\hline Mongolia & 2 & 0.09 & 0.00 & 84.75 & 85.11 & 5.66 & 0.64 & 50.68 & 60.02 & 0.80 & 0.08 & 40.59 & 41.31 \\
\hline Mongolia & 3 & 0.08 & 0.08 & 65.45 & 65.72 & 0.23 & 0.23 & 54.90 & 55.64 & 0.57 & 0.05 & 44.16 & 44.46 \\
\hline Montenegro & 3 & & & & & 0.23 & 0.02 & 80.19 & 80.59 & 0.11 & 0.01 & 84.60 & 85.20 \\
\hline Philippines & 2 & 1.36 & 0.10 & 63.28 & 64.77 & 1.85 & 0.09 & 60.07 & 62.57 & 0.54 & 0.01 & 44.37 & 44.99 \\
\hline Serbia & 3 & 0.26 & 0.02 & 73.55 & 73.81 & 0.08 & 0.01 & 74.18 & 74.38 & 0.02 & 0.03 & 61.16 & 61.26 \\
\hline Suriname & 3 & 0.36 & 0.22 & 79.28 & 80.24 & 0.17 & 0.04 & 70.63 & 71.15 & 0.22 & 0.03 & 59.22 & 59.53 \\
\hline Syria & 3 & 2.16 & 0.52 & 47.30 & 51.01 & 8.09 & 0.05 & 44.39 & 55.71 & 1.50 & 0.01 & 43.94 & 46.14 \\
\hline Tajikistan & 2 & 0.29 & 0.00 & 69.14 & 69.62 & 0.70 & 0.22 & 62.66 & 63.95 & 0.64 & 0.08 & 40.60 & 41.57 \\
\hline Tajikistan & 3 & 0.76 & 0.00 & 67.94 & 68.89 & 1.48 & 0.58 & 52.57 & 55.30 & 0.90 & 0.04 & 43.59 & 44.69 \\
\hline
\end{tabular}


Table 3B: Analysis of Variance in Paid Employment, Schooling, and Idle Status for Children 8-14, Non-Africa

\begin{tabular}{|c|c|c|c|c|c|c|c|c|c|c|c|c|c|}
\hline \multirow[b]{2}{*}{ Country } & \multirow{2}{*}{$\begin{array}{l}\text { MICS } \\
\text { Round }\end{array}$} & \multicolumn{4}{|c|}{ Model 1: Paid Employment } & \multicolumn{4}{|c|}{$\begin{array}{c}\text { Model 2: Attends School } \\
\mathrm{Hh}\end{array}$} & \multicolumn{4}{|c|}{$\begin{aligned} \text { Model 3: Idle } \\
\text { Hh }\end{aligned}$} \\
\hline & & Age & Gender & Effects & Model & Age & Gender & Effects & Model & Age & Gender & Effects & Model \\
\hline Thailand & 3 & 0.85 & 0.00 & 65.48 & 66.54 & 1.75 & 0.02 & 59.48 & 61.64 & 0.22 & 0.01 & 50.06 & 50.27 \\
\hline Trinidad and Tobago & 2 & 0.28 & 0.20 & 57.85 & 59.14 & 2.25 & 0.00 & 35.92 & 39.00 & 0.63 & 0.15 & 42.51 & 43.61 \\
\hline Trinidad and Tobago & 3 & 1.01 & 0.01 & 65.99 & 68.27 & 0.49 & 0.08 & 57.01 & 58.02 & 0.27 & 0.03 & 44.74 & 45.23 \\
\hline Ukraine & 3 & 1.07 & 0.21 & 44.57 & 45.68 & & & & & & & & \\
\hline Uzbekistan & 2 & 0.25 & 0.04 & 78.07 & 78.33 & 0.16 & 0.00 & 80.81 & 81.14 & 0.42 & 0.01 & 38.77 & 39.09 \\
\hline Uzbekistan & 3 & 0.04 & 0.05 & 65.32 & 65.39 & 0.11 & 0.00 & 51.45 & 51.74 & 0.03 & 0.00 & 69.27 & 69.39 \\
\hline Venezuela & 2 & 1.24 & 0.24 & 54.11 & 57.78 & 0.38 & 0.70 & 63.46 & 64.19 & 0.90 & 0.34 & 57.46 & 58.13 \\
\hline Vietnam & 2 & 2.02 & 0.00 & 47.88 & 50.25 & 3.57 & 0.15 & 57.23 & 62.32 & 0.52 & 0.00 & 50.71 & 51.33 \\
\hline Vietnam & 3 & 1.36 & 0.11 & 57.05 & 59.44 & 3.29 & 0.05 & 52.39 & 55.93 & 0.13 & 0.03 & 51.89 & 52.19 \\
\hline Yemen & 3 & 1.00 & 0.29 & 57.60 & 59.21 & 1.61 & 2.03 & 60.80 & 66.19 & 2.53 & 0.00 & 48.93 & 51.54 \\
\hline
\end{tabular}

Each model is a regression of the dependent variable (listed as "model") on dummies for age, gender, and household. Each cell is the fraction of the total sum of squares in the dependent variable that can be explained by the column variables in the model (the partial sum of squares divided by the total sum of squares). The model column contains the explained sum of squares as a fraction of the total sum of squares. 
Table 4: Changes in Time Allocation at the Age of Relaxation of Regulation, Pooled Findings

\begin{tabular}{|c|c|c|c|c|c|c|c|c|c|}
\hline Regi Regulation & $\begin{array}{c}\text { Paid Em } \\
\text { Base }\end{array}$ & $\begin{array}{c}\text { ployment } \\
\text { Change }\end{array}$ & $\begin{array}{l}\text { Unpaid } \\
\text { Economic } \\
\text { Activity }\end{array}$ & $\begin{array}{l}\text { Economic } \\
\text { Activity }\end{array}$ & $\begin{array}{l}\text { Unpaid } \\
\text { Hh. } \\
\text { Services }\end{array}$ & $\begin{array}{c}\text { Hh. Based } \\
\text { EA \& } \\
\text { Services }\end{array}$ & $\begin{array}{c}\text { Any } \\
\text { Work }\end{array}$ & $\begin{array}{l}\text { Attend } \\
\text { School }\end{array}$ & Idle \\
\hline \multicolumn{10}{|l|}{ All Countries } \\
\hline Light Work & $\begin{array}{c}0.037 \\
(0.003)\end{array}$ & $\begin{array}{l}-0.001 \\
(0.006)\end{array}$ & $\begin{array}{c}0.069 \\
(0.159)\end{array}$ & $\begin{array}{c}0.070 \\
(0.160)\end{array}$ & $\begin{array}{l}-0.060 \\
(0.081)\end{array}$ & $\begin{array}{l}-0.053 \\
(0.090)\end{array}$ & $\begin{array}{l}-0.052 \\
(0.092)\end{array}$ & $\begin{array}{l}-0.051 \\
(0.039)\end{array}$ & $\begin{array}{c}0.027 \\
(0.033)\end{array}$ \\
\hline Minimum Non-Hazardous & $\begin{array}{c}0.061 \\
(0.003)\end{array}$ & $\begin{array}{c}0.007 \\
(0.004)\end{array}$ & $\begin{array}{l}-0.013 \\
(0.040)\end{array}$ & $\begin{array}{c}0.001 \\
(0.041)\end{array}$ & $\begin{array}{l}-0.016 \\
(0.032)\end{array}$ & $\begin{array}{l}-0.019 \\
(0.034)\end{array}$ & $\begin{array}{l}-0.012 \\
(0.032)\end{array}$ & $\begin{array}{l}-0.001 \\
(0.021)\end{array}$ & $\begin{array}{l}-0.007 \\
(0.011)\end{array}$ \\
\hline Compulsory Schooling & $\begin{array}{c}0.056 \\
(0.003)\end{array}$ & $\begin{array}{c}0.003 \\
(0.004)\end{array}$ & $\begin{array}{c}0.017 \\
(0.028)\end{array}$ & $\begin{array}{c}0.024 \\
(0.030)\end{array}$ & $\begin{array}{c}0.010 \\
(0.076)\end{array}$ & $\begin{array}{c}0.010 \\
(0.075)\end{array}$ & $\begin{array}{c}0.015 \\
(0.072)\end{array}$ & $\begin{array}{l}-0.105 * \\
(0.046)\end{array}$ & $\begin{array}{c}0.027 \\
(0.023)\end{array}$ \\
\hline \multicolumn{10}{|l|}{ Africa } \\
\hline Light Work & $\begin{array}{c}0.050 \\
(0.005)\end{array}$ & $\begin{array}{c}0.000 \\
(0.009)\end{array}$ & $\begin{array}{c}0.042 \\
(0.199)\end{array}$ & $\begin{array}{c}0.043 \\
(0.202)\end{array}$ & $\begin{array}{l}-0.055 \\
(0.162)\end{array}$ & $\begin{array}{l}-0.048 \\
(0.177)\end{array}$ & $\begin{array}{l}-0.046 \\
(0.179)\end{array}$ & $\begin{array}{l}-0.040 \\
(0.100)\end{array}$ & $\begin{array}{c}0.026 \\
(0.097)\end{array}$ \\
\hline Minimum Non-Hazardous & $\begin{array}{c}0.065 \\
(0.005)\end{array}$ & $\begin{array}{c}0.007 \\
(0.006)\end{array}$ & $\begin{array}{l}-0.087 \\
(0.074)\end{array}$ & $\begin{array}{l}-0.086 \\
(0.074)\end{array}$ & $\begin{array}{c}0.065 \\
(0.051)\end{array}$ & $\begin{array}{c}0.069 \\
(0.059)\end{array}$ & $\begin{array}{c}0.070 \\
(0.062)\end{array}$ & $\begin{array}{l}-0.020 \\
(0.045)\end{array}$ & $\begin{array}{c}0.014 \\
(0.026)\end{array}$ \\
\hline Compulsory Schooling & $\begin{array}{c}0.049 \\
(0.008)\end{array}$ & $\begin{array}{c}0.010 \\
(0.015)\end{array}$ & $\begin{array}{c}0.008 \\
(0.099)\end{array}$ & $\begin{array}{c}0.012 \\
(0.105)\end{array}$ & $\begin{array}{c}0.016 \\
(0.107)\end{array}$ & $\begin{array}{c}0.022 \\
(0.113)\end{array}$ & $\begin{array}{c}0.010 \\
(0.115)\end{array}$ & $\begin{array}{l}-0.006 \\
(0.025)\end{array}$ & $\begin{array}{l}-0.008 \\
(0.051)\end{array}$ \\
\hline
\end{tabular}

$\overline{\text { Change in column variable at age of relaxation of regulation listed in row. All countries in region pooled. Age cell level regressions. Each cell }}$ weighted by population. 


\begin{tabular}{|c|c|c|c|c|c|c|c|c|c|c|c|c|c|c|c|c|c|c|}
\hline Country & $\begin{array}{l}\text { MICS } \\
\text { Rnd }\end{array}$ & \multicolumn{2}{|c|}{$\begin{array}{c}\text { Paid } \\
\text { Employment }\end{array}$} & \multicolumn{2}{|r|}{$\begin{array}{l}\text { Unpaid } \\
\text { Economic } \\
\text { Activity }\end{array}$} & \multicolumn{3}{|c|}{$\begin{array}{c}\text { Economic } \\
\text { Activity } \\
\end{array}$} & \multicolumn{2}{|l|}{$\begin{array}{c}\text { Unpaid } \\
\text { Hh. } \\
\text { Services }\end{array}$} & \multicolumn{2}{|l|}{$\begin{array}{c}\text { Hh. Based } \\
\text { EA \& } \\
\text { Services } \\
\end{array}$} & \multicolumn{2}{|l|}{$\begin{array}{l}\text { Any } \\
\text { Work }\end{array}$} & \multicolumn{2}{|l|}{$\begin{array}{l}\text { Attend } \\
\text { School } \\
\end{array}$} & \multicolumn{2}{|l|}{ Idle } \\
\hline Africa & & & & & & & & & & & & & & & & & & \\
\hline Burundi & 2 & $\begin{array}{c}0.054 \\
(0.009)\end{array}$ & $\begin{array}{l}-0.014 \\
(0.011)\end{array}$ & & $\begin{array}{c}0.006 \\
(0.003)\end{array}$ & & $\begin{array}{c}0.005 \\
(0.012)\end{array}$ & & $\begin{array}{c}0.002 \\
(0.017)\end{array}$ & & $\begin{array}{l}0.008 \\
(0.024)\end{array}$ & & $\begin{array}{l}-0.001 \\
(0.015)\end{array}$ & & $\begin{array}{l}-0.017 \\
(0.016)\end{array}$ & & $\begin{array}{c}-0.022 \\
(0.015)\end{array}$ & \\
\hline Burundi & 2 & $\begin{array}{c}0.050 \\
(0.002)\end{array}$ & $\begin{array}{l}-0.007 \\
(0.002)\end{array}$ & & $\begin{array}{c}0.012 \\
(0.006)\end{array}$ & & $\begin{array}{l}-0.005 \\
(0.007)\end{array}$ & & $\begin{array}{c}0.018 \\
(0.002)\end{array}$ & $*$ & $\begin{array}{c}0.022 \\
(0.009)\end{array}$ & & $\begin{array}{c}0.030 \\
(0.004)\end{array}$ & * & $\begin{array}{l}-0.074 \\
(0.015)\end{array}$ & $* *$ & $\begin{array}{c}0.004 \\
(0.004)\end{array}$ & \\
\hline Central African Republic & 2 & $\begin{array}{c}0.033 \\
(0.006)\end{array}$ & $\begin{array}{c}0.017 \\
(0.006)\end{array}$ & & $\begin{array}{c}0.045 \\
(0.025)\end{array}$ & & $\begin{array}{c}0.047 \\
(0.028)\end{array}$ & & $\begin{array}{l}-0.012 \\
(0.014)\end{array}$ & & $\begin{array}{l}-0.012 \\
(0.016)\end{array}$ & & $\begin{array}{c}0.017 \\
(0.018)\end{array}$ & & $\begin{array}{l}-0.068 \\
(0.027)\end{array}$ & & $\begin{array}{c}0.011 \\
(0.009)\end{array}$ & \\
\hline Central African Republic & 3 & $\begin{array}{c}0.056 \\
(0.004)\end{array}$ & $\begin{array}{l}-0.012 \\
(0.004)\end{array}$ & & $\begin{array}{l}-0.062 \\
(0.004)\end{array}$ & $* *$ & $\begin{array}{l}-0.069 \\
(0.018)\end{array}$ & & $\begin{array}{l}0.065 \\
(0.019)\end{array}$ & & $\begin{array}{c}0.037 \\
(0.011)\end{array}$ & & $\begin{array}{c}0.014 \\
(0.007)\end{array}$ & & $\begin{array}{l}-0.084 \\
(0.044)\end{array}$ & & $\begin{array}{c}0.015 \\
(0.013)\end{array}$ & \\
\hline Chad & 2 & $\begin{array}{c}0.137 \\
(0.011)\end{array}$ & $\begin{array}{l}-0.077 \\
(0.012)\end{array}$ & * & $\begin{array}{l}-0.040 \\
(0.010)\end{array}$ & * & $\begin{array}{l}-0.043 \\
(0.001)\end{array}$ & $* *$ & $\begin{array}{l}-0.102 \\
(0.035)\end{array}$ & & $\begin{array}{l}-0.025 \\
(0.009)\end{array}$ & & $\begin{array}{l}-0.021 \\
(0.012)\end{array}$ & & $\begin{array}{l}-0.081 \\
(0.048)\end{array}$ & & $\begin{array}{c}0.013 \\
(0.003)\end{array}$ & $*$ \\
\hline D.R. Congo & 2 & $\begin{array}{c}0.066 \\
(0.007)\end{array}$ & $\begin{array}{l}-0.014 \\
(0.010)\end{array}$ & & $\begin{array}{l}-0.161 \\
(0.118)\end{array}$ & & $\begin{array}{l}-0.171 \\
(0.126)\end{array}$ & & $\begin{array}{l}-0.231 \\
(0.183)\end{array}$ & & $\begin{array}{l}-0.230 \\
(0.195)\end{array}$ & & $\begin{array}{l}-0.232 \\
(0.199)\end{array}$ & & $\begin{array}{c}0.032 \\
(0.024)\end{array}$ & & $\begin{array}{l}-0.041 \\
(0.068)\end{array}$ & \\
\hline Equatorial Guinea & 2 & $\begin{array}{c}0.051 \\
(0.011)\end{array}$ & $\begin{array}{l}-0.006 \\
(0.015)\end{array}$ & & $\begin{array}{c}0.034 \\
(0.053)\end{array}$ & & $\begin{array}{c}0.031 \\
(0.040)\end{array}$ & & $\begin{array}{l}-0.003 \\
(0.023)\end{array}$ & & $\begin{array}{l}-0.003 \\
(0.018)\end{array}$ & & $\begin{array}{c}0.029 \\
(0.016)\end{array}$ & & $\begin{array}{l}-0.017 \\
(0.026)\end{array}$ & & $\begin{array}{l}-0.004 \\
(0.007)\end{array}$ & \\
\hline Gambia & 3 & & & & & & & & & & & & & & $\begin{array}{c}0.032 \\
(0.040)\end{array}$ & & & \\
\hline Ghana & 3 & $\begin{array}{c}0.083 \\
(0.011)\end{array}$ & $\begin{array}{l}-0.025 \\
(0.015)\end{array}$ & & $\begin{array}{c}0.009 \\
(0.024)\end{array}$ & & $\begin{array}{l}-0.045 \\
(0.026)\end{array}$ & & $\begin{array}{c}-0.064 \\
(0.062)\end{array}$ & & $\begin{array}{l}-0.050 \\
(0.028)\end{array}$ & & $\begin{array}{c}0.023 \\
(0.017)\end{array}$ & & $\begin{array}{l}-0.053 \\
(0.020)\end{array}$ & * & $\begin{array}{c}0.007 \\
(0.005)\end{array}$ & \\
\hline Kenya & 2 & $\begin{array}{c}0.035 \\
(0.007)\end{array}$ & $\begin{array}{c}0.017 \\
(0.010)\end{array}$ & & $\begin{array}{c}0.013 \\
(0.002)\end{array}$ & & $\begin{array}{c}0.016 \\
(0.008)\end{array}$ & & $\begin{array}{c}0.009 \\
(0.033)\end{array}$ & & $\begin{array}{c}0.009 \\
(0.033)\end{array}$ & & $\begin{array}{c}0.011 \\
(0.037)\end{array}$ & & $\begin{array}{l}-0.015 \\
(0.008)\end{array}$ & & $\begin{array}{c}0.012 \\
(0.010)\end{array}$ & \\
\hline Lesotho & 2 & $\begin{array}{c}0.021 \\
(0.004)\end{array}$ & $\begin{array}{c}-0.009 \\
(0.006)\end{array}$ & & $\begin{array}{l}-0.089 \\
(0.044)\end{array}$ & & $\begin{array}{l}-0.029 \\
(0.019)\end{array}$ & & $\begin{array}{l}-0.073 \\
(0.011)\end{array}$ & $* *$ & $\begin{array}{l}-0.076 \\
(0.005)\end{array}$ & $* *$ & $\begin{array}{l}-0.081 \\
(0.005)\end{array}$ & $* *$ & $\begin{array}{l}-0.106 \\
(0.019)\end{array}$ & & $\begin{array}{c}0.025 \\
(0.006)\end{array}$ & ** \\
\hline Mauritania & 3 & $\begin{array}{c}0.012 \\
(0.001)\end{array}$ & $\begin{array}{c}0.019 \\
(0.002)\end{array}$ & $* *$ & $\begin{array}{c}0.005 \\
(0.037)\end{array}$ & & $\begin{array}{c}0.018 \\
(0.035)\end{array}$ & & $\begin{array}{l}-0.009 \\
(0.010)\end{array}$ & & $\begin{array}{c}0.023 \\
(0.002)\end{array}$ & $*$ & $\begin{array}{c}0.041 \\
(0.002)\end{array}$ & $* *$ & $\begin{array}{l}-0.106 \\
(0.042)\end{array}$ & & $\begin{array}{l}-0.013 \\
(0.002)\end{array}$ & * \\
\hline Sierra Leone & 2 & $\begin{array}{c}0.052 \\
(0.009)\end{array}$ & $\begin{array}{l}-0.020 \\
(0.010)\end{array}$ & & $\begin{array}{c}0.012 \\
(0.037)\end{array}$ & & $\begin{array}{c}0.020 \\
(0.038)\end{array}$ & & $\begin{array}{c}0.077 \\
(0.018)\end{array}$ & & $\begin{array}{c}0.032 \\
(0.009)\end{array}$ & & $\begin{array}{c}0.035 \\
(0.004)\end{array}$ & $*$ & $\begin{array}{l}-0.013 \\
(0.065)\end{array}$ & & $\begin{array}{l}-0.006 \\
(0.016)\end{array}$ & \\
\hline Sierra Leone & 3 & $\begin{array}{c}0.025 \\
(0.011)\end{array}$ & $\begin{array}{c}0.019 \\
(0.012)\end{array}$ & & $\begin{array}{l}-0.026 \\
(0.047)\end{array}$ & & $\begin{array}{l}-0.024 \\
(0.040)\end{array}$ & & $\begin{array}{l}-0.009 \\
(0.005)\end{array}$ & & $\begin{array}{l}-0.012 \\
(0.006)\end{array}$ & & $\begin{array}{l}-0.011 \\
(0.001)\end{array}$ & $* *$ & $\begin{array}{l}-0.041 \\
(0.047)\end{array}$ & & $\begin{array}{c}0.005 \\
(0.002)\end{array}$ & \\
\hline Non-Af & & & & & & & & & & & & & & & & & & \\
\hline Albania & 2 & $\begin{array}{c}0.025 \\
(0.007)\end{array}$ & $\begin{array}{l}-0.005 \\
(0.008)\end{array}$ & & $\begin{array}{c}0.109 \\
(0.059)\end{array}$ & & $\begin{array}{c}0.098 \\
(0.052)\end{array}$ & & $\begin{array}{c}0.019 \\
(0.055)\end{array}$ & & $\begin{array}{c}0.034 \\
(0.024)\end{array}$ & & $\begin{array}{c}0.026 \\
(0.021)\end{array}$ & & $\begin{array}{c}0.118 \\
(0.040)\end{array}$ & $*$ & $\begin{array}{l}-0.024 \\
(0.032)\end{array}$ & \\
\hline Albania & 3 & 0.010 & -0.001 & & -0.060 & * & -0.061 & $*$ & -0.139 & $*$ & -0.153 & $* *$ & -0.149 & ** & -0.149 & $* *$ & 0.031 & $* *$ \\
\hline
\end{tabular}


Table 5: Changes in Time Allocation at the Age of Relaxation of Minimum Age Laws (Light Work)

\begin{tabular}{|c|c|c|c|c|c|c|c|c|c|c|c|c|c|c|c|c|c|c|}
\hline Country & $\begin{array}{c}\text { MICS } \\
\text { Rnd }\end{array}$ & $\begin{array}{l}\mathrm{Pa} \\
\text { Emplo } \\
\text { Base } \\
\end{array}$ & $\begin{array}{l}\text { id } \\
\text { yment } \\
\text { Change }\end{array}$ & & $\begin{array}{c}\text { Unpaid } \\
\text { Economic } \\
\text { Activity }\end{array}$ & & $\begin{array}{c}\text { Economic } \\
\text { Activity }\end{array}$ & & $\begin{array}{c}\text { Unpaid } \\
\text { Hh. } \\
\text { Services }\end{array}$ & & $\begin{array}{c}\text { Hh. Based } \\
\text { EA \& } \\
\text { Services }\end{array}$ & & $\begin{array}{l}\text { Any } \\
\text { Work }\end{array}$ & & $\begin{array}{l}\text { Attend } \\
\text { School } \\
\end{array}$ & & Idle & \\
\hline & & $(0.005)$ & (0.007) & & $(0.025)$ & & $(0.026)$ & & $(0.053)$ & & $(0.044)$ & & $(0.043)$ & & $(0.012)$ & & $(0.006)$ & \\
\hline Kazakhstan & 3 & $\begin{array}{c}0.009 \\
(0.001)\end{array}$ & $\begin{array}{l}-0.005 \\
(0.002)\end{array}$ & $*$ & $\begin{array}{c}0.002 \\
(0.005)\end{array}$ & & $\begin{array}{l}-0.013 \\
(0.005)\end{array}$ & $*$ & $\begin{array}{c}0.021 \\
(0.001)\end{array}$ & $* *$ & $\begin{array}{c}0.021 \\
(0.001)\end{array}$ & $* *$ & $\begin{array}{c}0.017 \\
(0.002)\end{array}$ & ** & $\begin{array}{l}-0.003 \\
(0.003)\end{array}$ & & $\begin{array}{c}0.002 \\
(0.002)\end{array}$ & \\
\hline Kyrgyzstan & 3 & $\begin{array}{c}0.003 \\
(0.001)\end{array}$ & $\begin{array}{c}0.002 \\
(0.002)\end{array}$ & & $\begin{array}{c}0.011 \\
(0.019)\end{array}$ & & $\begin{array}{c}0.011 \\
(0.021)\end{array}$ & & $\begin{array}{c}0.022 \\
(0.065)\end{array}$ & & $\begin{array}{c}0.027 \\
(0.068)\end{array}$ & & $\begin{array}{c}0.033 \\
(0.072)\end{array}$ & & $\begin{array}{c}0.015 \\
(0.015)\end{array}$ & & $\begin{array}{l}-0.017 \\
(0.007)\end{array}$ & * \\
\hline Moldova & 2 & $\begin{array}{c}0.041 \\
(0.007)\end{array}$ & $\begin{array}{c}0.000 \\
(0.010)\end{array}$ & & $\begin{array}{c}0.043 \\
(0.017)\end{array}$ & $*$ & $\begin{array}{c}0.074 \\
(0.029)\end{array}$ & & $\begin{array}{l}-0.059 \\
(0.033)\end{array}$ & & $\begin{array}{l}-0.042 \\
(0.034)\end{array}$ & & $\begin{array}{l}-0.025 \\
(0.017)\end{array}$ & & $\begin{array}{l}-0.017 \\
(0.013)\end{array}$ & & $\begin{array}{c}0.002 \\
(0.007)\end{array}$ & \\
\hline Suriname & 3 & $\begin{array}{c}0.035 \\
(0.006)\end{array}$ & $\begin{array}{l}-0.012 \\
(0.008)\end{array}$ & & $\begin{array}{l}-0.029 \\
(0.009)\end{array}$ & & $\begin{array}{l}-0.017 \\
(0.005)\end{array}$ & $*$ & $\begin{array}{l}-0.034 \\
(0.032)\end{array}$ & & $\begin{array}{l}-0.035 \\
(0.028)\end{array}$ & & $\begin{array}{l}-0.039 \\
(0.030)\end{array}$ & & $\begin{array}{c}0.021 \\
(0.018)\end{array}$ & & $\begin{array}{l}-0.010 \\
(0.003)\end{array}$ & $*$ \\
\hline Trinidad and Tobago & 2 & $\begin{array}{c}0.061 \\
(0.003)\end{array}$ & $\begin{array}{l}-0.040 \\
(0.003)\end{array}$ & ** & $\begin{array}{l}-0.022 \\
(0.006)\end{array}$ & $*$ & $\begin{array}{l}-0.031 \\
(0.010)\end{array}$ & $*$ & $\begin{array}{l}-0.071 \\
(0.118)\end{array}$ & & $\begin{array}{l}-0.073 \\
(0.109)\end{array}$ & & $\begin{array}{l}-0.082 \\
(0.109)\end{array}$ & & $\begin{array}{l}-0.007 \\
(0.004)\end{array}$ & & & \\
\hline Trinidad and Tobago & 3 & $\begin{array}{c}0.012 \\
(0.001)\end{array}$ & $\begin{array}{c}0.024 \\
(0.002)\end{array}$ & $* *$ & $\begin{array}{c}0.002 \\
(0.012)\end{array}$ & & $\begin{array}{c}0.028 \\
(0.012)\end{array}$ & $*$ & $\begin{array}{c}-0.098 \\
(0.016)\end{array}$ & $* *$ & $\begin{array}{l}-0.099 \\
(0.020)\end{array}$ & $* *$ & $\begin{array}{c}-0.092 \\
(0.021)\end{array}$ & $* *$ & $\begin{array}{l}-0.011 \\
(0.008)\end{array}$ & & $\begin{array}{c}0.014 \\
(0.004)\end{array}$ & ** \\
\hline Ukraine & 3 & $\begin{array}{c}0.026 \\
(0.007)\end{array}$ & $\begin{array}{l}-0.014 \\
(0.010)\end{array}$ & & $\begin{array}{l}-0.011 \\
(0.037)\end{array}$ & & $\begin{array}{c}0.001 \\
(0.044)\end{array}$ & & $\begin{array}{c}0.098 \\
(0.059)\end{array}$ & & $\begin{array}{c}0.106 \\
(0.061)\end{array}$ & & $\begin{array}{c}0.081 \\
(0.063)\end{array}$ & & $\begin{array}{c}0.015 \\
(0.005)\end{array}$ & * & $\begin{array}{l}-0.024 \\
(0.004)\end{array}$ & ** \\
\hline Uzbekistan & 2 & $\begin{array}{c}0.025 \\
(0.003)\end{array}$ & $\begin{array}{l}-0.007 \\
(0.004)\end{array}$ & & $\begin{array}{l}-0.008 \\
(0.018)\end{array}$ & & $\begin{array}{l}-0.006 \\
(0.017)\end{array}$ & & $\begin{array}{l}-0.049 \\
(0.041)\end{array}$ & & $\begin{array}{l}-0.060 \\
(0.027)\end{array}$ & & $\begin{array}{l}-0.049 \\
(0.025)\end{array}$ & & $\begin{array}{l}-0.044 \\
(0.004)\end{array}$ & ** & $\begin{array}{c}0.017 \\
(0.003)\end{array}$ & ** \\
\hline Uzbekistan & 3 & $\begin{array}{r}0.005 \\
(0.002) \\
\end{array}$ & $\begin{array}{c}0.000 \\
(0.002) \\
\end{array}$ & & $\begin{array}{c}0.001 \\
(0.009) \\
\end{array}$ & & $\begin{array}{l}-0.001 \\
(0.010) \\
\end{array}$ & & $\begin{array}{c}0.052 \\
(0.017) \\
\end{array}$ & * & $\begin{array}{c}0.048 \\
(0.015) \\
\end{array}$ & $*$ & $\begin{array}{c}0.051 \\
(0.020) \\
\end{array}$ & & $\begin{array}{r}0.012 \\
(0.002) \\
\end{array}$ & ** & $\begin{array}{c}-0.001 \\
(0.001) \\
\end{array}$ & \\
\hline
\end{tabular}

Age cell level regressions. Standard errors in parenthesis. * significant at 10\%. ** Significant at 5\%. 


\begin{tabular}{|c|c|c|c|c|c|c|c|c|c|c|c|c|c|c|c|}
\hline Country & $\begin{array}{c}\text { MICS } \\
\text { Rnd }\end{array}$ & $\begin{array}{c}\text { Paid Em } \\
\text { Base }\end{array}$ & $\begin{array}{l}\text { loyment } \\
\text { Change }\end{array}$ & $\begin{array}{c}\text { Unpaid } \\
\text { Economic } \\
\text { Activity }\end{array}$ & & $\begin{array}{c}\text { Economic } \\
\text { Activity }\end{array}$ & & $\begin{array}{l}\text { Unpaid } \\
\text { Hh. } \\
\text { Service }\end{array}$ & $\begin{array}{c}\text { Hh. Based } \\
\text { EA \& } \\
\text { Services } \\
\end{array}$ & & $\begin{array}{l}\text { Any } \\
\text { Work }\end{array}$ & $\begin{array}{l}\text { Attend } \\
\text { School }\end{array}$ & & \multicolumn{2}{|l|}{ Idle } \\
\hline Angola & 2 & $\begin{array}{c}0.056 \\
(0.007)\end{array}$ & $\begin{array}{l}-0.005 \\
(0.011)\end{array}$ & $\begin{array}{l}-0.049 \\
(0.015)\end{array}$ & $* *$ & $\begin{array}{l}-0.058 \\
(0.016)\end{array}$ & $* *$ & $\begin{array}{l}-0.002 \\
(0.019)\end{array}$ & $\begin{array}{l}-0.008 \\
(0.019)\end{array}$ & & $\begin{array}{l}-0.010 \\
(0.017)\end{array}$ & $\begin{array}{c}0.030 \\
(0.037)\end{array}$ & & $\begin{array}{c}0.001 \\
(0.011)\end{array}$ & \\
\hline Burundi & 2 & & & & & & & & & & & $\begin{array}{c}0.008 \\
(0.022)\end{array}$ & & & \\
\hline Burundi & 3 & & & & & & & & & & & $\begin{array}{c}0.047 \\
(0.018)\end{array}$ & $* *$ & & \\
\hline Cameroon & 2 & $\begin{array}{c}0.089 \\
(0.010)\end{array}$ & $\begin{array}{l}-0.008 \\
(0.016)\end{array}$ & $\begin{array}{l}-0.037 \\
(0.032)\end{array}$ & & $\begin{array}{l}-0.050 \\
(0.029)\end{array}$ & & $\begin{array}{l}-0.002 \\
(0.022)\end{array}$ & $\begin{array}{c}0.011 \\
(0.003)\end{array}$ & $*$ & $\begin{array}{l}-0.037 \\
(0.023)\end{array}$ & $\begin{array}{c}0.033 \\
(0.042)\end{array}$ & & $\begin{array}{c}0.021 \\
(0.018)\end{array}$ & \\
\hline Cameroon & 3 & $\begin{array}{c}0.060 \\
(0.009)\end{array}$ & $\begin{array}{l}-0.001 \\
(0.013)\end{array}$ & $\begin{array}{l}-0.067 \\
(0.037)\end{array}$ & & $\begin{array}{l}-0.062 \\
(0.039)\end{array}$ & & $\begin{array}{c}0.027 \\
(0.029)\end{array}$ & $\begin{array}{c}0.037 \\
(0.021)\end{array}$ & & $\begin{array}{c}0.012 \\
(0.023)\end{array}$ & $\begin{array}{c}0.010 \\
(0.040)\end{array}$ & & $\begin{array}{c}0.000 \\
(0.008)\end{array}$ & \\
\hline Central Afr. Republic & 2 & $\begin{array}{c}0.053 \\
(0.004)\end{array}$ & $\begin{array}{c}0.006 \\
(0.005)\end{array}$ & $\begin{array}{c}0.024 \\
(0.021)\end{array}$ & & $\begin{array}{c}0.036 \\
(0.022)\end{array}$ & & $\begin{array}{c}0.015 \\
(0.013)\end{array}$ & $\begin{array}{c}0.011 \\
(0.012)\end{array}$ & & $\begin{array}{c}0.017 \\
(0.010)\end{array}$ & $\begin{array}{l}-0.058 \\
(0.049)\end{array}$ & & $\begin{array}{l}-0.008 \\
(0.007)\end{array}$ & \\
\hline Central Afr. Republic & 3 & $\begin{array}{c}0.054 \\
(0.002)\end{array}$ & $\begin{array}{c}0.001 \\
(0.003)\end{array}$ & $\begin{array}{l}-0.022 \\
(0.015)\end{array}$ & & $\begin{array}{l}-0.027 \\
(0.017)\end{array}$ & & $\begin{array}{l}-0.032 \\
(0.015)\end{array}$ & $\begin{array}{l}-0.030 \\
(0.011)\end{array}$ & * & $\begin{array}{l}-0.090 \quad * * \\
(0.008)\end{array}$ & $\begin{array}{l}-0.074 \\
(0.049)\end{array}$ & & $\begin{array}{c}0.027 \\
(0.012)\end{array}$ & $*$ \\
\hline Chad & 2 & $\begin{array}{c}0.080 \\
(0.012)\end{array}$ & $\begin{array}{l}-0.009 \\
(0.019)\end{array}$ & $\begin{array}{l}-0.036 \\
(0.020)\end{array}$ & & $\begin{array}{l}-0.032 \\
(0.016)\end{array}$ & & $\begin{array}{c}0.011 \\
(0.027)\end{array}$ & $\begin{array}{l}-0.002 \\
(0.014)\end{array}$ & & $\begin{array}{l}-0.001 \\
(0.014)\end{array}$ & $\begin{array}{l}-0.088 \\
(0.070)\end{array}$ & & $\begin{array}{c}0.009 \\
(0.007)\end{array}$ & \\
\hline Comoros & 2 & & & & & & & & & & & $\begin{array}{c}-0.011 \\
(0.028)\end{array}$ & & & \\
\hline Cote d'Ivoire & 2 & $\begin{array}{c}0.045 \\
(0.005)\end{array}$ & $\begin{array}{c}-0.004 \\
(0.006)\end{array}$ & $\begin{array}{c}-0.004 \\
(0.025)\end{array}$ & & $\begin{array}{c}0.000 \\
(0.024)\end{array}$ & & $\begin{array}{c}0.005 \\
(0.025)\end{array}$ & $\begin{array}{c}0.013 \\
(0.023)\end{array}$ & & $\begin{array}{c}0.016 \\
(0.020)\end{array}$ & $\begin{array}{l}-0.075 \\
(0.041)\end{array}$ & & $\begin{array}{c}0.022 \\
(0.004)\end{array}$ & $* *$ \\
\hline Cote d'Ivoire & 3 & & & & & & & & & & & $\begin{array}{l}-0.050 \\
(0.044)\end{array}$ & & & \\
\hline DR Congo & 2 & $\begin{array}{c}0.085 \\
(0.007)\end{array}$ & $\begin{array}{l}-0.006 \\
(0.011)\end{array}$ & $\begin{array}{c}0.086 \\
(0.120)\end{array}$ & & $\begin{array}{c}0.082 \\
(0.130)\end{array}$ & & $\begin{array}{c}0.116 \\
(0.170)\end{array}$ & $\begin{array}{c}0.126 \\
(0.180)\end{array}$ & & $\begin{array}{c}0.125 \\
(0.184)\end{array}$ & $\begin{array}{l}-0.002 \\
(0.021)\end{array}$ & & $\begin{array}{l}-0.053 \\
(0.057)\end{array}$ & \\
\hline Djibouti & 3 & & & & & & & & & & & $\begin{array}{c}0.039 \\
(0.025)\end{array}$ & & & \\
\hline Equatorial Guinea & 2 & $\begin{array}{c}0.062 \\
(0.006)\end{array}$ & $\begin{array}{l}-0.007 \\
(0.009)\end{array}$ & $\begin{array}{c}0.070 \\
(0.052)\end{array}$ & & $\begin{array}{c}0.044 \\
(0.032)\end{array}$ & & $\begin{array}{l}-0.004 \\
(0.018)\end{array}$ & $\begin{array}{c}-0.011 \\
(0.015)\end{array}$ & & $\begin{array}{c}0.017 \\
(0.015)\end{array}$ & $\begin{array}{l}-0.051 \\
(0.021)\end{array}$ & $*$ & $\begin{array}{l}-0.002 \\
(0.005)\end{array}$ & \\
\hline Ghana & 3 & & & & & & & & & & & $\begin{array}{l}-0.075 \\
(0.028)\end{array}$ & $* *$ & & \\
\hline
\end{tabular}




\begin{tabular}{|c|c|c|c|c|c|c|c|c|c|c|c|c|c|c|}
\hline Country & $\begin{array}{l}\text { MICS } \\
\text { Rnd }\end{array}$ & $\begin{array}{c}\text { Paid Em } \\
\text { Base }\end{array}$ & $\begin{array}{l}\text { loyment } \\
\text { Change }\end{array}$ & & $\begin{array}{c}\text { Unpaid } \\
\text { Economic } \\
\text { Activity }\end{array}$ & & $\begin{array}{c}\text { Economic } \\
\text { Activity }\end{array}$ & & $\begin{array}{l}\text { Unpaid } \\
\text { Hh. } \\
\text { Service }\end{array}$ & $\begin{array}{c}\text { Hh. Based } \\
\text { EA \& } \\
\text { Services }\end{array}$ & & $\begin{array}{l}\text { Any } \\
\text { Work }\end{array}$ & $\begin{array}{l}\text { Attend } \\
\text { School }\end{array}$ & Idle \\
\hline Guinea Bissau & 2 & $\begin{array}{c}0.072 \\
(0.010)\end{array}$ & $\begin{array}{c}0.019 \\
(0.015)\end{array}$ & & $\begin{array}{l}-0.050 \\
(0.029)\end{array}$ & & $\begin{array}{l}-0.046 \\
(0.028)\end{array}$ & & $\begin{array}{l}-0.031 \\
(0.013)\end{array}$ & $\begin{array}{c}0.010 \\
(0.011)\end{array}$ & & $\begin{array}{c}0.013 \\
(0.017)\end{array}$ & $\begin{array}{l}-0.078 \\
(0.058)\end{array}$ & $\begin{array}{c}0.000 \\
(0.003)\end{array}$ \\
\hline Guinea Bissau & 3 & $\begin{array}{c}0.067 \\
(0.005)\end{array}$ & $\begin{array}{l}-0.016 \\
(0.007)\end{array}$ & $*$ & $\begin{array}{l}-0.010 \\
(0.029)\end{array}$ & & $\begin{array}{l}-0.008 \\
(0.030)\end{array}$ & & $\begin{array}{l}-0.002 \\
(0.024)\end{array}$ & $\begin{array}{c}0.041 \\
(0.021)\end{array}$ & & $\begin{array}{c}0.054 \\
(0.024)\end{array}$ & $\begin{array}{l}-0.044 \\
(0.052)\end{array}$ & $\begin{array}{c}0.017 \\
(0.018)\end{array}$ \\
\hline Kenya & 2 & $\begin{array}{c}0.071 \\
(0.006)\end{array}$ & $\begin{array}{c}0.020 \\
(0.011)\end{array}$ & & $\begin{array}{c}0.018 \\
(0.004)\end{array}$ & $* *$ & $\begin{array}{c}0.015 \\
(0.008)\end{array}$ & & $\begin{array}{l}-0.069 \\
(0.037)\end{array}$ & $\begin{array}{l}-0.010 \\
(0.041)\end{array}$ & & $\begin{array}{l}-0.056 \\
(0.032)\end{array}$ & $\begin{array}{c}0.012 \\
(0.036)\end{array}$ & $\begin{array}{c}0.002 \\
(0.010)\end{array}$ \\
\hline Lesotho & 2 & $\begin{array}{c}0.029 \\
(0.006)\end{array}$ & $\begin{array}{c}0.013 \\
(0.009)\end{array}$ & & $\begin{array}{c}0.039 \\
(0.020)\end{array}$ & & $\begin{array}{c}0.047 \\
(0.019)\end{array}$ & * & $\begin{array}{l}-0.079 * \\
(0.034)\end{array}$ & $\begin{array}{l}-0.033 \\
(0.036)\end{array}$ & & $\begin{array}{l}-0.077 * \\
(0.036)\end{array}$ & $\begin{array}{l}-0.012 \\
(0.022)\end{array}$ & $\begin{array}{c}0.011 \\
(0.012)\end{array}$ \\
\hline Madagascar & 2 & & & & & & & & & & & & $\begin{array}{c}0.047 \\
(0.052)\end{array}$ & \\
\hline Malawi & 3 & $\begin{array}{c}0.087 \\
(0.003)\end{array}$ & $\begin{array}{l}-0.002 \\
(0.005)\end{array}$ & & $\begin{array}{c}0.029 \\
(0.014)\end{array}$ & & $\begin{array}{c}0.026 \\
(0.010)\end{array}$ & $*$ & $\begin{array}{c}-0.002 \\
(0.013)\end{array}$ & $\begin{array}{l}-0.016 \\
(0.014)\end{array}$ & & $\begin{array}{l}-0.026 \\
(0.014)\end{array}$ & $\begin{array}{l}-0.019 \\
(0.023)\end{array}$ & $\begin{array}{c}0.013 \\
(0.000)\end{array}$ \\
\hline Mauritania & 3 & $\begin{array}{c}0.030 \\
(0.006)\end{array}$ & $\begin{array}{c}0.006 \\
(0.009)\end{array}$ & & $\begin{array}{l}-0.019 \\
(0.024)\end{array}$ & & $\begin{array}{l}-0.009 \\
(0.025)\end{array}$ & & $\begin{array}{l}-0.018 \\
(0.009)\end{array}$ & $\begin{array}{l}-0.015 \\
(0.009)\end{array}$ & & $\begin{array}{l}-0.010 \\
(0.016)\end{array}$ & $\begin{array}{c}0.066 \\
(0.036)\end{array}$ & $\begin{array}{l}0.035 \\
(0.009)\end{array}$ \\
\hline Niger & 2 & $\begin{array}{c}0.054 \\
(0.007)\end{array}$ & $\begin{array}{l}-0.018 \\
(0.012)\end{array}$ & & $\begin{array}{l}-0.088 \\
(0.020)\end{array}$ & $* *$ & $\begin{array}{l}-0.083 \\
(0.019)\end{array}$ & $* *$ & $\begin{array}{c}0.015 \\
(0.011)\end{array}$ & $\begin{array}{l}-0.027 \\
(0.010)\end{array}$ & $* *$ & $\begin{array}{l}-0.025 \\
(0.006)\end{array}$ & $\begin{array}{c}0.000 \\
(0.070)\end{array}$ & $\begin{array}{c}0.004 \\
(0.006)\end{array}$ \\
\hline Nigeria & 3 & $\begin{array}{c}0.045 \\
(0.004)\end{array}$ & $\begin{array}{c}0.023 \\
(0.006)\end{array}$ & $* *$ & $\begin{array}{l}-0.001 \\
(0.018)\end{array}$ & & $\begin{array}{c}0.005 \\
(0.018)\end{array}$ & & $\begin{array}{l}-0.015 \\
(0.011)\end{array}$ & $\begin{array}{l}-0.009 \\
(0.014)\end{array}$ & & $\begin{array}{c}0.008 \\
(0.013)\end{array}$ & $\begin{array}{l}-0.064 \\
(0.049)\end{array}$ & $\begin{array}{c}0.013 \\
(0.015)\end{array}$ \\
\hline Sao Tome and Principe & 2 & $\begin{array}{c}0.046 \\
(0.003)\end{array}$ & $\begin{array}{l}-0.010 \\
(0.003)\end{array}$ & $*$ & $\begin{array}{l}-0.003 \\
(0.024)\end{array}$ & & $\begin{array}{c}0.000 \\
(0.023)\end{array}$ & & $\begin{array}{l}-0.041 \\
(0.027)\end{array}$ & $\begin{array}{l}-0.045 \\
(0.026)\end{array}$ & & $\begin{array}{l}-0.037 \\
(0.027)\end{array}$ & $\begin{array}{l}-0.061 \\
(0.027)\end{array}$ & $\begin{array}{l}-0.003 \\
(0.003)\end{array}$ \\
\hline Senegal & 2 & & & & & & & & & & & & $\begin{array}{c}0.032 \\
(0.055)\end{array}$ & \\
\hline Sierra Leone & 2 & & & & & & & & & & & & $\begin{array}{l}-0.204 \quad * * \\
(0.043)\end{array}$ & \\
\hline Sierra Leone & 3 & & & & & & & & & & & & $\begin{array}{l}-0.048 \\
(0.058)\end{array}$ & \\
\hline Swaziland & 2 & $\begin{array}{c}0.048 \\
(0.006)\end{array}$ & $\begin{array}{l}-0.017 \\
(0.006)\end{array}$ & * & $\begin{array}{l}-0.012 \\
(0.031)\end{array}$ & & $\begin{array}{l}-0.008 \\
(0.031)\end{array}$ & & $\begin{array}{c}0.000 \\
(0.018)\end{array}$ & $\begin{array}{c}0.003 \\
(0.014)\end{array}$ & & $\begin{array}{l}-0.005 \\
(0.009)\end{array}$ & $\begin{array}{c}0.025 \\
(0.034)\end{array}$ & $\begin{array}{l}-0.011 \\
(0.008)\end{array}$ \\
\hline Togo & 2 & $\begin{array}{c}0.218 \\
(0.023)\end{array}$ & $\begin{array}{l}-0.009 \\
(0.035)\end{array}$ & & $\begin{array}{c}0.092 \\
(0.027)\end{array}$ & $* *$ & $\begin{array}{c}0.066 \\
(0.045)\end{array}$ & & $\begin{array}{c}0.024 \\
(0.011)\end{array}$ & $\begin{array}{c}0.022 \\
(0.008)\end{array}$ & $*$ & $\begin{array}{c}0.028 \\
(0.015)\end{array}$ & $\begin{array}{c}0.003 \\
(0.013)\end{array}$ & $\begin{array}{l}-0.008 \\
(0.012)\end{array}$ \\
\hline
\end{tabular}


Table 6A: Changes in Time Allocation at the Age of Relaxation of Minimum Age Laws (Non-Hazardous Work), Africa

\begin{tabular}{|c|c|c|c|c|c|c|c|c|c|c|c|}
\hline Country & $\begin{array}{c}\text { MICS } \\
\text { Rnd }\end{array}$ & $\begin{array}{c}\text { Paid Em } \\
\text { Base }\end{array}$ & $\begin{array}{l}\text { loyment } \\
\text { Change }\end{array}$ & & $\begin{array}{l}\text { Unpaid } \\
\text { Economic } \\
\text { Activity }\end{array}$ & $\begin{array}{c}\text { Economic } \\
\text { Activity }\end{array}$ & $\begin{array}{l}\text { Unpaid } \\
\text { Hh. } \\
\text { Service }\end{array}$ & $\begin{array}{c}\text { Hh. Based } \\
\text { EA \& } \\
\text { Services }\end{array}$ & $\begin{array}{c}\text { Any } \\
\text { Work }\end{array}$ & $\begin{array}{l}\text { Attend } \\
\text { School }\end{array}$ & Idle \\
\hline Togo & 3 & $\begin{array}{c}0.180 \\
(0.029)\end{array}$ & $\begin{array}{c}-0.094 \\
(0.031)\end{array}$ & * & $\begin{array}{l}-0.005 \\
(0.035)\end{array}$ & $\begin{array}{c}0.029 \\
(0.026)\end{array}$ & $\begin{array}{l}-0.057 * \\
(0.018)\end{array}$ & $\begin{array}{l}-0.013 \\
(0.020)\end{array}$ & $\begin{array}{l}-0.017 \\
(0.015)\end{array}$ & $\begin{array}{l}-0.072 \\
(0.041)\end{array}$ & $\begin{array}{c}0.003 \\
(0.002)\end{array}$ \\
\hline
\end{tabular}

Age cell level regressions. Standard errors in parenthesis. * significant at 10\%. ** Significant at 5\%. 
Table 6b: Changes in Time Allocation at the Age of Relaxation of Minimum Age Laws (Non-Hazardous Work), Non-Africa

\begin{tabular}{|c|c|c|c|c|c|c|c|c|c|c|c|c|c|}
\hline Country & $\begin{array}{c}\text { MICS } \\
\text { Rnd }\end{array}$ & $\begin{array}{c}\text { Paid Em } \\
\text { Base }\end{array}$ & $\begin{array}{c}\text { ployment } \\
\text { Change }\end{array}$ & & $\begin{array}{l}\text { Unpaid } \\
\text { Economic } \\
\text { Activity }\end{array}$ & $\begin{array}{c}\text { Economic } \\
\text { Activity }\end{array}$ & $\begin{array}{l}\text { Unpaid } \\
\text { Hh. } \\
\text { Services }\end{array}$ & & $\begin{array}{c}\text { Hh. Based } \\
\text { EA \& } \\
\text { Services }\end{array}$ & $\begin{array}{c}\text { Any } \\
\text { Work }\end{array}$ & $\begin{array}{l}\text { Attend } \\
\text { School }\end{array}$ & & Idle \\
\hline Albania & 2 & & & & & & & & & & $\begin{array}{c}0.041 \\
(0.058)\end{array}$ & & \\
\hline Albania & 3 & & & & & & & & & & $\begin{array}{c}0.158 \\
(0.056)\end{array}$ & $* *$ & \\
\hline Azerbaijan & 2 & $\begin{array}{c}0.003 \\
(0.002)\end{array}$ & $\begin{array}{c}0.004 \\
(0.003)\end{array}$ & & $\begin{array}{l}-0.001 \\
(0.019)\end{array}$ & $\begin{array}{c}0.001 \\
(0.017)\end{array}$ & $\begin{array}{l}-0.061 \\
(0.027)\end{array}$ & $*$ & $\begin{array}{l}-0.059 \\
(0.029)\end{array}$ & $\begin{array}{l}-0.056 \\
(0.027)\end{array}$ & $\begin{array}{l}-0.007 \\
(0.016)\end{array}$ & & $\begin{array}{c}0.007 \\
(0.011)\end{array}$ \\
\hline Bangladesh & 3 & $\begin{array}{c}0.041 \\
(0.003)\end{array}$ & $\begin{array}{c}0.010 \\
(0.004)\end{array}$ & $* *$ & $\begin{array}{c}0.026 \\
(0.015)\end{array}$ & $\begin{array}{c}0.007 \\
(0.013)\end{array}$ & $\begin{array}{c}0.003 \\
(0.004)\end{array}$ & & $\begin{array}{c}0.024 \\
(0.003)\end{array}$ & $\begin{array}{cc}* & 0.027 \\
& (0.014)\end{array}$ & $\begin{array}{l}-0.089 \\
(0.018)\end{array}$ & $* *$ & $\begin{array}{c}0.005 \\
(0.008)\end{array}$ \\
\hline Belarus & 3 & $\begin{array}{c}0.012 \\
(0.010)\end{array}$ & $\begin{array}{l}-0.004 \\
(0.015)\end{array}$ & & $\begin{array}{l}-0.018 \\
(0.039)\end{array}$ & $\begin{array}{l}-0.021 \\
(0.045)\end{array}$ & $\begin{array}{l}-0.050 \\
(0.034)\end{array}$ & & $\begin{array}{l}-0.048 \\
(0.033)\end{array}$ & $\begin{array}{c}0.015 \\
(0.034)\end{array}$ & $\begin{array}{l}-0.006 \\
(0.005)\end{array}$ & & $\begin{array}{c}0.006 \\
(0.005)\end{array}$ \\
\hline Bolivia & 2 & $\begin{array}{c}0.057 \\
(0.006)\end{array}$ & $\begin{array}{c}0.030 \\
(0.009)\end{array}$ & $* *$ & $\begin{array}{l}-0.022 \\
(0.024)\end{array}$ & $\begin{array}{c}0.011 \\
(0.023)\end{array}$ & $\begin{array}{c}0.035 \\
(0.041)\end{array}$ & & $\begin{array}{c}0.026 \\
(0.030)\end{array}$ & $\begin{array}{c}0.041 \\
(0.024)\end{array}$ & $\begin{array}{l}-0.003 \\
(0.023)\end{array}$ & & $\begin{array}{c}0.002 \\
(0.001)\end{array}$ \\
\hline Bosnia and Herzegovina & 2 & & & & & & & & & & $\begin{array}{c}0.007 \\
(0.007)\end{array}$ & & \\
\hline Bosnia and Herzegovina & 3 & & & & & & & & & & $\begin{array}{c}0.016 \\
(0.014)\end{array}$ & & \\
\hline Dominican Republic & 2 & $\begin{array}{c}0.084 \\
(0.008)\end{array}$ & $\begin{array}{c}0.018 \\
(0.012)\end{array}$ & & $\begin{array}{c}0.013 \\
(0.037)\end{array}$ & $\begin{array}{c}0.033 \\
(0.042)\end{array}$ & $\begin{array}{l}-0.128 \\
(0.056)\end{array}$ & & $\begin{array}{c}-0.062 \\
(0.070)\end{array}$ & $\begin{array}{c}0.025 \\
(0.029)\end{array}$ & $\begin{array}{c}0.023 \\
(0.022)\end{array}$ & & $\begin{array}{c}0.005 \\
(0.009)\end{array}$ \\
\hline Georgia & 3 & $\begin{array}{c}0.025 \\
(0.004)\end{array}$ & $\begin{array}{l}-0.009 \\
(0.006)\end{array}$ & & $\begin{array}{l}-0.047 \\
(0.018)\end{array}$ & $\begin{array}{l}-0.076 \\
(0.028)\end{array}$ & $\begin{array}{l}-0.047 \\
(0.043)\end{array}$ & & $\begin{array}{l}-0.044 \\
(0.042)\end{array}$ & $\begin{array}{l}-0.046 \\
(0.046)\end{array}$ & $\begin{array}{l}-0.004 \\
(0.006)\end{array}$ & & $\begin{array}{c}0.002 \\
(0.003)\end{array}$ \\
\hline Guyana & 2 & & & & & & & & & & $\begin{array}{l}-0.074 \\
(0.012)\end{array}$ & $* *$ & \\
\hline Guyana & 3 & & & & & & & & & & $\begin{array}{l}-0.031 \\
(0.015)\end{array}$ & & \\
\hline Iraq & 2 & & & & & & & & & & $\begin{array}{c}0.033 \\
(0.018)\end{array}$ & & \\
\hline Iraq & 3 & & & & & & & & & & $\begin{array}{c}0.013 \\
(0.018)\end{array}$ & & \\
\hline Jamaica & 3 & $\begin{array}{c}0.016 \\
(0.005)\end{array}$ & $\begin{array}{c}0.001 \\
(0.006)\end{array}$ & & $\begin{array}{l}-0.062 \\
(0.013)\end{array}$ & $\begin{array}{l}-0.069 \\
(0.024)\end{array}$ & $\begin{array}{l}-0.021 \\
(0.013)\end{array}$ & & $\begin{array}{l}-0.027 \\
(0.011)\end{array}$ & $\begin{array}{l}-0.018 \\
(0.011)\end{array}$ & $\begin{array}{l}-0.005 \\
(0.005)\end{array}$ & & $\begin{array}{c}0.002 \\
(0.003)\end{array}$ \\
\hline
\end{tabular}


Table 6b: Changes in Time Allocation at the Age of Relaxation of Minimum Age Laws (Non-Hazardous Work), Non-Africa

\begin{tabular}{|c|c|c|c|c|c|c|c|c|c|c|c|c|c|c|c|}
\hline Country & $\begin{array}{c}\text { MICS } \\
\text { Rnd }\end{array}$ & $\begin{array}{c}\text { Paid Em } \\
\text { Base }\end{array}$ & $\begin{array}{c}\text { ployment } \\
\text { Change }\end{array}$ & $\begin{array}{c}\text { Unpaid } \\
\text { Economic } \\
\text { Activity }\end{array}$ & & $\begin{array}{c}\text { Economic } \\
\text { Activity }\end{array}$ & & $\begin{array}{c}\text { Unpaid } \\
\text { Hh. } \\
\text { Services }\end{array}$ & & $\begin{array}{c}\text { Hh. Based } \\
\text { EA \& } \\
\text { Services }\end{array}$ & & $\begin{array}{c}\text { Any } \\
\text { Work }\end{array}$ & $\begin{array}{l}\text { Attend } \\
\text { School }\end{array}$ & & Idle \\
\hline Kazakhstan & 3 & & & & & & & & & & & & $\begin{array}{l}-0.007 \\
(0.003)\end{array}$ & $*$ & \\
\hline Kyrgyzstan & 3 & $\begin{array}{c}0.003 \\
(0.001)\end{array}$ & $\begin{array}{c}0.002 \\
(0.002)\end{array}$ & $\begin{array}{c}0.011 \\
(0.019)\end{array}$ & & $\begin{array}{c}0.011 \\
(0.021)\end{array}$ & & $\begin{array}{c}0.022 \\
(0.065)\end{array}$ & & $\begin{array}{c}0.027 \\
(0.068)\end{array}$ & & $\begin{array}{c}0.033 \\
(0.072)\end{array}$ & $\begin{array}{c}0.015 \\
(0.015)\end{array}$ & & $\begin{array}{l}-0.017 * \\
(0.007)\end{array}$ \\
\hline Lao PDR & 2 & & & & & & & & & & & & $\begin{array}{l}-0.086 \\
(0.063)\end{array}$ & & \\
\hline Lao PDR & 3 & & & & & & & & & & & & $\begin{array}{c}0.026 \\
(0.035)\end{array}$ & & \\
\hline Macedonia & 3 & & & & & & & & & & & & $\begin{array}{l}-0.191 \\
(0.024)\end{array}$ & $* *$ & \\
\hline Moldova & 2 & & & & & & & & & & & & $\begin{array}{l}-0.123 \\
(0.012)\end{array}$ & $* *$ & \\
\hline Mongolia & 2 & $\begin{array}{c}0.019 \\
(0.003)\end{array}$ & $\begin{array}{l}-0.003 \\
(0.005)\end{array}$ & $\begin{array}{c}0.013 \\
(0.014)\end{array}$ & & $\begin{array}{l}0.010 \\
(0.014)\end{array}$ & & $\begin{array}{l}-0.008 \\
(0.015)\end{array}$ & & $\begin{array}{c}0.053 \\
(0.023)\end{array}$ & & $\begin{array}{c}0.055 \\
(0.023)\end{array}$ & $\begin{array}{l}-0.097 \\
(0.045)\end{array}$ & & $\begin{array}{c}-0.002 \\
(0.006)\end{array}$ \\
\hline Mongolia & 3 & $\begin{array}{c}0.004 \\
(0.004)\end{array}$ & $\begin{array}{c}0.004 \\
(0.006)\end{array}$ & $\begin{array}{l}-0.016 \\
(0.010)\end{array}$ & & $\begin{array}{l}-0.030 \\
(0.007)\end{array}$ & $* *$ & $\begin{array}{c}0.036 \\
(0.017)\end{array}$ & & $\begin{array}{c}0.030 \\
(0.012)\end{array}$ & $*$ & $\begin{array}{c}0.029 \\
(0.020)\end{array}$ & $\begin{array}{l}-0.012 \\
(0.016)\end{array}$ & & $\begin{array}{c}0.016 \\
(0.007)\end{array}$ \\
\hline Montenegro & 3 & & & & & & & & & & & & $\begin{array}{l}-0.028 \\
(0.008)\end{array}$ & $* *$ & \\
\hline Philippines & 2 & $\begin{array}{c}0.080 \\
(0.007)\end{array}$ & $\begin{array}{c}0.001 \\
(0.012)\end{array}$ & $\begin{array}{c}0.081 \\
(0.037)\end{array}$ & & $\begin{array}{l}-0.008 \\
(0.018)\end{array}$ & & $\begin{array}{c}0.007 \\
(0.023)\end{array}$ & & $\begin{array}{c}0.004 \\
(0.023)\end{array}$ & & $\begin{array}{c}0.001 \\
(0.022)\end{array}$ & $\begin{array}{c}0.095 \\
(0.027)\end{array}$ & $* *$ & $\begin{array}{c}0.015 \\
(0.003)\end{array}$ \\
\hline Serbia & 3 & & & & & & & & & & & & $\begin{array}{l}-0.004 \\
(0.006)\end{array}$ & & \\
\hline Suriname & 3 & $\begin{array}{c}0.037 \\
(0.005)\end{array}$ & $\begin{array}{c}0.009 \\
(0.007)\end{array}$ & $\begin{array}{c}0.065 \\
(0.019)\end{array}$ & * & $\begin{array}{c}0.023 \\
(0.011)\end{array}$ & & $\begin{array}{c}0.098 \\
(0.033)\end{array}$ & * & $\begin{array}{c}0.096 \\
(0.032)\end{array}$ & $*$ & $\begin{array}{l}0.108 \quad * * \\
(0.030)\end{array}$ & $\begin{array}{l}-0.003 \\
(0.015)\end{array}$ & & $\begin{array}{l}-0.004 \\
(0.005)\end{array}$ \\
\hline Syria & 3 & & & & & & & & & & & & $\begin{array}{c}0.126 \\
(0.027)\end{array}$ & $* *$ & \\
\hline Tajikistan & 2 & & & & & & & & & & & & $\begin{array}{l}-0.038 \\
(0.023)\end{array}$ & & \\
\hline Tajikistan & 3 & & & & & & & & & & & & $\begin{array}{l}-0.080 \\
(0.023)\end{array}$ & ** & \\
\hline
\end{tabular}


Table 6b: Changes in Time Allocation at the Age of Relaxation of Minimum Age Laws (Non-Hazardous Work), Non-Africa

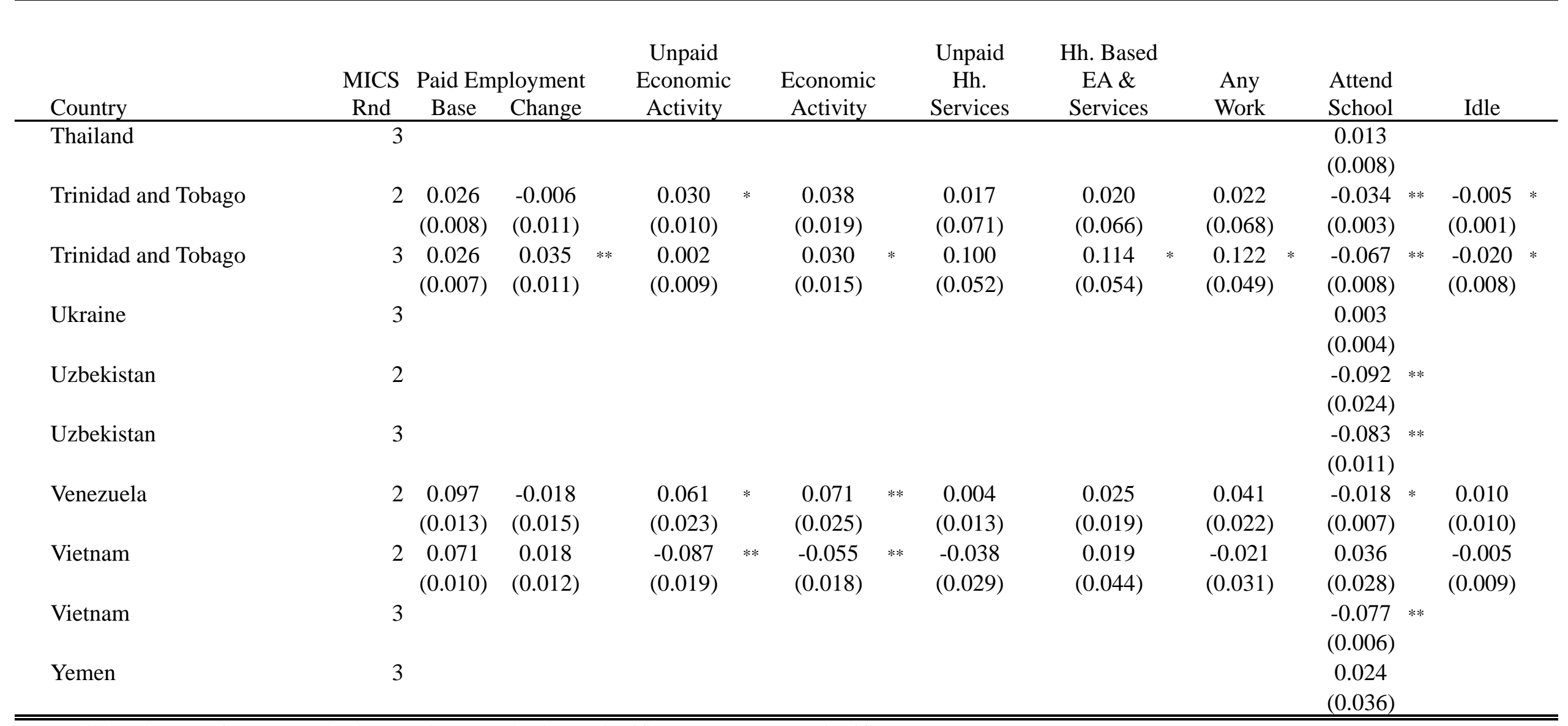

Age cell level regressions. Standard errors in parenthesis. * significant at 10\%. ** Significant at 5\%. 
Table 7A: Changes in Time Allocation at the Age of Relaxation of Compulsory Schooling Laws, Africa

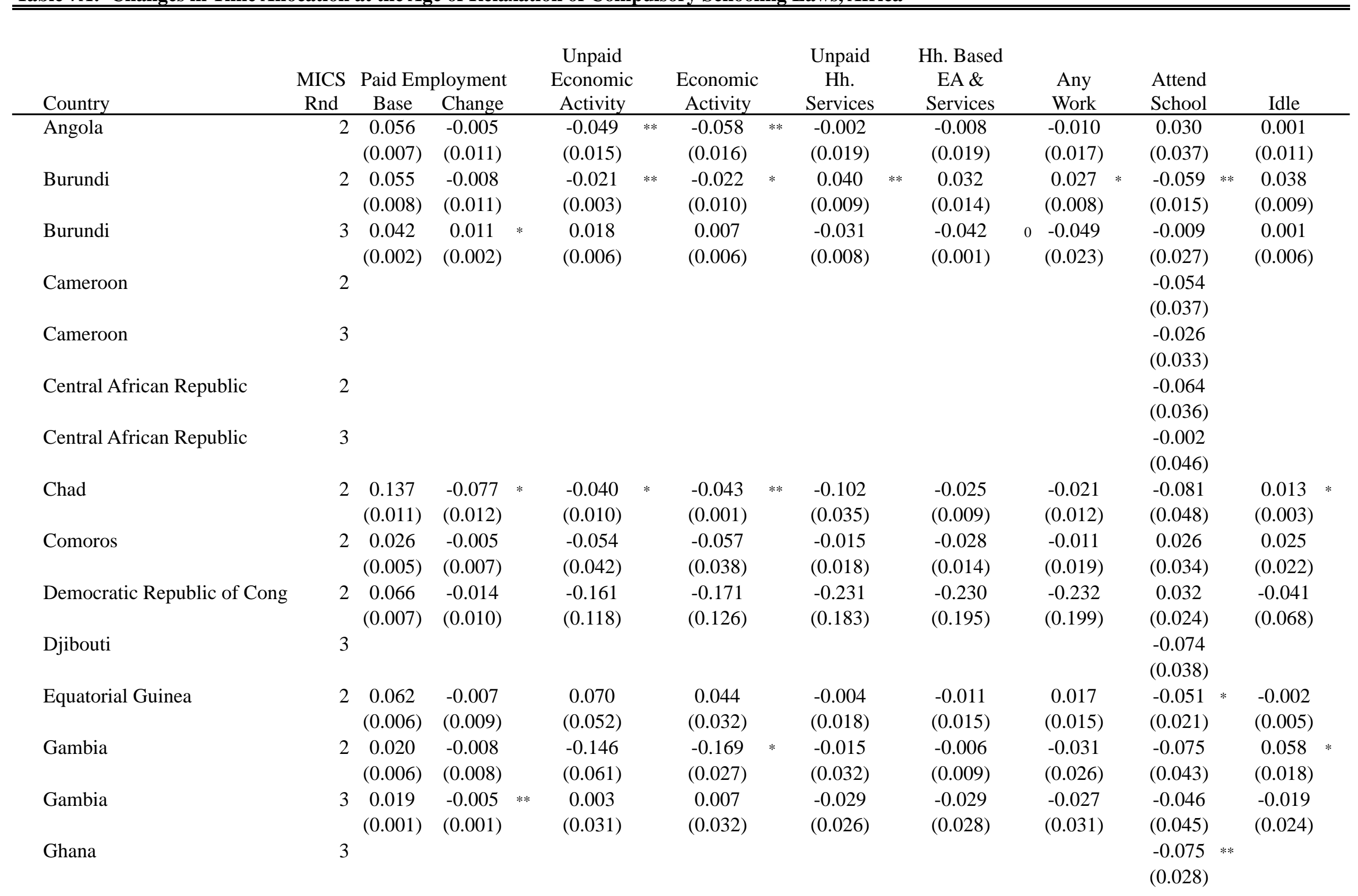




\begin{tabular}{|c|c|c|c|c|c|c|c|c|c|c|c|c|c|c|c|}
\hline Country & $\begin{array}{c}\text { MICS } \\
\text { Rnd }\end{array}$ & $\begin{array}{c}\text { Paid Em } \\
\text { Base }\end{array}$ & $\begin{array}{c}\text { ployment } \\
\text { Change }\end{array}$ & & $\begin{array}{l}\text { Unpaid } \\
\text { Economic } \\
\text { Activity }\end{array}$ & & $\begin{array}{c}\text { Economic } \\
\text { Activity }\end{array}$ & & $\begin{array}{c}\text { Unpaid } \\
\text { Hh. } \\
\text { Services }\end{array}$ & & $\begin{array}{c}\text { Hh. Based } \\
\text { EA \& } \\
\text { Services }\end{array}$ & $\begin{array}{c}\text { Any } \\
\text { Work }\end{array}$ & & $\begin{array}{l}\text { Attend } \\
\text { School }\end{array}$ & Idle \\
\hline Guinea Bissau & 2 & $\begin{array}{c}0.080 \\
(0.008)\end{array}$ & $\begin{array}{c}-0.023 \\
(0.012)\end{array}$ & & $\begin{array}{l}-0.035 \\
(0.027)\end{array}$ & & $\begin{array}{l}-0.034 \\
(0.026)\end{array}$ & & $\begin{array}{c}0.071 \\
(0.001)\end{array}$ & $* *$ & $\begin{array}{c}0.013 \\
(0.011)\end{array}$ & $\begin{array}{c}0.018 \\
(0.019)\end{array}$ & & $\begin{array}{l}-0.080 \\
(0.052)\end{array}$ & $\begin{array}{l}-0.011 \\
(0.003)\end{array}$ \\
\hline Guinea Bissau & 3 & $\begin{array}{c}0.064 \\
(0.005)\end{array}$ & $\begin{array}{l}-0.009 \\
(0.007)\end{array}$ & & $\begin{array}{l}-0.031 \\
(0.030)\end{array}$ & & $\begin{array}{l}-0.041 \\
(0.028)\end{array}$ & & $\begin{array}{c}0.029 \\
(0.007)\end{array}$ & * & $\begin{array}{l}-0.031 \\
(0.024)\end{array}$ & $\begin{array}{l}-0.035 \\
(0.027)\end{array}$ & & $\begin{array}{c}0.053 \\
(0.038)\end{array}$ & $\begin{array}{c}0.033 \\
(0.005)\end{array}$ \\
\hline Kenya & 2 & $\begin{array}{c}0.051 \\
(0.008)\end{array}$ & $\begin{array}{l}-0.002 \\
(0.011)\end{array}$ & & $\begin{array}{l}-0.004 \\
(0.002)\end{array}$ & & $\begin{array}{l}-0.005 \\
(0.010)\end{array}$ & & $\begin{array}{l}-0.007 \\
(0.027)\end{array}$ & & $\begin{array}{l}-0.007 \\
(0.027)\end{array}$ & $\begin{array}{l}-0.098 \\
(0.054)\end{array}$ & & $\begin{array}{c}0.036 \\
(0.011)\end{array}$ & $\begin{array}{c}0.007 \\
(0.009)\end{array}$ \\
\hline Madagascar & 2 & & & & & & & & & & & & & $\begin{array}{c}0.047 \\
(0.052)\end{array}$ & \\
\hline Mauritania & 3 & & & & & & & & & & & & & $\begin{array}{l}-0.111 \\
(0.050)\end{array}$ & \\
\hline Niger & 2 & $\begin{array}{c}0.042 \\
(0.007)\end{array}$ & $\begin{array}{c}0.014 \\
(0.010)\end{array}$ & & $\begin{array}{l}-0.029 \\
(0.014)\end{array}$ & & $\begin{array}{l}-0.020 \\
(0.017)\end{array}$ & & $\begin{array}{l}-0.047 \\
(0.002)\end{array}$ & $* *$ & $\begin{array}{c}0.001 \\
(0.010)\end{array}$ & $\begin{array}{c}0.001 \\
(0.007)\end{array}$ & & $\begin{array}{l}-0.085 \\
(0.059)\end{array}$ & $\begin{array}{c}0.003 \\
(0.006)\end{array}$ \\
\hline Nigeria & 3 & $\begin{array}{c}0.045 \\
(0.004)\end{array}$ & $\begin{array}{c}0.023 \\
(0.006)\end{array}$ & ** & $\begin{array}{l}-0.001 \\
(0.018)\end{array}$ & & $\begin{array}{c}0.005 \\
(0.018)\end{array}$ & & $\begin{array}{l}-0.015 \\
(0.011)\end{array}$ & & $\begin{array}{l}-0.009 \\
(0.014)\end{array}$ & $\begin{array}{c}0.008 \\
(0.013)\end{array}$ & & $\begin{array}{l}-0.064 \\
(0.049)\end{array}$ & $\begin{array}{c}0.013 \\
(0.015)\end{array}$ \\
\hline Rwanda & 2 & $\begin{array}{l}-0.004 \\
(0.004)\end{array}$ & $\begin{array}{c}0.045 \\
(0.004)\end{array}$ & $*$ & $\begin{array}{l}-0.032 \\
(0.031)\end{array}$ & & $\begin{array}{l}-0.023 \\
(0.030)\end{array}$ & & $\begin{array}{c}0.011 \\
(0.004)\end{array}$ & & $\begin{array}{c}0.023 \\
(0.011)\end{array}$ & $\begin{array}{c}0.030 \\
(0.007)\end{array}$ & $*$ & $\begin{array}{c}0.018 \\
(0.013)\end{array}$ & $\begin{array}{l}-0.015 \\
(0.010)\end{array}$ \\
\hline Sao Tome and Principe & 2 & $\begin{array}{c}0.032 \\
(0.004)\end{array}$ & $\begin{array}{c}0.002 \\
(0.005)\end{array}$ & & $\begin{array}{c}0.000 \\
(0.029)\end{array}$ & & $\begin{array}{l}-0.002 \\
(0.028)\end{array}$ & & $\begin{array}{l}-0.020 \\
(0.030)\end{array}$ & & $\begin{array}{l}-0.020 \\
(0.029)\end{array}$ & $\begin{array}{l}-0.021 \\
(0.031)\end{array}$ & & $\begin{array}{l}-0.049 \\
(0.027)\end{array}$ & $\begin{array}{c}0.007 \\
(0.004)\end{array}$ \\
\hline Senegal & 2 & & & & & & & & & & & & & $\begin{array}{c}0.076 \\
(0.050)\end{array}$ & \\
\hline Sierra Leone & 2 & $\begin{array}{c}0.052 \\
(0.009)\end{array}$ & $\begin{array}{l}-0.020 \\
(0.010)\end{array}$ & & $\begin{array}{c}0.012 \\
(0.037)\end{array}$ & & $\begin{array}{c}0.020 \\
(0.038)\end{array}$ & & $\begin{array}{c}0.077 \\
(0.018)\end{array}$ & & $\begin{array}{c}0.032 \\
(0.009)\end{array}$ & $\begin{array}{c}0.035 \\
(0.004)\end{array}$ & $*$ & $\begin{array}{l}-0.013 \\
(0.065)\end{array}$ & $\begin{array}{l}-0.006 \\
(0.016)\end{array}$ \\
\hline Sierra Leone & 3 & $\begin{array}{c}0.025 \\
(0.011)\end{array}$ & $\begin{array}{c}0.019 \\
(0.012)\end{array}$ & & $\begin{array}{l}-0.026 \\
(0.047)\end{array}$ & & $\begin{array}{l}-0.024 \\
(0.040)\end{array}$ & & $\begin{array}{l}-0.009 \\
(0.005)\end{array}$ & & $\begin{array}{l}-0.012 \\
(0.006)\end{array}$ & $\begin{array}{l}-0.011 \\
(0.001)\end{array}$ & ${ }^{* *}$ & $\begin{array}{l}-0.041 \\
(0.047)\end{array}$ & $\begin{array}{c}0.005 \\
(0.002)\end{array}$ \\
\hline Somalia & 3 & $\begin{array}{c}0.039 \\
(0.003)\end{array}$ & $\begin{array}{l}-0.013 \\
(0.003)\end{array}$ & $* *$ & $\begin{array}{l}-0.028 \\
(0.024)\end{array}$ & & $\begin{array}{l}-0.024 \\
(0.023)\end{array}$ & & $\begin{array}{l}-0.044 \\
(0.029)\end{array}$ & & $\begin{array}{c}0.001 \\
(0.021)\end{array}$ & $\begin{array}{c}0.002 \\
(0.021)\end{array}$ & & $\begin{array}{l}-0.109 \\
(0.053)\end{array}$ & $\begin{array}{l}-0.036 \\
(0.022)\end{array}$ \\
\hline Sudan, Northern & 2 & $\begin{array}{c}0.063 \\
(0.006)\end{array}$ & $\begin{array}{c}0.008 \\
(0.009)\end{array}$ & & $\begin{array}{l}-0.003 \\
(0.032)\end{array}$ & & $\begin{array}{l}-0.004 \\
(0.034)\end{array}$ & & $\begin{array}{c}0.032 \\
(0.002)\end{array}$ & $* *$ & $\begin{array}{c}0.054 \\
(0.014)\end{array}$ & $\begin{array}{c}0.024 \\
(0.016)\end{array}$ & & $\begin{array}{l}-0.058 \\
(0.076)\end{array}$ & $\begin{array}{l}-0.026 \\
(0.034)\end{array}$ \\
\hline Sudan, Southern & 2 & $\begin{array}{c}0.087 \\
(0.012)\end{array}$ & $\begin{array}{l}-0.041 \\
(0.018)\end{array}$ & * & $\begin{array}{c}0.219 \\
(0.007)\end{array}$ & $* *$ & $\begin{array}{c}0.200 \\
(0.034)\end{array}$ & $* *$ & $\begin{array}{c}0.035 \\
(0.099)\end{array}$ & & $\begin{array}{l}-0.002 \\
(0.095)\end{array}$ & $\begin{array}{c}0.008 \\
(0.098)\end{array}$ & & $\begin{array}{l}-0.041 \text { ** } \\
(0.007)\end{array}$ & $\begin{array}{c}0.058 \\
(0.029)\end{array}$ \\
\hline
\end{tabular}


Table 7A: Changes in Time Allocation at the Age of Relaxation of Compulsory Schooling Laws, Africa

\begin{tabular}{|c|c|c|c|c|c|c|c|c|c|c|c|c|}
\hline Country & $\begin{array}{c}\text { MICS } \\
\text { Rnd }\end{array}$ & $\begin{array}{c}\text { Paid Em } \\
\text { Base }\end{array}$ & $\begin{array}{c}\text { ployment } \\
\text { Change }\end{array}$ & $\begin{array}{l}\text { Unpaid } \\
\text { Economic } \\
\text { Activity }\end{array}$ & $\begin{array}{c}\text { Economic } \\
\text { Activity }\end{array}$ & $\begin{array}{l}\text { Unpaid } \\
\text { Hh. } \\
\text { Services }\end{array}$ & & $\begin{array}{c}\text { Hh. Based } \\
\text { EA \& } \\
\text { Services }\end{array}$ & & $\begin{array}{c}\text { Any } \\
\text { Work }\end{array}$ & $\begin{array}{l}\text { Attend } \\
\text { School }\end{array}$ & Idle \\
\hline Togo & 2 & $\begin{array}{c}0.250 \\
(0.017)\end{array}$ & $\begin{array}{c}0.017 \\
(0.031)\end{array}$ & $\begin{array}{l}-0.010 \\
(0.043)\end{array}$ & $\begin{array}{c}0.010 \\
(0.043)\end{array}$ & $\begin{array}{l}-0.054 \\
(0.015)\end{array}$ & $* *$ & $\begin{array}{l}-0.034 \\
(0.015)\end{array}$ & $*$ & $\begin{array}{l}-0.037 \\
(0.024)\end{array}$ & $\begin{array}{l}-0.042 \\
(0.033)\end{array}$ & $\begin{array}{c}0.022 \\
(0.014)\end{array}$ \\
\hline Togo & 3 & & & & & & & & & & $\begin{array}{c}0.067 \\
(0.042)\end{array}$ & \\
\hline
\end{tabular}

Age cell level regressions. Standard errors in parenthesis. * significant at 10\%. ** Significant at 5\%. 
Table 7B: Changes in Time Allocation at the Age of Relaxation of Compulsory Schooling Laws, Non-Africa

\begin{tabular}{|c|c|c|c|c|c|c|c|c|c|c|c|c|c|c|c|c|}
\hline Country & $\begin{array}{c}\text { MICS } \\
\text { Rnd }\end{array}$ & $\begin{array}{c}\text { Paid Em } \\
\text { Base }\end{array}$ & $\begin{array}{c}\text { ployment } \\
\text { Change }\end{array}$ & & $\begin{array}{c}\text { Unpaid } \\
\text { Economic } \\
\text { Activity }\end{array}$ & & $\begin{array}{c}\text { Economic } \\
\text { Activity }\end{array}$ & & $\begin{array}{c}\text { Unpaid } \\
\text { Hh. } \\
\text { Services }\end{array}$ & & $\begin{array}{c}\text { Hh. Based } \\
\text { EA \& } \\
\text { Services } \\
\end{array}$ & & $\begin{array}{l}\text { Any } \\
\text { Work }\end{array}$ & $\begin{array}{l}\text { Attend } \\
\text { School }\end{array}$ & & Idle \\
\hline Albania & 2 & $\begin{array}{c}0.025 \\
(0.007)\end{array}$ & $\begin{array}{l}-0.005 \\
(0.008)\end{array}$ & & $\begin{array}{c}0.109 \\
(0.059)\end{array}$ & & $\begin{array}{c}0.098 \\
(0.052)\end{array}$ & & $\begin{array}{c}0.019 \\
(0.055)\end{array}$ & & $\begin{array}{c}0.034 \\
(0.024)\end{array}$ & & $\begin{array}{c}0.026 \\
(0.021)\end{array}$ & $\begin{array}{c}0.118 \\
(0.040)\end{array}$ & * & $\begin{array}{l}-0.024 \\
(0.032)\end{array}$ \\
\hline Albania & 3 & $\begin{array}{c}0.010 \\
(0.005)\end{array}$ & $\begin{array}{l}-0.001 \\
(0.007)\end{array}$ & & $\begin{array}{l}-0.060 \\
(0.025)\end{array}$ & * & $\begin{array}{l}-0.061 \\
(0.026)\end{array}$ & $*$ & $\begin{array}{l}-0.139 \\
(0.053)\end{array}$ & $*$ & $\begin{array}{l}-0.153 \\
(0.044)\end{array}$ & $* *$ & $\begin{array}{l}-0.149 \quad * * \\
(0.043)\end{array}$ & $\begin{array}{l}-0.149 \\
(0.012)\end{array}$ & $* *$ & $\begin{array}{c}0.031 \\
(0.006)\end{array}$ \\
\hline Azerbaijan & 2 & & & & & & & & & & & & & $\begin{array}{l}-0.066 \\
(0.010)\end{array}$ & $* *$ & \\
\hline Bangladesh & 3 & $\begin{array}{c}0.034 \\
(0.004)\end{array}$ & $\begin{array}{l}-0.003 \\
(0.005)\end{array}$ & & $\begin{array}{l}-0.018 \\
(0.001)\end{array}$ & $* *$ & $\begin{array}{l}-0.020 \\
(0.005)\end{array}$ & & $\begin{array}{l}-0.027 \\
(0.015)\end{array}$ & & $\begin{array}{l}-0.037 \\
(0.014)\end{array}$ & & $\begin{array}{l}-0.038 \\
(0.009)\end{array}$ & $\begin{array}{c}0.000 \\
(0.029)\end{array}$ & & $\begin{array}{c}0.006 \\
(0.008)\end{array}$ \\
\hline Belarus & 3 & & & & & & & & & & & & & $\begin{array}{l}-0.009 \\
(0.005)\end{array}$ & & \\
\hline Bolivia & 2 & $\begin{array}{c}0.057 \\
(0.006)\end{array}$ & $\begin{array}{c}0.030 \\
(0.009)\end{array}$ & $* *$ & $\begin{array}{l}-0.022 \\
(0.024)\end{array}$ & & $\begin{array}{c}0.011 \\
(0.023)\end{array}$ & & $\begin{array}{c}0.035 \\
(0.041)\end{array}$ & & $\begin{array}{c}0.026 \\
(0.030)\end{array}$ & & $\begin{array}{c}0.041 \\
(0.024)\end{array}$ & $\begin{array}{l}-0.003 \\
(0.023)\end{array}$ & & $\begin{array}{c}0.002 \\
(0.001)\end{array}$ \\
\hline Bosnia and Herzegovina & 2 & & & & & & & & & & & & & $\begin{array}{c}0.007 \\
(0.007)\end{array}$ & & \\
\hline Bosnia and Herzegovina & 3 & & & & & & & & & & & & & $\begin{array}{c}0.016 \\
(0.014)\end{array}$ & & \\
\hline Dominican Republic & 2 & $\begin{array}{c}0.084 \\
(0.008)\end{array}$ & $\begin{array}{c}0.018 \\
(0.012)\end{array}$ & & $\begin{array}{c}0.013 \\
(0.037)\end{array}$ & & $\begin{array}{c}0.033 \\
(0.042)\end{array}$ & & $\begin{array}{l}-0.128 \\
(0.056)\end{array}$ & & $\begin{array}{c}-0.062 \\
(0.070)\end{array}$ & & $\begin{array}{c}0.025 \\
(0.029)\end{array}$ & $\begin{array}{c}0.023 \\
(0.022)\end{array}$ & & $\begin{array}{c}0.005 \\
(0.009)\end{array}$ \\
\hline Georgia & 3 & & & & & & & & & & & & & $\begin{array}{l}-0.029 \\
(0.005)\end{array}$ & $* *$ & \\
\hline Guyana & 2 & & & & & & & & & & & & & $\begin{array}{l}-0.074 \\
(0.012)\end{array}$ & $* *$ & \\
\hline Guyana & 3 & & & & & & & & & & & & & $\begin{array}{c}-0.031 \\
(0.015)\end{array}$ & & \\
\hline Iraq & 2 & $\begin{array}{c}0.024 \\
(0.005)\end{array}$ & $\begin{array}{l}-0.006 \\
(0.005)\end{array}$ & & $\begin{array}{l}-0.005 \\
(0.007)\end{array}$ & & $\begin{array}{l}-0.016 \\
(0.012)\end{array}$ & & $\begin{array}{l}-0.030 \\
(0.026)\end{array}$ & & $\begin{array}{l}-0.027 \\
(0.025)\end{array}$ & & $\begin{array}{l}-0.033 \\
(0.028)\end{array}$ & $\begin{array}{l}-0.015 \\
(0.009)\end{array}$ & & $\begin{array}{c}0.002 \\
(0.003)\end{array}$ \\
\hline Iraq & 3 & $\begin{array}{c}0.016 \\
(0.002)\end{array}$ & $\begin{array}{c}0.006 \\
(0.002)\end{array}$ & $*$ & $\begin{array}{c}0.001 \\
(0.017)\end{array}$ & & $\begin{array}{c}0.007 \\
(0.020)\end{array}$ & & $\begin{array}{l}-0.010 \\
(0.025)\end{array}$ & & $\begin{array}{l}-0.008 \\
(0.028)\end{array}$ & & $\begin{array}{c}0.000 \\
(0.030)\end{array}$ & $\begin{array}{l}-0.017 \\
(0.002)\end{array}$ & * & $\begin{array}{l}0.017 \\
(0.005)\end{array}$ \\
\hline Jamaica & 3 & $\begin{array}{c}0.016 \\
(0.005)\end{array}$ & $\begin{array}{c}0.001 \\
(0.006)\end{array}$ & & $\begin{array}{l}-0.062 \\
(0.013)\end{array}$ & & $\begin{array}{l}-0.069 \\
(0.024)\end{array}$ & & $\begin{array}{l}-0.021 \\
(0.013)\end{array}$ & & $\begin{array}{l}-0.027 \\
(0.011)\end{array}$ & & $\begin{array}{l}-0.018 \\
(0.011)\end{array}$ & $\begin{array}{l}-0.005 \\
(0.005)\end{array}$ & & $\begin{array}{c}0.002 \\
(0.003)\end{array}$ \\
\hline
\end{tabular}


Table 7B: Changes in Time Allocation at the Age of Relaxation of Compulsory Schooling Laws, Non-Africa

\begin{tabular}{|c|c|c|c|c|c|c|c|c|c|c|c|c|c|c|c|c|c|c|}
\hline Country & $\begin{array}{c}\text { MICS } \\
\text { Rnd }\end{array}$ & $\begin{array}{c}\text { Paid Em } \\
\text { Base }\end{array}$ & $\begin{array}{l}\text { loyment } \\
\text { Change }\end{array}$ & & $\begin{array}{c}\text { Unpaid } \\
\text { Economic } \\
\text { Activity }\end{array}$ & & $\begin{array}{c}\text { Economic } \\
\text { Activity }\end{array}$ & & $\begin{array}{c}\text { Unpaid } \\
\text { Hh. } \\
\text { Services }\end{array}$ & & $\begin{array}{c}\text { Hh. Based } \\
\text { EA \& } \\
\text { Services }\end{array}$ & & $\begin{array}{c}\text { Any } \\
\text { Work }\end{array}$ & & $\begin{array}{l}\text { Attend } \\
\text { School } \\
\end{array}$ & & Idle & \\
\hline Kyrgyzstan & 3 & $\begin{array}{c}0.003 \\
(0.001)\end{array}$ & $\begin{array}{c}-0.003 \\
(0.002)\end{array}$ & & $\begin{array}{c}0.039 \\
(0.016)\end{array}$ & $*$ & $\begin{array}{c}0.038 \\
(0.019)\end{array}$ & $*$ & $\begin{array}{c}1.886 \\
(0.330)\end{array}$ & ** & $\begin{array}{c}1.888 \\
(0.331)\end{array}$ & ** & $\begin{array}{c}1.881 \\
(0.337)\end{array}$ & ** & $\begin{array}{l}-0.087 \\
(0.020)\end{array}$ & $* *$ & $\begin{array}{c}0.017 \\
(0.008)\end{array}$ & * \\
\hline Lao PDR & 2 & $\begin{array}{c}0.017 \\
(0.002)\end{array}$ & $\begin{array}{l}-0.001 \\
(0.003)\end{array}$ & & $\begin{array}{l}-0.010 \\
(0.022)\end{array}$ & & $\begin{array}{l}-0.020 \\
(0.018)\end{array}$ & & $\begin{array}{l}-0.045 \\
(0.003)\end{array}$ & $* *$ & $\begin{array}{l}-0.052 \\
(0.000)\end{array}$ & $* *$ & $\begin{array}{l}-0.055 \\
(0.003)\end{array}$ & $*$ & $\begin{array}{l}-0.046 \\
(0.080)\end{array}$ & & $\begin{array}{c}0.035 \\
(0.042)\end{array}$ & \\
\hline Lao PDR & 3 & $\begin{array}{c}0.014 \\
(0.009)\end{array}$ & $\begin{array}{c}0.001 \\
(0.011)\end{array}$ & & $\begin{array}{l}-0.008 \\
(0.042)\end{array}$ & & $\begin{array}{l}-0.004 \\
(0.051)\end{array}$ & & $\begin{array}{l}-0.003 \\
(0.024)\end{array}$ & & $\begin{array}{c}0.000 \\
(0.020)\end{array}$ & & $\begin{array}{c}0.002 \\
(0.016)\end{array}$ & & $\begin{array}{l}-0.029 \\
(0.085)\end{array}$ & & $\begin{array}{c}0.011 \\
(0.017)\end{array}$ & \\
\hline Macedonia & 3 & & & & & & & & & & & & & & $\begin{array}{l}-0.191 \\
(0.024)\end{array}$ & ** & & \\
\hline Moldova & 2 & & & & & & & & & & & & & & $\begin{array}{l}-0.123 \\
(0.012)\end{array}$ & $* *$ & & \\
\hline Mongolia & 2 & $\begin{array}{l}-0.003 \\
(0.006)\end{array}$ & $\begin{array}{c}0.027 \\
(0.006)\end{array}$ & $* *$ & $\begin{array}{l}-0.058 \\
(0.015)\end{array}$ & ** & $\begin{array}{l}-0.049 \\
(0.014)\end{array}$ & $* *$ & $\begin{array}{l}-0.001 \\
(0.015)\end{array}$ & & $\begin{array}{c}0.008 \\
(0.014)\end{array}$ & & $\begin{array}{c}0.005 \\
(0.016)\end{array}$ & & $\begin{array}{l}-0.171 \\
(0.080)\end{array}$ & * & $\begin{array}{l}-0.001 \\
(0.008)\end{array}$ & \\
\hline Mongolia & 3 & $\begin{array}{c}0.010 \\
(0.003)\end{array}$ & $\begin{array}{c}0.016 \\
(0.005)\end{array}$ & $* *$ & $\begin{array}{c}0.011 \\
(0.016)\end{array}$ & & $\begin{array}{l}0.018 \\
(0.014)\end{array}$ & & $\begin{array}{l}-0.068 \\
(0.014)\end{array}$ & $* *$ & $\begin{array}{l}-0.062 \\
(0.012)\end{array}$ & $* *$ & $\begin{array}{l}-0.055 \\
(0.013)\end{array}$ & $* *$ & $\begin{array}{l}-0.020 \\
(0.035)\end{array}$ & & $\begin{array}{c}0.010 \\
(0.004)\end{array}$ & ** \\
\hline Montenegro & 3 & & & & & & & & & & & & & & $\begin{array}{l}-0.028 \\
(0.008)\end{array}$ & $* *$ & & \\
\hline Philippines & 2 & $\begin{array}{c}0.052 \\
(0.005)\end{array}$ & $\begin{array}{l}-0.005 \\
(0.007)\end{array}$ & & $\begin{array}{c}0.009 \\
(0.017)\end{array}$ & & $\begin{array}{c}-0.002 \\
(0.024)\end{array}$ & & $\begin{array}{c}0.055 \\
(0.037)\end{array}$ & & $\begin{array}{c}0.063 \\
(0.032)\end{array}$ & & $\begin{array}{l}-0.008 \\
(0.031)\end{array}$ & & $\begin{array}{c}0.023 \\
(0.014)\end{array}$ & & $\begin{array}{c}0.002 \\
(0.004)\end{array}$ & \\
\hline Serbia & 3 & & & & & & & & & & & & & & $\begin{array}{l}-0.004 \\
(0.006)\end{array}$ & & & \\
\hline Suriname & 3 & $\begin{array}{c}0.035 \\
(0.006)\end{array}$ & $\begin{array}{c}-0.012 \\
(0.008)\end{array}$ & & $\begin{array}{l}-0.029 \\
(0.009)\end{array}$ & & $\begin{array}{l}-0.017 \\
(0.005)\end{array}$ & $*$ & $\begin{array}{l}-0.034 \\
(0.032)\end{array}$ & & $\begin{array}{l}-0.035 \\
(0.028)\end{array}$ & & $\begin{array}{l}-0.039 \\
(0.030)\end{array}$ & & $\begin{array}{c}0.021 \\
(0.018)\end{array}$ & & $\begin{array}{l}-0.010 \\
(0.003)\end{array}$ & * \\
\hline Syria & 3 & & & & & & & & & & & & & & $\begin{array}{c}0.126 \\
(0.027)\end{array}$ & $* *$ & & \\
\hline Tajikistan & 2 & & & & & & & & & & & & & & $\begin{array}{l}-0.038 \\
(0.023)\end{array}$ & & & \\
\hline Tajikistan & 3 & & & & & & & & & & & & & & $\begin{array}{l}-0.080 \\
(0.023)\end{array}$ & ** & & \\
\hline Thailand & 3 & & & & & & & & & & & & & & $\begin{array}{c}0.013 \\
(0.008)\end{array}$ & & & \\
\hline
\end{tabular}


Table 7B: Changes in Time Allocation at the Age of Relaxation of Compulsory Schooling Laws, Non-Africa

\begin{tabular}{|c|c|c|c|c|c|c|c|c|c|c|c|c|c|}
\hline Country & $\begin{array}{c}\text { MICS } \\
\text { Rnd }\end{array}$ & $\begin{array}{c}\text { Paid Em } \\
\text { Base }\end{array}$ & $\begin{array}{c}\text { ployment } \\
\text { Change }\end{array}$ & & $\begin{array}{l}\text { Unpaid } \\
\text { Economic } \\
\text { Activity }\end{array}$ & & $\begin{array}{c}\text { Economic } \\
\text { Activity }\end{array}$ & & $\begin{array}{c}\text { Unpaid } \\
\text { Hh. } \\
\text { Services }\end{array}$ & $\begin{array}{c}\text { Hh. Based } \\
\text { EA \& } \\
\text { Services } \\
\end{array}$ & $\begin{array}{c}\text { Any } \\
\text { Work }\end{array}$ & $\begin{array}{l}\text { Attend } \\
\text { School }\end{array}$ & Idle \\
\hline Trinidad and Tobago & 2 & $\begin{array}{c}0.061 \\
(0.003)\end{array}$ & $\begin{array}{c}-0.040 \\
(0.003)\end{array}$ & ** & $\begin{array}{c}-0.022 \\
(0.006)\end{array}$ & * & $\begin{array}{l}-0.031 \\
(0.010)\end{array}$ & * & $\begin{array}{l}-0.071 \\
(0.118)\end{array}$ & $\begin{array}{l}-0.073 \\
(0.109)\end{array}$ & $\begin{array}{l}-0.082 \\
(0.109)\end{array}$ & $\begin{array}{l}-0.007 \\
(0.004)\end{array}$ & \\
\hline Trinidad and Tobago & 3 & $\begin{array}{c}0.009 \\
(0.001)\end{array}$ & $\begin{array}{c}0.001 \\
(0.002)\end{array}$ & & $\begin{array}{c}0.027 \\
(0.009)\end{array}$ & $*$ & $\begin{array}{c}0.028 \\
(0.008)\end{array}$ & $*$ & $\begin{array}{c}0.011 \\
(0.023)\end{array}$ & $\begin{array}{l}0.020 \\
(0.025)\end{array}$ & $\begin{array}{c}0.023 \\
(0.025)\end{array}$ & $\begin{array}{l}-0.002 \\
(0.007)\end{array}$ & $\begin{array}{l}-0.005 \\
(0.004)\end{array}$ \\
\hline Venezuela & 2 & $\begin{array}{c}0.168 \\
(0.011)\end{array}$ & $\begin{array}{c}0.097 \\
(0.014)\end{array}$ & $* *$ & $\begin{array}{c}0.039 \\
(0.027)\end{array}$ & & $\begin{array}{c}0.141 \\
(0.033)\end{array}$ & $* *$ & $\begin{array}{c}0.015 \\
(0.018)\end{array}$ & $\begin{array}{l}-0.008 \\
(0.021)\end{array}$ & $\begin{array}{c}0.026 \\
(0.028)\end{array}$ & $\begin{array}{c}0.036 \\
(0.033)\end{array}$ & $\begin{array}{l}-0.006 \\
(0.009)\end{array}$ \\
\hline Vietnam & 2 & $\begin{array}{c}0.071 \\
(0.010)\end{array}$ & $\begin{array}{c}0.018 \\
(0.012)\end{array}$ & & $\begin{array}{l}-0.087 \\
(0.019)\end{array}$ & ** & $\begin{array}{l}-0.055 \\
(0.018)\end{array}$ & $* *$ & $\begin{array}{l}-0.038 \\
(0.029)\end{array}$ & $\begin{array}{c}0.019 \\
(0.044)\end{array}$ & $\begin{array}{l}-0.021 \\
(0.031)\end{array}$ & $\begin{array}{c}0.036 \\
(0.028)\end{array}$ & $\begin{array}{l}-0.005 \\
(0.009)\end{array}$ \\
\hline Vietnam & 3 & & & & & & & & & & & $\begin{array}{c}-0.077 \\
(0.006)\end{array}$ & \\
\hline Yemen & 3 & & & & & & & & & & & $\begin{array}{c}0.024 \\
(0.036)\end{array}$ & \\
\hline
\end{tabular}

Age cell level regressions. Standard errors in parenthesis. * significant at 10\%. ** Significant at 5\%. 
Table 8: Changes in Time Allocation with Relaxation of Minimum Age Restrictions by Compulsory Schooling Status, All Countries Pooled

\begin{tabular}{|c|c|c|c|c|c|c|c|c|c|}
\hline Compulsory Schooling Status & $\begin{array}{l}\text { Paid Em } \\
\text { Base }\end{array}$ & $\begin{array}{l}\text { ployment } \\
\text { Change }\end{array}$ & $\begin{array}{l}\text { Unpaid } \\
\text { Economic } \\
\text { Activity }\end{array}$ & $\begin{array}{l}\text { Economic } \\
\text { Activity }\end{array}$ & $\begin{array}{l}\text { Unpaid } \\
\text { Hh. } \\
\text { Services }\end{array}$ & $\begin{array}{c}\text { Hh. Based } \\
\text { EA \& } \\
\text { Services }\end{array}$ & $\begin{array}{l}\text { Any } \\
\text { Work }\end{array}$ & $\begin{array}{l}\text { Attend } \\
\text { School }\end{array}$ & Idle \\
\hline $\begin{array}{l}\text { Schooling is not Compulsory at } \\
\text { Minimum Age of Employment }\end{array}$ & $\begin{array}{l}0.068 \\
(0.005)\end{array}$ & $\begin{array}{l}-0.002 \\
(0.007)\end{array}$ & $\begin{array}{l}-0.040 \\
(0.057)\end{array}$ & $\begin{array}{l}-0.026 \\
(0.059)\end{array}$ & $\begin{array}{c}0.018 \\
(0.059)\end{array}$ & $\begin{array}{l}-0.050 \\
(0.057)\end{array}$ & $\begin{array}{c}-0.042 \\
(0.056)\end{array}$ & $\begin{array}{c}0.000 \\
(0.039)\end{array}$ & $\begin{array}{l}-0.010 \\
(0.029)\end{array}$ \\
\hline
\end{tabular}

Schooling Stops Being

\begin{tabular}{lccccccccc} 
Compulsory at Minimum Age of & 0.056 & 0.018 & $* *$ & 0.011 & 0.022 & 0.084 & 0.088 & 0.082 & -0.073 \\
Employment & $(0.004)$ & $(0.004)$ & $(0.048)$ & $(0.047)$ & $(0.073)$ & $(0.063)$ & $(0.059)$ & $(0.061)$ & $(0.019)$ \\
\hline \hline
\end{tabular}

Change in column variable at age of relaxation of minimum age of employment regulation. Age cell level regressions. Each cell weighted by All countries pooled. 
Appendix Table 1: Changes in Time Allocation at the Age of Relaxation of Minimum Age Laws (Light Work), Methods Comparison

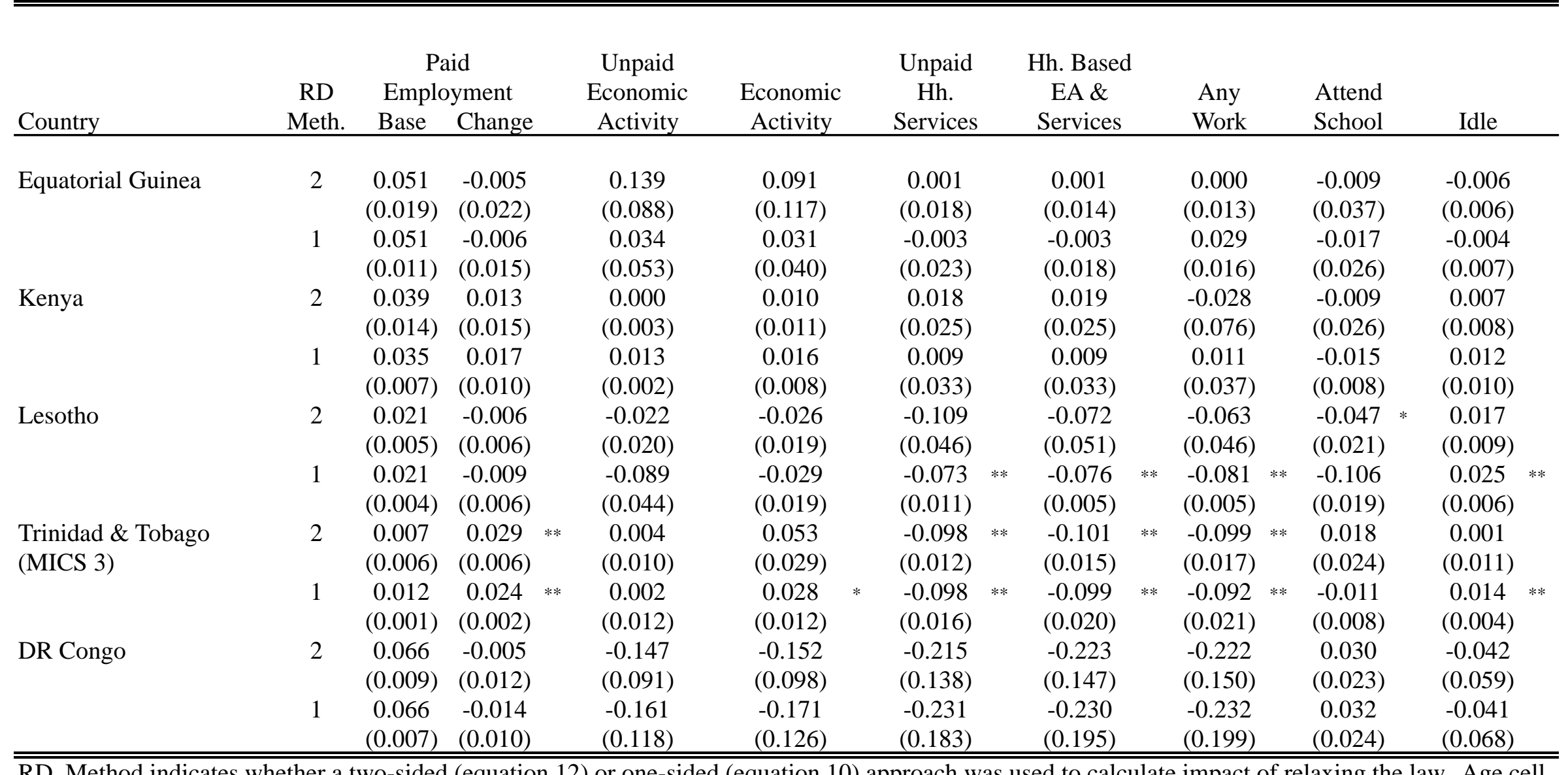

RD. Method indicates whether a two-sided (equation 12) or one-sided (equation 10) approach was used to calculate impact of relaxing the law. Age cell level regressions. Standard errors in parenthesis. * significant at $10 \%$. ** Significant at $5 \%$. 


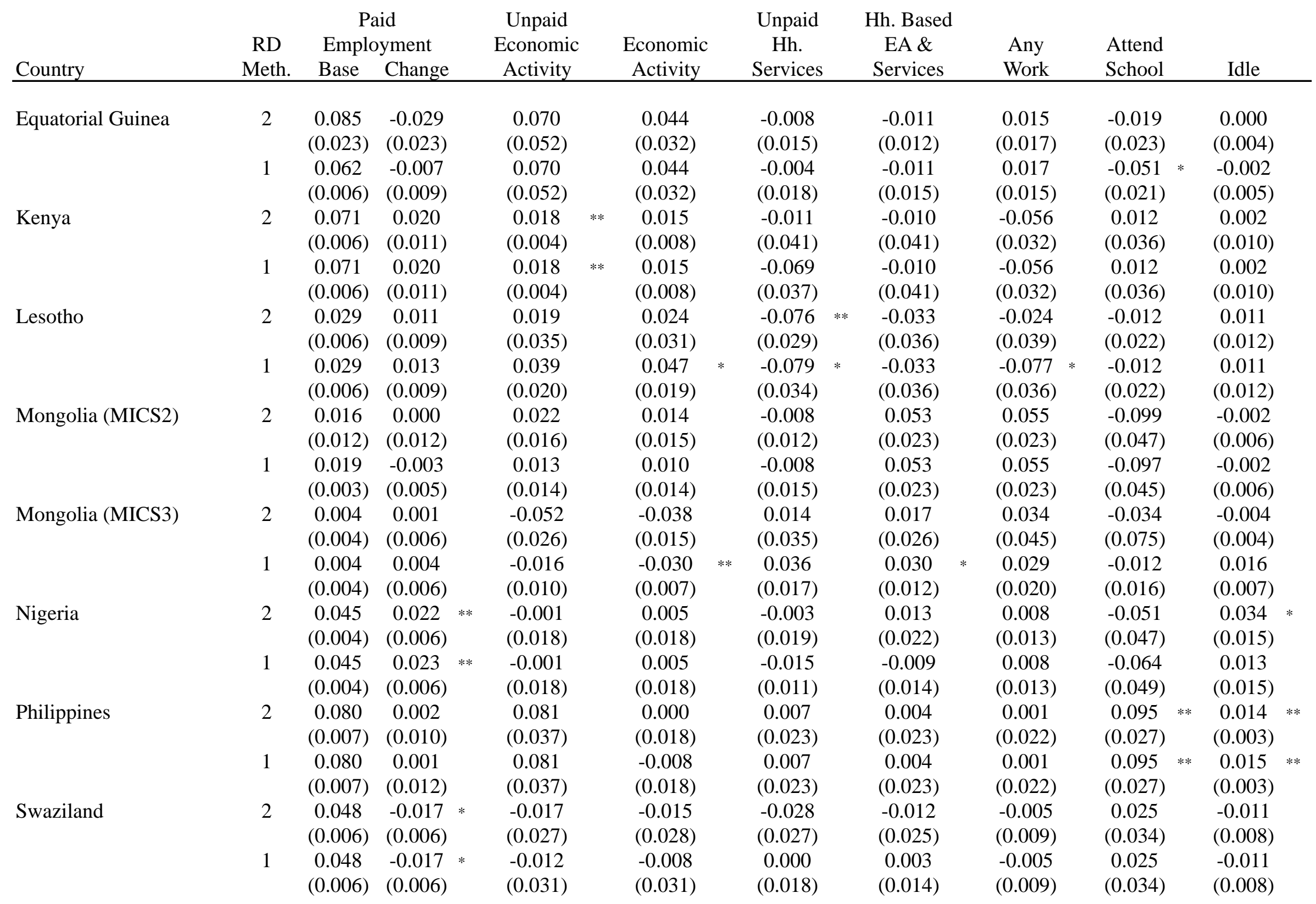


Appendix Table 2: Changes in Time Allocation at the Age of Relaxation of Minimum Age Laws Non-Hazardous Work), Methods Comparison

\begin{tabular}{|c|c|c|c|c|c|c|c|c|c|c|c|c|c|c|}
\hline Country & $\begin{array}{l}\text { RD } \\
\text { Meth. }\end{array}$ & $\begin{array}{r}\mathrm{P} \\
\text { Empl } \\
\text { Base }\end{array}$ & $\begin{array}{l}\text { id } \\
\text { yment } \\
\text { Change }\end{array}$ & & $\begin{array}{c}\text { Unpaid } \\
\text { Economic } \\
\text { Activity }\end{array}$ & & $\begin{array}{c}\text { Economic } \\
\text { Activity }\end{array}$ & & $\begin{array}{l}\text { Unpaid } \\
\text { Hh. } \\
\text { Services }\end{array}$ & $\begin{array}{c}\text { Hh. Based } \\
\text { EA \& } \\
\text { Services }\end{array}$ & $\begin{array}{c}\text { Any } \\
\text { Work }\end{array}$ & $\begin{array}{l}\text { Attend } \\
\text { School }\end{array}$ & & Idle \\
\hline \multirow[t]{4}{*}{ Togo (MICS2) } & 2 & 0.218 & 0.004 & & 0.093 & $* *$ & 0.065 & & 0.028 & 0.024 & 0.030 & 0.007 & & -0.010 \\
\hline & & $(0.023)$ & $(0.032)$ & & $(0.024)$ & & $(0.039)$ & & $(0.022)$ & $(0.012)$ & $(0.017)$ & $(0.021)$ & & $(0.013)$ \\
\hline & 1 & 0.218 & -0.009 & & 0.092 & $* *$ & 0.066 & & 0.024 & 0.022 & 0.028 & 0.003 & & -0.008 \\
\hline & & $(0.023)$ & $(0.035)$ & & $(0.027)$ & & $(0.045)$ & & $(0.011)$ & $(0.008)$ & $(0.015)$ & $(0.013)$ & & $(0.012)$ \\
\hline \multirow[t]{4}{*}{ Trinidad \& Tobago (MIC } & 2 & 0.026 & 0.035 & $* *$ & 0.002 & & 0.030 & * & 0.100 & 0.114 & 0.122 & -0.055 & $* *$ & $-0.020 *$ \\
\hline & & $(0.007)$ & $(0.011)$ & & $(0.009)$ & & $(0.015)$ & & $(0.052)$ & $(0.054)$ & $(0.049)$ & $(0.012)$ & & $(0.008)$ \\
\hline & 1 & 0.026 & 0.035 & $* *$ & 0.002 & & 0.030 & $*$ & 0.100 & 0.114 & 0.122 & -0.067 & $* *$ & $-0.020 *$ \\
\hline & & $(0.007)$ & $(0.011)$ & & $(0.009)$ & & $(0.015)$ & & $(0.052)$ & $(0.054)$ & $(0.049)$ & $(0.008)$ & & $(0.008)$ \\
\hline \multirow[t]{4}{*}{ Venezuela } & 2 & 0.124 & -0.044 & & 0.097 & $* *$ & 0.031 & & 0.006 & 0.028 & 0.068 & -0.007 & & 0.012 \\
\hline & & $(0.024)$ & $(0.025)$ & & $(0.029)$ & & $(0.086)$ & & $(0.015)$ & $(0.020)$ & $(0.043)$ & $(0.136)$ & & $(0.008)$ \\
\hline & 1 & 0.097 & -0.018 & & 0.061 & $*$ & 0.071 & $* *$ & 0.004 & 0.025 & 0.041 & -0.018 & * & 0.010 \\
\hline & & $(0.013)$ & $(0.015)$ & & $(0.023)$ & & $(0.025)$ & & $(0.013)$ & $(0.019)$ & $(0.022)$ & $(0.007)$ & & $(0.010)$ \\
\hline \multirow[t]{4}{*}{ DR Congo } & 2 & 0.085 & -0.006 & & 0.086 & & 0.082 & & 0.116 & 0.126 & 0.125 & -0.002 & & -0.053 \\
\hline & & (0.007) & $(0.011)$ & & $(0.120)$ & & $(0.130)$ & & $(0.170)$ & $(0.180)$ & $(0.184)$ & $(0.021)$ & & $(0.057)$ \\
\hline & 1 & 0.085 & -0.006 & & 0.086 & & 0.082 & & 0.116 & 0.126 & 0.125 & -0.002 & & -0.053 \\
\hline & & $(0.007)$ & $(0.011)$ & & $(0.120)$ & & $(0.130)$ & & $(0.170)$ & $(0.180)$ & $(0.184)$ & $(0.021)$ & & $(0.057)$ \\
\hline
\end{tabular}

$\overline{\text { RD. Method indicates whether a two-sided (equation 12) or one-sided (equation 10) approach was used to calculate impact of relaxing the law. Age cell }}$ level regressions. Standard errors in parenthesis. * significant at $10 \%$. ** Significant at $5 \%$. 